Mexican Journal of Biotechnology 2021, 6(1):31-91

Journal homepage:www.mexjbiotechnol.com

Research Centre for Biological Sciences

(CICB), Autonomous University of

Tlaxcala, Mexico. All rights reserved

ISSN:2448-6590

REVIEW ARTICLE

\title{
Saving the planet with appropriate biotechnology: 2. Cultivate shellfish to remediate the atmosphere
}

\section{Salvando el planeta con biotecnología apropiada: 2. Cultivar mariscos para remediar la atmósfera}

David Moore ${ }^{1 *}$, Matthias Heilweck ${ }^{2} \&$ Peter Petros ${ }^{3}$

${ }^{1}$ School of Biological Sciences, Faculty of Biology, Medicine and Health, The University of Manchester, UK (retired).

23, place Gouraud, F-68240 Kaysersberg, France [http://www.commonseagood.com/].

${ }^{3}$ Kääpä Biotech Oy, Teilinummentie 4, 09120 Karjalohja, Finland.

${ }^{*}$ Corresponding author

E-mail address: david@davidmoore.org.uk (D. Moore)

Article history:

Received: 12 October 2020 / Received in revised form: 10 December 2020 / Accepted: / 23 December 2020 / Published online: 1 January 2021.

https://doi.org/10.29267/mxib.2021.6.1.31

\begin{abstract}
Shellfish cultivation is the only industry on the planet that (a) feeds us, (b) permanently removes $\mathrm{CO}_{2}$ from our atmosphere, and, with care, could (c) engineer our marine habitats to maintain the health and biodiversity of those ecosystems into the future. About $30-50 \%$ of shellfish biomass is represented by the animals' shells, and shellfish shell is made by converting atmospheric $\mathrm{CO}_{2}$ into crystalline calcium carbonate which is stable for geological periods of time. The human tradition of eating shellfish is recorded in the ancient middens of shellfish shells that track migrations of early humans around the world. Recent history shows increasing exploitation of marine resources by an ever-growing human population. By the end of the 19th century oysters had become a cheap staple food on both sides of the Atlantic, but this oyster dredging destroyed $85 \%$ of the world's oyster beds. In the tropics, Giant Clams have also been fished to extinction in many Indian Ocean and Pacific waters. In the 21 st century, these animals deserve to have the same vigour applied to their restoration and conservation as we applied to dredging them from the seabed. In return they will cleanse our atmosphere by permanently sequestering its excess $\mathrm{CO}_{2}$ into limestone. And we must start now, before Homo sapiens is added to the list of organisms driven to extinction by humanity's follies.
\end{abstract}

Keywords: aquaculture, atmosphere remediation, bivalve farm, carbon dioxide, global warming, habitat restoration. 


\section{RESUMEN}

El cultivo de mariscos es la única industria en el planeta que (a) nos alimenta, (b) elimina permanentemente el $\mathrm{CO}_{2}$ de nuestra atmósfera y, con cuidado, podría (c) diseñar nuestros hábitats marinos para mantener la salud y la biodiversidad de esos ecosistemas en el futuro. Alrededor del $30-50 \%$ de la biomasa de mariscos está representada por las conchas de los animales, y la cubierta de los mariscos se hace mediante la conversión de $\mathrm{CO}_{2}$ atmosférico en carbonato de calcio cristalino que es estable durante períodos geológicos de tiempo. La tradición humana de comer mariscos se registra en los antiguos concheros de mariscos que rastrean las migraciones de los primeros seres humanos en todo el mundo. La historia reciente muestra una explotación cada vez mayor de los recursos marinos por parte de una población humana en constante crecimiento. A finales del siglo XIX, las ostras se habían convertido en un alimento básico barato en ambos lados del Atlántico, pero el dragado de ostras destruyó el 85\% de los yacimientos de ostras del mundo. En los trópicos, las almejas gigantes también han sido pescadas hasta la extinción en muchas aguas del Océano Indico y el Pacífico. En el siglo XXI, estos animales merecen que se les aplique el mismo grado de intensidad en apoyo a su restauración y conservación que el que se aplica para dragarlos del fondo marino. A cambio limpiarán nuestra atmósfera secuestrando permanentemente el exceso de $\mathrm{CO}_{2}$ en piedra caliza. Y debemos empezar ahora, antes de que el Homo sapiens se añada a la lista de organismos impulsados a la extinción por la insensatez humana.

Palabras clave: acuicultura, remediación de la atmósfera, cultivo de bivalvo, dióxido de carbono, calentamiento global, restauración del hábitat.

\section{Cultivate shellfish: Save the atmosphere}

There are four interesting and readily verifiable facts about shellfish that are relevant to this discussion, which we will examine in turn.

- There's a lot of shell in shellfish.

- $\quad$ Shellfish shell is mineralised carbon dioxide from the atmosphere.

- Shellfish shell is not digested and is chemically stable for geological periods of time.

- The shellfish cultivation industry is the only industry on Earth that can be greatly expanded, relatively cheaply, and can be guaranteed to limit climate change and enhance conservation.

Many of us enjoy shellfish foods, especially cockles (clams), mussels, prawns, crab and lobster, and all the other seaside treats, too. So, we must all be aware of the amount of shell left over after the meal.

Figs 1 and 2 illustrate two different shellfish meals for two: just under a kilo of mussels, and just under a kilo of cockles, the leftover shells from which weigh in at $853 \mathrm{~g}$, which is $48 \%$ of the fresh weight of the shellfish. How does this relate to the global scale? Data from FAO Fisheries and Aquaculture Information and Statistics Branch (as of 25 May 2019) show that over the years 2010 to 2017 aquaculture harvests across the globe totalled 53,512,850 metric tonnes of crustaceans and 122,527,372 metric tonnes of molluscs (a combined total of 176,040,222 metric tonnes in 8 years (Table 1).

Figs 1 and 2 suggest that it's a reasonable guestimate that shell represents an average $50 \%$ of the animal's mass, so the total shellfish-shell produced was 88 million tonnes over 8 years. An average of $\mathbf{1 1}$ million tonnes of shell per year. If we further assume that the shell is made entirely from $\mathrm{CaCO}_{3}$; then, on a molar mass basis, carbon represents $12 \%$ of the mass of 
calcium carbonate. So, 11 million tonnes of shell per year is equivalent to 1.32 million tonnes of carbon per year being captured from the atmosphere by current aquaculture activities.

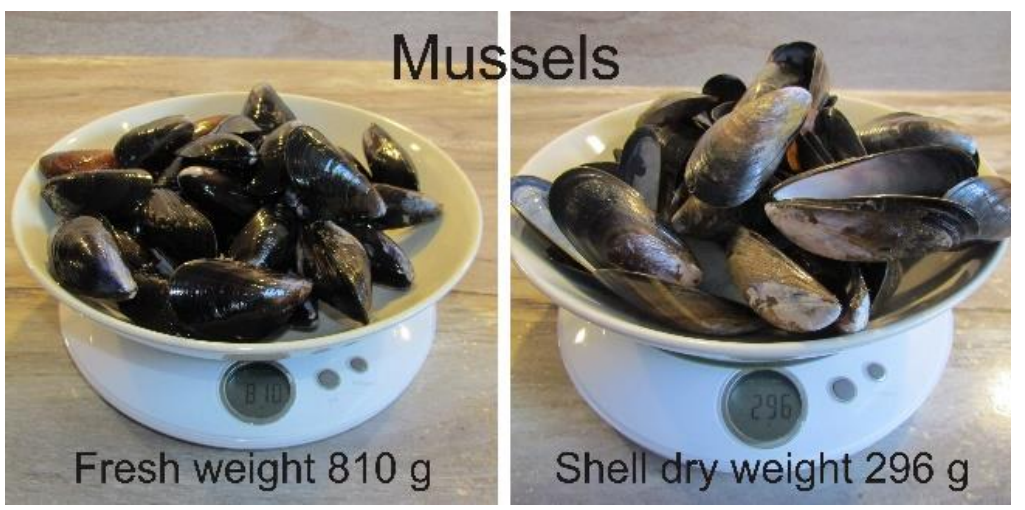

Fig. 1. Mussels: fresh $810 \mathrm{~g}$, shell dry weight $296 \mathrm{~g}=36.5 \%$ of the fresh mussel is shell. Photographs by David Moore.

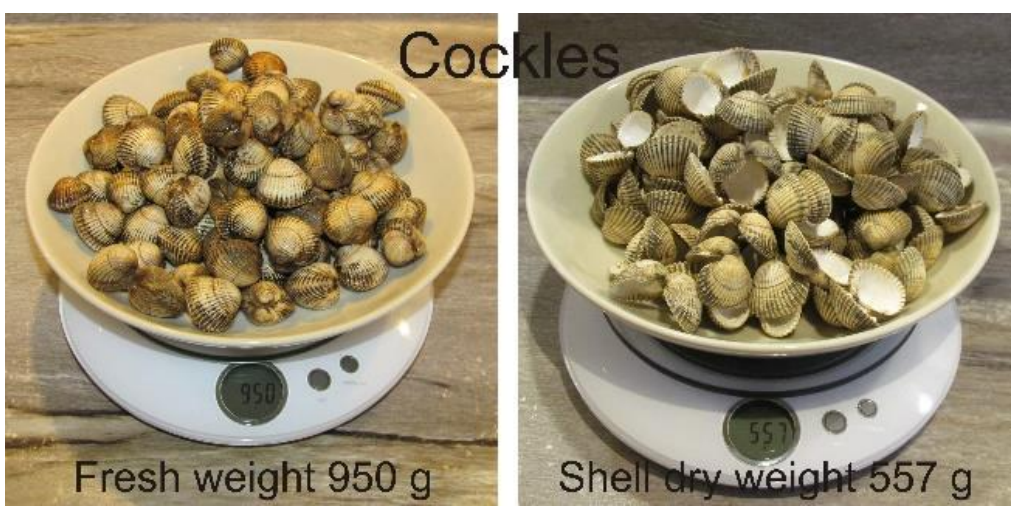

Fig. 2. Cockles (= Clams): fresh $950 \mathrm{~g}$. shell dry weight $557 \mathrm{~g}=$ $58.6 \%$ of the fresh cockle is shell. Photographs by David Moore.

Global carbon emissions from fossil fuel use were 9.8 billion tonnes in 2014 (equivalent to 35.9 billion tonnes of carbon dioxide) [source: https://www.co2.earth/global-co2-emissions]. So, a thousand-fold increase in today's aquaculture would permanently remove about $14 \%$ of the global carbon emissions in each year. Extrapolating the figures in Table 1 suggests that this year's global aquaculture farming will remove about 5.5 million tonnes of $\mathrm{CO}_{2}$ from the atmosphere. Biotechnological research on aquaculture is well established (e.g., Rasmussen \& Morrissey, 2007; Xiang, 2015); as is practical knowhow advice (Lovatelli, 1990; Utting \& Spencer, 1991; Helm et al., 2004).

A more unusual suggestion would be to cultivate coccolithophore algae in terrestrial ponds or even giant illuminated fermenters (see Moore, 2021); some species of these single-celled green algae coat their cells with plates of micro-crystalline $\mathrm{CaCO}_{3}$, which they shed during their growth. It has been demonstrated that each hectare $\left(10,000 \mathrm{~m}^{2}\right)$ of their pond cultivation could remove 0.66 tonnes of carbon (permanently) from the atmosphere each year (Moheimani \& Borowitzka, 2006). 
Table 1. Quantities of shellfish harvested across the globe in each specified year

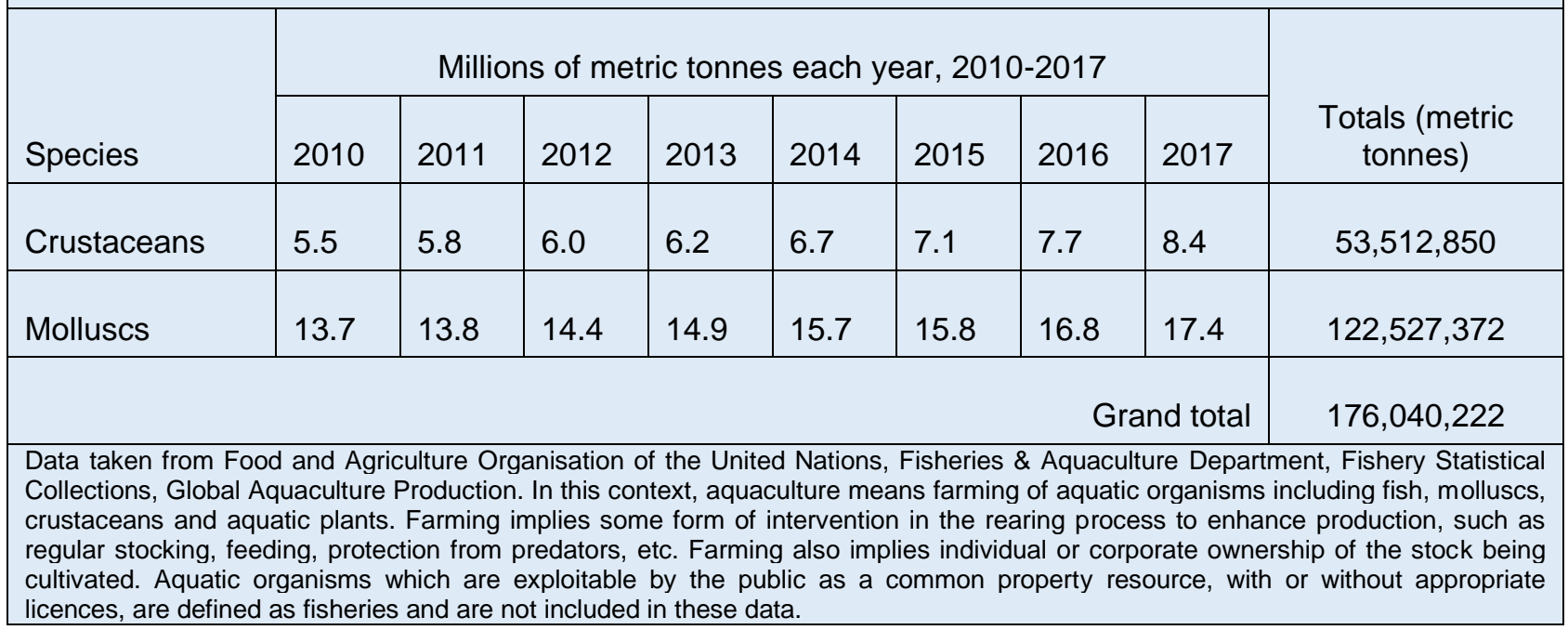

Could we increase shellfish production to a level that would achieve very significant sequestration of atmospheric $\mathrm{CO}_{2}$ ? Possibly. If we doubled aquaculture production of crustaceans and molluscs each year then from the 14th year we could be removing 10.7 billion tonnes of carbon from the atmosphere annually. Sustained annual doubling may not be realistic; but this simple calculation indicates that with determined effort (and adequate finance) to massively increase aquaculture production we could be permanently extracting significant amounts of carbon every year from the atmosphere within the timescale that is currently envisaged for carbon capture by afforestation.

Turn a quarter of UK [coastal] waters over to mussel farming and the shellfish would drawdown about an eighth of the UK's total emissions annually (source: Spanner Film's Pie Net Zero YouTube videos [at https://www.youtube.com/watch?v=rhA5LgXMBkw \& [https://www.youtube.com/watch?v=0-YuoWaCfhl].

\section{Shellfish shell is mineralised carbon dioxide from the atmosphere}

Molluscan shell is a biomineral composed of $\mathrm{CaCO}_{3}$ with a small amount of matrix proteins included, which are responsible in the live animal for directing the species-specific crystal growth. Arthropod (crab, shrimp, lobster) exoskeletons are composed largely of chitin but this is hardened by deposition of calcium-magnesium carbonate nanocrystals. In either group of organisms, shellfish shell is about $95 \%$ crystalline calcium carbonate. The animals make this by absorbing calcium through specific transporters in their tissues and reacting it with bicarbonate $\left(\mathrm{HCO}_{3}{ }^{-}\right.$), which is synthesised from $\mathrm{CO}_{2}$ (see Fig. 20 in Heilweck \& Moore, 2021). Some of the bicarbonate is absorbed directly from the surrounding water (or gaseous atmosphere for terrestrial species), the rest derives from $\mathrm{CO}_{2}$ generated from the animal's food. Of course, most of these animals are filter feeders; the $\mathrm{CO}_{2}$ generated by their metabolic cycles comes from digestion of plankton and is ultimately derived from planktonic photosynthesis (Tassanakajon et al., 2008). But since all food chains start with a photosynthetic producer organism that makes its own food, whatever the shellfish animal eats depends ultimately on fixation of photosynthetic carbon from the atmosphere. This is true of all the carbon in the food of predators, scavengers, filter-feeders and detritus feeders alike, aquatic and terrestrial. Globally, metabolic carbon is derived from photosynthetic fixation of atmospheric carbon; there is no other source. 
Bivalves constitute a substantial component of communities at and within the coastal sea floor. Among them, blue mussels, classified in the Mytilus species complex, are important foundation species throughout the temperate and polar littoral zones of the northern and southern hemispheres. "... Foundation species define ecosystems, control the biological diversity of associated species, modulate critical ecosystem processes, and often have important cultural values ..." (Ellison, 2019). The 'cultural value' of mussels, of course, is that they are a vital economic resource for the aquaculture industry (see references in Telesca et al., 2018).

The environment in which mussels (and other bivalves) grow affects the animals' growth patterns in a complex way, with several interacting factors resulting in a variety of shell shapes. Growing awareness of climate change and its consequences for biodiversity, especially of habitat-forming bivalve species, has prompted use of Mytilus spp. as model organisms for studying ecological and physiological responses to environmental conditions. Shell shape variability in bivalves is an important aspect of the animals' ability to adapt to environmental stresses, and understanding, and quantifying, environmental effects on shell shape will contribute to our understanding of how bivalve communities might react to ongoing climate change (Telesca et al., 2018; and references therein).

Since all environmental conditions vary in both time and space, wide variation in shell morphology is to be expected, even in animals from the same locality. In any one bivalve population, variation in shell form can be attributed to any or all of the following differences (Seed, 1968, 1980; Gimin et al., 2004; Telesca et al., 2018; and references therein):

- $\quad$ Temperature and food supply were the main drivers of mussel shape heterogeneity.

- Salinity had the strongest effect on the latitudinal geographic distribution of Mytilus shapes: lower salinities producing more elongated and narrower shells.

- Age also influences the shell; old mussels having proportionately heavier shells (in which width often exceeds shell height) than young mussels.

- Genotypic differences and hybridisation within the Mytilus edulis species-complex also influence shell variation.

- Population density coupled with population growth rate, which probably exert their effects through physical compression. This being maximal in localities of fast growth and high population density and least in areas of slow growth and low density. Compression (crowding) of mussels leads to an elongated shell form, while shells experiencing low crowding are more triangular in shape. Even in the same habitat, however, growth rates and population densities are very variable.

- Predation pressure influences changes in shell proportions and structure in mussels. Various species of aquatic birds are the main predators of mussels, some birds diving under water to take buried mussels, other predators are starfish and marine gastropods, such as the dog whelk, Nucella lapillus. In the Baltic Sea, mussels constitute $80-90 \%$ of the coastal animal biomass, this dominance is attributed to an almost complete absence of predators. Conversely, Northern Atlantic and Arctic Mytilus populations face predation pressures varying with latitude and competition for space (Telesca et al., 2018; and references therein).

Variability of shell shape is an adaptive feature allowing the animals to respond to less favourable environmental conditions. Food supply, temperature, and salinity have the greatest influence on this variability. In intertidal bivalves, shell weight is supported by a smaller biomass in animals located high on the shore than in those at the low water mark. A response determined by the need to provide space within the shell for filter feeding by the gills. Mussels respond to shorter feeding periods at higher shore levels by maximizing shell growth at the 
expense of body growth (although both are less than optimal) because gill area can be increased only by increasing shell length (Franz, 1993) and thicker and heavier shell valves than normal, that can be closed tightly to protect the body against adverse environmental conditions (and predators) have been reported in Mytilus edulis inhabiting periodically dry zones.

When the emersion is periodic, bivalves need to maintain a large volume of water inside the shell to create a sufficiently watery environment for survival of the body tissue. A low rate of tissue growth is a useful strategy for survival under prolonged exposure. If the soft tissue continued to grow steadily and come to occupy a large part of the space, then there would not be enough water inside the shell to support the metabolic needs of the increased tissue (Seed, 1968, 1980; Gimin et al., 2004).

\section{Shellfish shell is not digested and is chemically stable for geological periods of time}

Ultimately, then, the $\mathrm{CO}_{2}$ for the shell comes from the atmosphere and it stays out of the atmosphere, PERMANENTLY.

- Intact shellfish shells are excavated regularly from the middens associated with coastal communities of early humans (from around 120,000 years ago, see Section 7 below).

- Intact shellfish shells abound in deep-water cores of ancient coastal sediments of hundreds of thousands of years ago.

- And remember the fossils from deep time? Ammonites (65 to 240 million years ago), trilobites (520 million years ago), brachiopods (550 million years ago), shellfish all. Certainly, these fossil shells are changed considerably in chemistry by now (over extended time periods carbonates can recrystallise into calcite, or exchange with silica or iron sulphide in the surrounding rock matrix), but the shell carbonates survive over geological time. The carbonates in shells are neither digested nor degraded. High temperatures are required to release the $\mathrm{CO}_{2}$ from carbonates (to produce quicklime) - ask the cement industry, which uses fossiliferous limestone as a feedstock for cement production (cement production accounts for about $8 \%$ of the fossil $\mathrm{CO}_{2}$ emissions from industrial sources). The sedimentary limestone rocks derive their calcium carbonate from the biological activities of bryozoa, corals, crinoids, microscopic algae and shellfish shells. Even chemical precipitation, which is an important method by which limestones form, depends on solution of biologically-produced $\mathrm{CaCO}_{3}$ as water currents agitate grains of sand and shell fragments together. Warm, shallow waters can be saturated with $\mathrm{CaCO}_{3}$, which crystallises as aragonite on nuclei formed from shell fragments and builds up in concentric layers to form small multilayered spheres called ooids. In the natural world, the carbonates of shells are only likely to release their $\mathrm{CO}_{2}$ when/if they encounter volcanic conditions, or sink in the ocean deeps beneath the Carbonate Compensation Depth of about 5,000 m. How much more permanent, do we need permanent carbon sequestration to be?

\section{We Need to Change the Paradigm}

The principal contrast of shellfish shell with trees is that shellfish shell is mineralised and permanently solidified atmospheric $\mathrm{CO}_{2}$. Indeed, shellfish cultivation is the ONLY industry on the planet that currently removes serious quantities of carbon dioxide permanently from the atmosphere.

At present we cultivate shellfish for the meat (the shell is food-waste) and the industry is scaled according to that market. We must change the paradigm: cultivate the bivalves, and those 
other shellfish, to sequester permanently $\mathrm{CO}_{2}$ from the atmosphere and accept the food as a saleable by-product. Changing the paradigm means placing the value of the exercise of shellfish cultivation onto the production of shell, taking the food value of the animal protein as one of the peripheral or additional benefits (for which see next section).

There is a recently-published study of mussel cultivation economics that can be used to estimate the broad costs of the project(s) we are proposing. Avdelas et al. (2020) reported a decline in mussel aquaculture in the European Union (EU) in the first decades of the 21st century, contrasting with increasing aquaculture production of mussels worldwide. In attempting to analyse potential causes for this, these authors investigated the economics (across eight EU nations) of the different mussel production techniques (bouchot, on-bottom, raft, and longline; Table 2) and it is this aspect of their study we wish to use. In doing this we recognise that mussel production costs are highly variable, and that working with data averaged between different cultivation methods, which have different cost structures, and between different countries with different labour costs is not entirely satisfactory. Nevertheless, we believe that we can arrive at order-of-magnitude estimates this way.

Avdelas et al. (2020) provide a production cost (and farm gate sale price) for mussels produced by four different methods, averaged across the EU and across the years 2010 to 2016 (Table 2).

Table 2. Economics of mussel production in the EU over the years 2010-2016

\begin{tabular}{|l|c|c|c|c|}
\hline Production technique* & bouchot & on-bottom & raft & longline \\
\hline Number of enterprises & 338 & 96 & 2039 & 247 \\
\hline Production cost $\left(€ \mathrm{~kg}^{-1}\right)$ & 1.65 & 0.90 & 0.31 & 0.62 \\
\hline Farm gate price $\left(€ \mathrm{~kg}^{-1}\right)$ & 2.04 & 1.25 & 0.37 & 0.66 \\
\hline
\end{tabular}

*Data sourced from Table 1 in Avdelas et al. (2020), who consider these four production techniques: bouchot culture, also called pole or stake culture, uses poles (traditionally 4 to $6 \mathrm{~m}$ long trunks of oak trees) which are staked across the intertidal zone in rows, $0.7 \mathrm{~m}$ apart; mussel seeds are collected on ropes hung around the poles; bottom culture is growing mussels directly on the seabed; raft culture uses mussel seeds that settle on ('collection-') ropes suspended from a raft; and long-line culture has collection-ropes suspended from a long line which is supported by floats joined together by a cable or chain that is anchored at each end. These techniques are described more fully by Heilweck \& Moore (2021).

Table 2 shows that the overall average production cost of mussels in the EU over the years 2010-2016 was $0.87 € \mathrm{~kg}^{-1}$ (for a farm gate price of $1.08\left(€ \mathrm{~kg}^{-1}\right)$. Other useful data from the same source (Table 1 in Avdelas et al., 2020) are:

- $\quad$ the grand average value of assets per enterprise = approximately $€ 700,000$.

- $\quad$ the grand average turnover per enterprise = approximately $€ 384,000$.

- $\quad$ total number of enterprises listed in Table $1=2,720$.

Avdelas et al. (2020) also report that the eight EU countries they analysed produced 480,000 $\mathrm{t}$ of mussels in 2016 valued at $€ 328$ million. From these data, I calculate that the average EU mussel farming enterprise in 2016 produced an average of $176 \mathrm{t}$ of mussels valued at approximately $€ 121,000=€ 687.5 \mathrm{t}^{-1}=0.69\left(€ \mathrm{~kg}^{-1}\right)$. 
From these data, we can make the conservative estimate, therefore, that investment of $€ 1$ million could create a mussel production facility able to cultivate at least $250 \mathrm{t} \mathrm{y}^{-1}$ of mussels; the food value of which is approximately $€ 173,000$. But we are interested in shell production, so we calculate that $250 \mathrm{t} \mathrm{y}^{-1}$ of fresh mussels is approximately equivalent to $125 \mathrm{t}$ of shell, which is equivalent to $15 \mathrm{t}$ of carbon removed permanently from the atmosphere each year in those shells. Consequently, we can estimate that an investment of $€ 1$ billion could remove $15,000 \mathrm{t}$ carbon from the atmosphere each year.

Table 3. Forward projection of an investment, made in 2020 , of $€ 1$ billion in a mussel-shell production facility

\begin{tabular}{|c|c|c|c|}
\hline Year & $\begin{array}{c}\text { No. of Facilities } \\
\text { Financed }\end{array}$ & $\begin{array}{c}\text { Annual carbon } \\
\text { sequestration (Mt) }\end{array}$ & $\begin{array}{c}\text { Total carbon } \\
\text { removed (Mt) }\end{array}$ \\
\hline 2026 & 1 & 0.09 & 0.09 \\
\hline 2032 & 2 & 0.18 & 0.27 \\
\hline 2038 & 4 & 0.36 & 0.63 \\
\hline 2044 & 8 & 0.72 & 1.35 \\
\hline 2050 & 16 & 1.44 & 2.79 \\
\hline 2056 & 32 & 2.88 & 5.67 \\
\hline 2062 & 64 & 5.76 & 11.43 \\
\hline 2068 & 128 & 11.52 & 22.95 \\
\hline
\end{tabular}

But permanently removing carbon from the atmosphere is not the only benefit received from this mussel cultivation exercise. Because of the food value of the mussel, an investment of $€ 1$ billion would attract an annual return, in terms of mussel meat value, of $17 \%$. So, run the facility for 6 years and by the end of that time you will have removed 90,000 $t$ carbon from the atmosphere and sold enough mussel flesh to build a second facility. Six years after that your record will be a total (permanent) removal from the atmosphere of 270,000 $t$ carbon and enough cash in hand to build two more facilities. And so on; towards the end of this century (Table 3).

Who would not want to invest in a programme like that, which, in 50 year's time, was removing so much carbon from the atmosphere annually that we'd have to stop it? Aren't pipe-dreams (and the exponential growth equation) wonderful?

\section{Additional benefits}

We want shellfish producers to greatly expand their production specifically to generate more shell to sequester atmospheric carbon. But, in addition, shellfish shells are a valuable, sustainable, biomaterial with many potential uses ranging from calcium supplementation in poultry farming to $\mathrm{pH}$ regulation in hobbyist aquarium systems (Morris, 2019; Morris et al., 2019). The EU report (Morris, 2019) is written from the conventional point of view that shellfish shells are a waste product that is a candidate for valorisation rather than disposal as a sustainability goal: "... It is clear that shells are a potentially valuable commodity, and do not 
require high-energy processing to give them value. Where shells are produced in a significant volume, it should be possible to find an appropriate valorisation strategy for them within a closeenough proximity to make it both sustainably and economically viable." Nevertheless, although the report seems not to recognise shells as being solidified atmospheric $\mathrm{CO}_{2}$, the statement is made that "... in many cases, shells can provide more inherent value being returned to the marine environment rather than being used in land-based applications..." (Morris et al., 2019). They can indeed, and the reason is simply that most cultivated bivalves are capable of building reefs of sufficient size that they provide coastal protection through their wave-calming effects (Ysebaert et al., 2019).

If we can change the paradigm to cultivate shellfish for their shells, the need to harvest the animals for food is removed. We lose the revenue, of course, but farms placed in remote waters or waters hazardous to shipping, or in contaminated or toxic waters can be left to their own devices. Provide the habitat and the animals will occupy it and thrive as they have for millions of years. When they die, they will leave their shells behind, as a climate-calming legacy, and be replaced by the next generation. Job done. You do not need to kill them in your kitchen, leave that to nature.

On the other hand, if we do amplify farming and harvesting greatly, we will start to produce shellfish meat in excess of that required for the 'shellfish-as-a-delicacy' market. Then we could start thinking about processed shellfish meat as an alternative to terrestrial-reared red-meat products (burgers, steaks, sausages, etc), in the expectation that reduced husbandry of farm animals for meat-eaters will release pastures for afforestation and reduce further destruction of existing natural forests. We suspect that pseudo-beef-burgers made from shellfish meat would be more readily acceptable than those made from the insects that some food technologists are keen to promote. Mussel-prawn-oyster burger, anyone?

Another positive characteristic of shellfish is that they present no conflict between using land to grow food crops and using land to grow trees. Or, for that matter, between growing trees for biofuel and growing native trees to repair and re-establish natural forest ecosystems. Biofuel alleviates fossil fuel usage but does release the $\mathrm{CO}_{2}$ back to the atmosphere when the fuel is burned. There isn't enough agricultural land on the planet to accomplish all these things.

The situation with regard to agricultural land is summed up in this quotation from Moore et al. (2020): 'Only about $7.5 \%$ of the Earth's surface provides the agricultural soil on which we depend for the world's food supply, and this fragment competes, sometimes unsuccessfully, with all other needs: housing, cities, schools, hospitals, shopping centres, landfills, etc. Indeed, there may not be enough soil in the first place. A subsistence diet requires about $180 \mathrm{~kg}$ of grain per person per year, and this can be produced on 0.045 hectares of land. In contrast, an affluent high-meat diet requires at least four times more grain (and four times more land, 0.18 hectares) because the animals are fed on grain and conversion of grain to meat is very inefficient. The Earth has about 0.25 hectares of farmland per person, but only about 0.12 hectares per person of farmland is suitable for producing grain crops. As it stands, the Earth does not have enough land for all inhabitants to enjoy an affluent diet as that is presently defined...' (Moore et al., 2020).

In contrast, farming shellfish uses the shoreline and continental shelf and there is enormous scope for the shellfish sector to grow in those regions, let alone in the open sea. The Views of the World website states the total length of coastlines in the world to be between 1.16 million kilometres and 1.63 million kilometres [http://www.viewsoftheworld.net/?p=5340]. Continental 
shelves cover an area of about 32 million $\mathrm{km}^{2}$, which, according to the Blue Habitats website [https://www.bluehabitats.org/] is only about $9 \%$ of the surface area of the world's oceans.

If we are willing to contemplate planting 1 billion hectares of new forest knowing both that (i) trees cannot solve the excess $\mathrm{CO}_{2}$ problem and (ii) that we do not have enough land to grow food, then surely, we should be willing to contemplate developing towards a situation in which 1 billion hectares $\left(=10,000 \mathrm{~km}^{2}\right.$, which is only $0.03 \%$ of global continental shelf) of coastal waters are devoted to production of animals that will permanently remove $\mathrm{CO}_{2}$ from our tortured atmosphere. There is no need for irrigation, food or fertiliser. Farming shellfish for food can be combined with restoration and conservation of overfished fisheries and usually involves so little intervention (beyond provision of habitats and, where necessary, protection of larvae and juveniles from predation in 'nurseries') that there is no inevitable conflict with other activities. About 70 percent of the Earth's surface is covered by water, we might as well use it to rescue the atmosphere.

With so many positives, it is remarkable to us that there is so much debate about planting trees and no debate at all about cultivating shellfish for carbon sequestering (Moore, 2020). Two paragraphs in a letter received in 2020 from the Scottish Government's Directorate For Marine Scotland (Marine Planning and Policy) give some rationale for the current situation:

'... You rightly say that achieving net zero will require the use of natural carbon sinks for emissions and we must consider all options available, not just forestry, which is why we are also investing in peatland restoration.'

'The national greenhouse gas emissions for Scotland reported through annual Official Statistics are calculated using the UK Greenhouse Gas Emissions Inventory, which is compiled in line with international (IPCC and UNFCCC) scientific guidelines. The inventory currently includes peatland and forestry, but not blue carbon habitats such as oyster reefs, seagrass beds and saltmarsh. This does not mean that these habitats are not important in tackling climate change, indeed they could play a vital role in adaptation by slowing wave action, reducing coastal erosion and lowering flood risk. These habitats also fulfil many important ecosystem functions, such as supporting biodiversity and improving water quality.' (Personal communication 30 January 2020, MPP Reference: 202000011306).

If the International Agencies put more value and devote more intellectual attention to terrestrial remediation processes using green plants (methods that research shows make no net contribution to carbon sequestering), does that mean there is something very wrong with the aquaculture solution? Are we missing something? Well, no, we do not think so because we are not alone in believing that blue carbon habitats hold considerable promise (Macreadie et al., 2019).

Indeed, those who deny the potential of calcifying organisms to sequester carbon for the reason that the $\mathrm{CaCO}_{3}$ they produce represents only a small fraction of the $\mathrm{CO}_{2}$ they cycle during their lives are creating a similar myth to the climate change deniers and global warming sceptics discussed by Moore et al. (2021). The myths that deny the facts that human activities are causing climate change are missing the point that burning fossil fuels emits long-fossilised $\mathrm{CO}_{2}$ additively into today's atmosphere. The myth that shellfish shells represent only a small (even negligible) fraction of the $\mathrm{CO}_{2}$ the organisms respire are also missing the point. And The Point is:

- When a tree dies its entire body, root and branch, is digested and respired and all its carbon is eventually released back into the atmosphere as $\mathrm{CO}_{2}$. Over the forest's lifetime 
there is no net carbon sequestration; indeed, during the forest's lifetime the trees are likely to release previously stored soil carbon.

- When any terrestrial ecosystem (moorland, peat bog, grassland, scrubland) dies, even when a kelp forest ecosystem dies, it is digested and respired and all its carbon is eventually released back into the atmosphere as $\mathrm{CO}_{2}$. The International Agencies expect photosynthetic plants to sequester atmospheric carbon into the lignocellulose of their cell walls. And that they will do, while they are alive. But when a plant dies all of the lignocellulose will be digested (mostly by fungi) and all of its carbon will be returned to the atmosphere as respiratory $\mathrm{CO}_{2}$. A forest that cultivates 10,000 tonnes of timber a year will have all of its carbon returned to the atmosphere within a few decades.

- When shellfish die half the mass of the animal is left behind as permanently stable crystalline $\mathrm{CaCO}_{3}$. Shellfish farms that cultivate 10,000 tonnes of mussels a year, remove 1,606 metric tonnes of $\mathrm{CO}_{2}$ PERMANENTLY from the atmosphere every year.

What's wrong with that? What the International Agencies see wrong with that is revealed in another quotation from that letter from the Scottish Government's Directorate For Marine Scotland:

'There is evidence that the bivalve shells do trap $\mathrm{CO}_{2}$, but the scientific opinion seems to be that the process of doing so releases $\mathrm{CO}_{2}$ from the water back into the atmosphere. There is therefore a net sequestering gain, but smaller than it may initially appear. The current evidence suggests the carbon value in oyster reefs is in the sediment they trap in the reef structure, so bivalve aquaculture would not necessarily result in significant climate mitigation.' (Personal communication 30 January 2020, MPP Reference: 202000011306).

Over the past decade or so several major studies have published careful measurements of the $\mathrm{CO}_{2}$ fluxes associated with shell formation, they tend to come to the not very surprising conclusion that more $\mathrm{CO}_{2}$ is released to the atmosphere by the animal's respiration than is sequestered in the shell. This usually gives rise to the conclusion that shell formation in cultivated bivalves cannot be part of a carbon sequestering system, and this has been said so often over the years that the claim has reached the status of a self-evident truth. But it is not true.

One specific example will suffice but before we go any further we want to make it clear that we make no criticism of the science or its analysis done for this study (or other related studies); we criticise only the final conclusion. Munari et al. (2013) studied shell formation in the cultivated bivalve Mytilus galloprovincialis (the farmed Mediterranean mussel) in the River Po Delta, Italy. They measured respiration and calcium carbonate. The ratio of $\mathrm{CO}_{2}$ released to $\mathrm{CaCO}_{3}$ crystallised into the shell was calculated. They estimated that $M$. galloprovincialis sequestered $136.6 \mathrm{~mol} \mathrm{CO}_{2} \mathrm{~m}^{-2}$ year $^{-1}$ (= $6 \mathbf{~ k g ~ C O}_{2} \mathbf{~ m}^{-2}$ year-1) for shell formation, but the $\mathrm{CO}_{2}$ fluxes (by which they mean release to the environment) due to respiration and calcification were 187.8 and $86.8 \mathrm{~mol} \mathrm{CO}_{2} \mathrm{~m}^{-2}$ year-1 (equivalent to $8.26 \mathrm{~kg} \mathrm{CO}_{2} \mathbf{~ m}^{-2}$ year-1 and $3.82 \mathbf{~ k g ~ C O}_{2} \mathbf{~ m}^{-2}$ year $^{-1}$ ) respectively. From which the authors suggest that mussel farming adds $\mathrm{CO}_{2}$ to seawater, which leads them to conclude (in line with many other authors, before and since) that shell formation in cultivated shellfish cannot be part of carbon trading systems (and this final phrase is in the title of their paper).

But that is a conclusion too far because the $6 \mathrm{~kg} \mathrm{CO}_{2} \mathrm{~m}^{-2}$ year-1 formed into the animals' shells is permanently insoluble. The correct conclusion from this study is that farmed Mediterranean mussels require a flux of $12.08(=8.26+3.82) \mathrm{kg} \mathrm{CO}_{2} \mathrm{~m}^{-2}$ year-1 in order to crystallise $6 \mathrm{~kg} \mathrm{CO}_{2}$ $\mathrm{m}^{-2}$ year ${ }^{-1}$ into permanently sequestered $\mathrm{CaCO}_{3}$. In other words, each year half the $\mathrm{CO}_{2}$ which 


\section{is churned between animals, seawater and atmosphere is REMOVED from the atmosphere.}

The emerged River Po delta area is estimated at about $700 \mathrm{~km}^{2}$ (Ninfo et al., 2018). Shellfish cultivation, mainly of mussel, clam and oyster, is well-established, and this area is one of the most important such sites in Europe, involving about 1700 operators and 83 companies (Tamburini, et al., 2020). Production of mussels by these farms is estimated to be 10,000 tonnes per year (Tamburini et al. 2020). The quantitative measurement of the respiratory flux of $\mathrm{CO}_{2}$ needed to produce the shell is made irrelevant by the facts that (a) permanently crystallised $\mathrm{CaCO}_{3}$ in shellfish shell amounts to $30 \%$ to $50 \%$ of the shellfish farmers' harvest and (b) on a molar mass basis, $\mathrm{CO}_{2}$ represents $44 \%$ of the mass of calcium carbonate. So, it's an easy calculation that 10,000 tonnes mussels $=3,650$ tonnes of shell $=1,606$ tonnes $\mathrm{CO}_{2}$ removed from the atmosphere annually. Surely, that amount of carbon sequestered by the farmed Mediterranean mussels of the River Po Delta would be a useful part of carbon trading systems?

Increase that by a million-fold, and we would be removing 1.6 billion tonnes of $\mathrm{CO}_{2}$ from the atmosphere every year, just by farming mussels. It is important to appreciate that this scale of operation is not expecting too much; The Global Agriculture website [https://www.globalagriculture.org/] estimates there are 570 million terrestrial farms in the world - and we are blest with far more ocean than farmland!

Globally, we consume around 350 million tonnes of meat a year. Meat has a much higher energy footprint than any other food. It takes 75 times more energy to produce meat than corn. And it takes an area of cropland 7 times the size of the EU to produce food for the livestock animals of Europe (most of the additional cropland required to meet this demand is in China, the US, and Indonesia) [https://www.theworldcounts.com/]. If we put that amount of effort into producing 350 million tons of shellfish meat (rather than livestock meat) then the shells of that shellfish harvest would be removing 42 million tonnes of carbon from the atmosphere each year.

We describe the quantitative measurement of the respiratory flux of $\mathrm{CO}_{2}$ needed to produce the shellfish shell as irrelevant because ALL aerobic organisms release respiratory $\mathrm{CO}_{2}$ to the atmosphere through their metabolic activities. And that includes forests (and other green plants, aquatic and terrestrial), though green plants have the advantage of photosynthesis. It is photosynthesis which enables green plants to fix more $\mathrm{CO}_{2}$, initially into carbohydrates, than they release through respiration, in the daylight. When the lights go out, though, all the plants in the forest breathe out $\mathbf{C O}_{2}$. That's LIFE. The clincher is at the end of the organism's life cycle.

Atmospheric $\mathrm{CO}_{2}$ sequestered by shellfish is undigestible, crystalline and chemically stable calcium and calcium-magnesium carbonates; when the animal dies the shell remains for geological periods of time. Effectively, the $\mathrm{CO}_{2}$ is permanently removed from the atmosphere. That's the animal's generous legacy and our inheritance.

Shellfish cultivation is the only industry in which a massive increase in productivity will benefit the atmosphere. We are not convinced that forestry can do what is needed, and the heavyindustry approach is alarmingly expensive. Here we quote from the Wikipedia article on Carbon Capture and Storage [source: https://en.wikipedia.org/wiki/Carbon capture and storage]:

'The increased energy required for the carbon capturing process is also called an energy penalty. It has been estimated that about $60 \%$ of the energy penalty originates from the 
capture process itself, $30 \%$ comes from compression of $\mathrm{CO} 2$, while the remaining $10 \%$ comes from electricity requirements for necessary pumps and fans. CCS technology is expected to use between $10 \%$ and $40 \%$ of the energy produced by a power station. CCS would increase the fuel requirement of a plant with CCS by about $15 \%$ for a gas-fired plant. The cost of this extra fuel, as well as storage and other system costs, are estimated to increase the costs of energy from a power plant with CCS by $30 \%-60 \%$, depending on the specific circumstances.'

Compare with this the humble shellfish; cultivate the shellfish in order to sell a tasty food and get the CSS for free! And do it in the ocean, leaving you free to save the forests in the way that the forests need to be saved.

Another criticism levelled against our argument we should use shellfish for sequestering $\mathrm{CO}_{2}$ is that there may be a major problem with large scale intensive bivalve culture because of profoundly damaging effects on the overall marine ecosystems. This is said to be because bivalves of most species filter out huge quantities of both plant and animal plankton (including many larval stages), and when grown intensively they can create single species monocultures. The worst expression of this is when monocultures cause reduced growth rates, increased bivalve diseases and an environment dominated by a single bivalve species (Earll, 2018).

We do not accept this as a criticism because while there are, indeed, considerable dangers in monocultures, we do not believe for one moment that there is any danger of damaging the overall marine ecosystem, because the conservation of that ecosystem would be part of the design planning for any shellfish cultivation exercise. We speak most often about mussel farming because we are most immediately aware of that species. But there are hundreds, perhaps thousands, of shellfish candidates for cultivation, molluscan and crustacean (Utting \& Spencer, 1991; Helm et al., 2004) (see Section 7, below). Consequently, a range of cultivated ecosystems can be designed to suit different habitats and locations (integrated multi-trophic aquaculture), avoiding monocultures by combining filter feeders with detritus feeders, and phytoplankton farming with zooplankton cultivation (Heilweck \& Moore, 2021).

Furthermore, there are many shellfish fisheries around the world that have been over-fished or even fished out, so a useful start could be made simply as a conservation measure to repair the ecosystem damage that's already been done. And, of course, $70 \%$ of the planet is covered in ocean; how many intensive bivalve farms would you need to damage that?

Instead of thinking about filling the ocean with mussel farms, think about seeding the oceans with appropriately designed communities of organisms, molluscs and crustaceans alike (for which see Heilweck \& Moore, 2021) that will support the basic need: which is to cultivate shellfish for their shells, and take whatever else they offer, whether that be food (human and/or animal), reef-building, pollution-filtration, coral reef reconstruction (Section 14, below), as a free by-product.

There is no shortage of scientific and practical knowhow about what could be done to rescue our distressed marine life, but there is a divide between what is possible and what we are doing due to poor financial, legislative and political support. Bindoff et al. (2019) state that "... blue carbon can contribute to mitigation for many nations, but its global scope is modest ...". Blue carbon science is relatively young but has so well revealed the importance of aquatic ecosystems in the carbon balance and ecosystem services of the whole planet that it deserves significantly increased attention (Macreadie et al., 2019). The potential benefits are being made 
clear but to reap those benefits requires huge effort, central governance, huge scale, and huge finance.

Gordon et al.(2020) state categorically “... Marine restoration projects are undervalued ...”. In their final paragraph they conclude that "... Political agreements for global reductions in atmospheric carbon have been slow to emerge. Relying on their implementation as the only solution to the degradation of tropical habitats is a major gamble. In the meantime, restoration projects could help maintain species survival and ecosystem services, ultimately providing humanity with the breathing space to stabilize the climate ...".

Duarte et al. (2020) conclude that “... Rebuilding marine life represents a doable Grand Challenge for humanity, an ethical obligation and a smart economic objective to achieve a sustainable future ....". The political limitations of conventional ecosystem governance are discussed by Morrison et al. (2020), who conclude that securing a future for marine ecosystems (in their case, coral reefs) "... under climate change is a political challenge as much as an ecological or social one ...". In terms of creating sustainable ecosystems globally the immense promise of blue carbon science so strikingly evident that it must be taken more seriously. But more than anything else it requires the recognition that cultivation of coccolithophores, corals, crustacea and molluscs on a massive scale would have the effect of removing a massive amount of $\mathrm{CO}_{2}$ directly from the atmosphere; here, now and permanently, making a continued contribution to the health of the whole planetary ecosystem (Fig. 3). It would be a criminal dereliction of duty if humanity failed to grasp this last opportunity to carry out this 'doable Grand Challenge'. And the sentence for such a criminal act is extinction.

\section{The shellfish cultivation industry offers unique opportunities for limiting climate change and enhancing conservation strategies}

A few more statistics derived from the present-day situation give an idea of the scale of the shellfish cultivation programme required in the future to make effective drawdown of $\mathrm{CO}_{2}$ from the atmosphere and dramatically reduce climate change. In Section 1, above, we estimate that 4.84 million tonnes of $\mathrm{CO}_{2}$ per year is being captured, and mineralised, from the atmosphere by current aquaculture activities around the world. In carbon-offset terms, that's equivalent to one million business class return flights between London Heathrow and JFK New York (6 billion miles of flying per year, every year). Returning to mussels, we also estimate above (Section 5) that shellfish farms designed to produce 10,000 tonnes of mussels per year, such as the Po River delta farms (Tamburini et al. 2020), would permanently remove from the atmosphere an annual total of 1,606 metric tonnes of $\mathrm{CO}_{2}$.

According to the Carbon Offsetting website one business class return flight LHR (London Heathrow) to JFK (New York) = 2.17 tonnes of $\mathrm{CO}_{2}$ and would cost between US $\$ 8$ and US $\$ 17$ per tonne to offset, depending on the offsetting programme you wish to support (planting trees, renewable energy, community projects, etc) [https://www.carbonfootprint.com/].

The same website calculates that the carbon footprint of DM's Ford Focus (EU 2015 FORD All New Focus, Model Year Post 2015 1/2 1.6 Duratorq TDCi (115PS) With Stop/Start - 5 Door) is 0.22 tonnes $\mathrm{CO}_{2}$ per 1,000 miles (costing between US $\$ 3$ and US $\$ 7$ to offset, depending on the programme). So, the shells of 10,000 tonnes of mussels:

- $\quad$ offset 740 return business class tickets (equivalent to about US\$19,000 in offsetting fees); OR

- $\quad$ offset DM driving 7,300,000 miles (equivalent to about US\$33,500 in offsetting fees). 


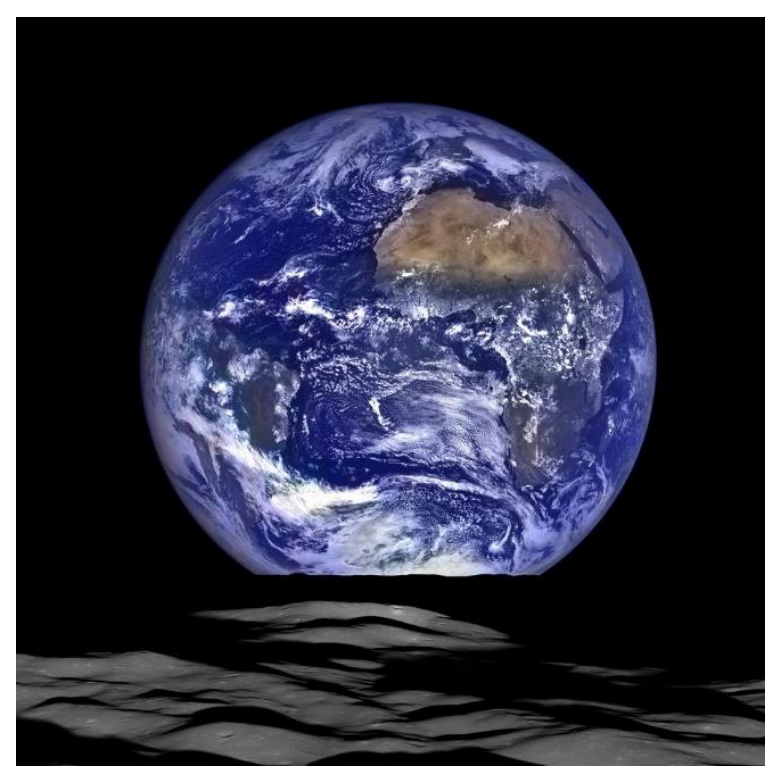

Fig. 3. The Earthrise over the Moon, as seen from above Compton crater from the orbital vantage point of NASA's Lunar Reconnaissance Orbiter spacecraft. The large tan area in the upper right of the Earth's disc is the Sahara desert, and just beyond is Saudi Arabia. The Atlantic and Pacific coasts of South America are visible to the left [source: NASA/GSFC/Arizona State University].

We suggested above that a million bivalve shellfish farms like this might remove 1.606 billion $\left(1.6 \times 1^{9}\right)$ tonnes $\mathrm{CO}_{2}$ permanently from the atmosphere each year. Global carbon emissions in 2014 from fossil fuel use were 35.9 billion tonnes of carbon dioxide [https://www.co2.earth/global-co2-emissions]. So, a million mussel farms would permanently remove about $4.5 \%$ of the global $\mathrm{CO}_{2}$ emissions in each year. The call for a million mussel farms is by no means an extreme or unrealistic proposition. Imagine a mussel farm on every offshore wind turbine, every oil and gas rig, every pier, wharf and jetty, every breakwater or harbour wall; imagine cultivating cockles (and other clams) in every shallow sandy/muddy bay (see Section 8, below). Imagine restocking and extending every fished-out oyster fishery, every fished-out scallop fishery. We could start tomorrow.

We believe that a high priority should be given to having 'cultivation of blue carbon sequestration' included as projects on carbon offset websites. There is a wide range of potential projects, ranging from support for developing/expanding local subsistence fisheries as a means to employ and feed communities in need, right through to the industrial scale of seamount installations (Heilweck \& Moore, 2021) and ocean-going factory ships (Heilweck \& Moore, 2021; Moore, 2021) that might be supported by high-energy industries needing to compensate their heavy carbon footprints, and which have all the necessary skills and experience to take such large-scale efforts forward.

In 2011, the Guardian website published an article entitled $A$ complete guide to carbon offsetting in which Duncan Clark summarised the offsetting debate in an edited extract from his book The Rough Guide to Green Living (Clark, 2009) [URL: https://www.theguardian.com/]. Sadly, the blue carbon industries do not feature in the debate. 
It's worth repeating that the shellfish industry is the only industry on the planet that could save the atmosphere by a massive increase in its production. So, why is carbon sequestration not being promoted more widely by the shellfish sector? We've asked that from the beginning and can't understand why the guys who haul shellfish by the tonne into their boats in cold, driving rain haven't realised that half of what they are hauling aboard is solidified $\mathrm{CO}_{2}$ from the atmosphere. And then used that fact to help sell the product.

For the producers, restaurateurs and end users it is probably mind-set tinged with a lack of basic biological knowledge. The mind-set is dominantly that shellfish is a food, and the shell is a waste that has to be disposed of. End of thinking: who's doing the washing-up?

For the man in the street this is understandable and excusable. You don't express concern that the cattle spent their lives farting methane into the atmosphere when you're tucking into your rib-eye steaks, so why be grateful that your 'moules marinière for two' has just taken about $20 \mathrm{~g}$ of $\mathrm{CO}_{2}$ out of the atmosphere, and so will the next plate, and the next? What is unfortunate is that this unthinking attitude applies to the professionals as well.

For example, a research paper in the Journal of Applied Poultry Research in 2013 starts with this: 'DESCRIPTION OF PROBLEM. One of the major industries in Atlantic Canada is harvesting and processing of shellfish. This activity generates approximately 140,000 t of raw material annually and accounts for almost $20,000 \mathrm{t}$ of waste, with the majority coming from Atlantic snow crab, American lobster, and seashells such as whelk, abalone, blue mussel shell, surf-clam shell, soft-clam shell, scallop shell, quahog shell, and abalone shell ... The slow biodegradability of these waste products has raised concerns over disposal practices and their impact on the environment...' (quotation from Safamehr et al., 2013). The paper goes on to consider shellfish shells as useful calcium sources for supplementing poultry feeds, which is a perfectly respectable use for them.

Another review of shell waste (Jović et al., 2019) points out that the aquaculture industry is a globally attractive source of cheap and healthy food for our growing population because of its need for relatively small investment and its low energy consumption, but as shellfish shells can account for up to $75 \%$ of total bivalve body weight, they claim that contamination of the ecosystem by waste shells can be a significant environmental problem if it accumulates at coastal sites. This publication aims to review recent trends in shell waste applications in the light of the European Union's Circular Economy Action Plan [https://eur-lex.europa.eu/] that stresses development of new technologies to exploit waste as a resource and contribute to sustainable development (Jović et al., 2019). But why do these publications and reports raise such concerns over shells as a waste disposal problem which will have a negative impact on the environment, when the ecological truth is quite the reverse?

Bivalve molluscs are described as ecosystem engineers creating biogenic reef habitats of such significant size that they engineer entire ecosystems and can be used as a natural component of coastal protection schemes (Mann et al., 2009; Ysebaert et al., 2019). It is the accumulated shells of past generations of shellfish that is the foundation of the reef ecosystem "... If you have an oyster shell, the best thing to do is to put it back on the reef in order to start an ecological system. Once you've got the reef, then other fish come along, and other flora and fauna can form around them. They purify the water and filter it, making it useful. But not everybody knows this ..." (Smith, 2015). And that is why, if you have a pile of shellfish 'foodwaste', you should put it back where the animals came from. 
Murphy et al. (2020) suggest treating mussel shells "from aquaculture waste streams" with dilute acetic acid to make an absorbent sponge-like material, composed of recombined calcite crystals, that can absorb dyes and crude oil from polluted water. Waste shells from aquaculture have been used as a low cost $\mathrm{CaCO}_{3}$ source to produce calcium oxide $(\mathrm{CaO})$, which is widely used as a catalyst and chemical feedstock in industry. Heating $\mathrm{CaCO}_{3}$ to over $800{ }^{\circ} \mathrm{C}$ (calcination) results in the conversion of solid $\mathrm{CaCO}_{3}$ to solid $\mathrm{CaO}$, liberating gaseous $\mathrm{CO}_{2}$ in the process. Calcined oyster shells have been shown to be an effective catalyst in the conversion of soybean oil into biodiesel (Nakatani et al., 2009); calcined cockle shells to convert palm olein to biodiesel (Boey et al., 2011); and calcined freshwater mussel shells for conversion of Chinese tallow oil to biodiesel (Hu et al., 2011). Also, calcined oyster shell-derived calcium oxide was used to modify copper-based catalysts for synthesis of methanol (Wisaijorn et al., 2017). All these studies demonstrate that calcined mollusc shells from the aquaculture industry can very effectively replace the more commonly used mined $\mathrm{CaCO}_{3}$, such as limestone; thus, replacing a calcination process that adds even more fossilised $\mathrm{CO}_{2}$ to the atmosphere, with one that merely cycles present day $\mathrm{CO}_{2}$ from atmosphere-to shell-to atmosphere, without making a net contribution to present day atmospheric carbon.

Although bivalve shells are almost entirely composed of $\mathrm{CaCO}_{3}$, with only a minor component of their structure being a protein component, the $\mathrm{CaCO}_{3}$ crystals in the shells of crustacea are built into a significant scaffold of the polysaccharide chitin. Shell wastes from shrimp, crab, lobster, and krill contain large amounts of chitin, that can be extracted by deproteinising and demineralising the exoskeletons. The chitin biopolymer, and its derivatives chitosan and related products, exhibit many biomedical activities, including as antioxidant and immunomodulator (with potential for cancer treatments) and, aside from medical uses, can be exploited in various other applications, such as cosmetics, food processing, and textiles (Hamed et al., 2016), and even a film that is a biodegradable alternative for single-use plastics (Srinivasa \& Tharanathan, 2007; Shamshina et al., 2019; and view https://www.theshellworks.com/).

The book Goods and Services of Marine Bivalves (Smaal et al., 2019) deals with a wide range of aquaculture topics including genomics-driven biotechnological innovations like new pharmaceuticals from molluscs, habitat and ecosystem-engineering modification in coastal protection by reef-building bivalves, water clarification services provided by their filter feeding and even shells as collector's items, but does not include a chapter dealing specifically with the potential service of extracting carbon from the atmosphere. Chapter 12 (Filgueira et al., 2019) in this book comes closest to a revelation in which these authors state clearly "... In valuing the ecosystem service of mussel farming in the carbon cycle a distinction has been made between the shell (waste) and the tissue (food). Following this rationale, the goods and services of mussel farming in deep fjords includes the valorization of the shells as a net sink of $\mathrm{CO}_{2} \ldots$... (pp. 245-246). Sadly, despite this promising start they apply this consideration only to harvested mussels, not to those that die in situ, and their final conclusion is that:

“... Under these considerations, bivalve shells can be considered net sinks of $\mathrm{CO}_{2}$ and consequently provide additional ecosystem services besides the food provided by the tissue. A full life cycle analysis should be performed to account for the emissions required to properly dispose of the shells. The $0.45 \mathrm{~g}$ by the shell of each cultured mussel in Norway is hardly significant taking into account that a regular car produces more than 100 $\mathrm{g} \mathrm{CO}_{2}$ per km ..." (Filgueira et al., 2019; p. 246).

Now, we do not believe you can get much of a meal from ONE mussel. Rather, we think that a reasonable serving of moules marinière requires at least 20 mussels $\left(=10 \mathrm{~g} \mathrm{CO}_{2}\right.$ sequestered). So, a family of five, treating a similar family of friends to a meal out, could carbon-offset the drive to the restaurant. That consideration aside, the conclusions of Filgueira et al. (2019) miss 
the points that (a) disposal can mean no more than dropping the empty shells back into the fjord; and (b) that despite all its trees, Norway has no other industry that permanently removes carbon from the atmosphere.

The only publication we have found that recognises the true potential for marine calcification to remove $\mathrm{CO}_{2}$ from the atmosphere is a newspaper article written by Steve Connor, which was published in The Independent with the promising title 'Can seashells save the world?' (Connor, 2008). Although this article gives most prominence to coccolithophores (see Moore, 2021), which "... are microscopic marine plants that convert carbon dioxide into chalk ... fighting global warming ..." the article goes on to say:

“... Scientists have already estimated that some 118 billion tons of carbon released into the air as carbon dioxide between 1800 and 1994 have been taken up by the oceans worldwide. Indeed, about a third of the carbon dioxide produced by human activities since the start of the Industrial Revolution has been absorbed by the seas. So, without the capacity of the ocean to act as a natural carbon sink, the concentration of carbon dioxide in the air today - about 380 parts per million - would be significantly, and dangerously, higher." (Connor, 2008).

But, most importantly, this article recognises the central truth that professional marine scientists seem to be obscuring with irrelevant detail and caveats:

"... Marine calcification actually produces carbon dioxide in the short term, but in the long term it takes carbon out of the atmosphere, for example by the formation of limestone rock deposits on the seabed. Indeed, marine calcification is estimated to be the biggest carbon sink on earth over geological timescales by forming layers of calcium carbonate, the basic ingredient of chalk, limestone and marble." (Connor, 2008).

Of course, we would respond to Steve Connor's question 'Can seashells save the world?' with a resounding 'Yes they CAN.'

\section{Our primeval shellfish-eating tradition}

The human tradition of eating shellfish goes back a long way; it might even rate as being a primeval behaviour. A variety of evidence indicates that Homo sapiens arose in Africa between 200,000 and 100,000 years ago. When their find of the remaims of a 164,000-year-old meal of shellfish in a cave on the South African coast was reported, the editorial summary of the published paper stated that "... the first thing Homo sapiens did once he and she had evolved was head for the beach ..." (Marean et al., 2007).

This was likely to have been more a matter of survival than a holiday trip because over this stretch of time in our history the world was in a changing but predominantly inhospitable glacial stage, causing cold and dry conditions that forced early hominids to the coastline. It is thought that there was a gradual accumulation of a package of modern human behaviours in Africa, that included the use of bone tools, the making and use of flint tools, increasing geographic range (exploration), specialised hunting, gathering of aquatic resources, and eventually long distance trade and use of pigments for decorative arts. The generally accepted idea is that this 'package of behaviors' originated in Africa and were later exported to other regions of the world by migrations along the coastlines (Petit et al., 1999; McBrearty \& Brooks, 2000; Phillipson, 2005; Marean \& Assefa, 2005).

The earliest fossils of Homo sapiens are located in Africa and dated to the late Middle Pleistocene (now called the Chibanian and estimated to span the time between 126- \& 770- 
thousand years ago). Perhaps on several occasions between 60 and 200,000 years ago, modern humans dispersed, probably mainly along the coastlines initially, into Europe, Asia and more distant locations of Japan, the Philippines, Australia, and eventually the Americas.

This is the familiar 'Out of Africa' theory; that Homo sapiens developed first in Africa and then spread around the world supplanting all other hominid species present in Asia before the appearance of modern humans. A recent evaluation of issues raised by this theory, particularly single versus multiple waves of dispersal, and interactions with indigenous populations of other hominid species (interbreeding and/or replacement) concluded that there is growing evidence for multiple dispersals prior to 60,000 years ago in regions such as southern and eastern Asia, and that "... Modern humans moving into Asia met Neanderthals, Denisovans, mid-Pleistocene Homo, and possibly $\mathrm{H}$. floresiensis, with some degree of interbreeding occurring. These early human dispersals, which left at least some genetic traces in modern populations, indicate that later replacements were not wholesale ..." (Bae et al., 2017).

Remains of the oldest known seafood dinner were those discovered by Marean et al. (2007) when excavating a sea cave near Pinnacle Point on the southern coast of South Africa (roughly midway between Cape Town and Port Elizabeth). Dated to 164,000 years ago, the find comprised about two dozen shells, mainly Brown Mussels (Perna perna) but also including at least one Whale Barnacle (a crustacean, subfamily Coronulinae), which indicates a diversity of taste for seafood. The next oldest known seafood dinner dates to 125,000 years ago, during the last interglacial, and was found on the Red Sea coast of Eritrea (Walter et al. 2000). Then, about 110,000 years ago, Neanderthals were cooking shellfish in caves on the coast of Italy (Erlandson, 2001). This author maintains that "... aquatic and maritime adaptations (including seafaring) played a significantly greater role in the demographic and geographic expansion of anatomically modern humans after about 150,000 years ago. Another significant expansion occurred somewhat later in time, with the development of more sophisticated seafaring, fishing, and marine hunting technologies ..." (Erlandson, 2001).

In fact, Erlandson (2001) gives a useful outline of what 'shellfish' means in an archaeological context: "... The generic term shellfish is usually used to refer to a variety of aquatic invertebrates, dominated by molluscs (bivalves and univalves [for example, limpets]), but also including crabs, sea urchins, barnacles, shrimp, and other relatively common organisms ... [which are usually] relatively small ... What they lack in size, however, many shellfish make up for in quantity and accessibility - many types are found in large and sessile aggregations. While most shellfish provide nutritious sources of complete animal proteins and some vitamins or minerals, most are relatively low in fat, carbohydrates, and calories ..." (Erlandson, 2001).

A few years earlier, Jones \& Richman (1995) had studied the prehistoric resource value of the California mussel (Mytilus californianus). This is one of the most abundant bivalves found in the archaeological record of the west coast of North America and is still the most common among present day intertidal populations. They found the mussels to be "... high in protein, low in carbohydrates, and could contribute to complete diets among highly mobile foragers ..." Significantly, they state that "... Mussels could not be overexploited to extinction, but resource value declines with frequent exploitation, rendering them of less dietary significance in intensified economies ..." (Jones \& Richman, 1995).

A more recent study evaluates the usefulness of shellfish for human subsistence and the longterm mobility of human migration patterns, this time a continent and ocean away from the Californian coast, around the Red Sea (Hausmann et al., 2020). These authors studied shell remains found in a cluster of middens which date to approximately 7,000 to 5,000 years ago on 
the Farasan Islands of Saudi Arabia, which is an archipelago of coral reef islands located about $50 \mathrm{~km}$ offshore from the present day city of Jizan. A midden is an old dump of domestic waste associated with past human occupation, and possibly, settlement. In this case the shell remains were from Conomurex fasciatus, known as the lined conch, a species of sea snail common in the Red Sea. The purpose of the study was to determine the long-term sustainability of shellfish harvesting over the 2,000 year period covered by the middens, because the southern Red Sea is considered to be the southern gateway for migrations out of Africa and into Arabia. No indications of resource depletion during this occupation period were found. "... These results have implications for the interpretation of shellfish harvesting during periods of terrestrial aridity and specifically the potential of shellfish as a reliable food source during Palaeolithic migrations out of Africa ..." (Hausmann et al., 2020).

The variety and richness of marine resources that would have been available to the migrating humans is clear from a study of Mesolithic (15,000 to 5,000 years old) middens at an archaeological site at Sand on the Applecross Peninsula in Wester Ross, Scotland. Shellfish were an integral part of local life as part of a rich and varied diet which included other marine species such as crab and fish, as well as terrestrial animals and plants (Milner, 2009).

The limpet (Patella vulgata) was the most abundant shell in these middens; the periwinkle (Littorina littoralis) was fairly common, as was the dog whelk (Nucellus lapillus), and the topshell (Gibbula cineraria) was also represented, but although this species can be consumed the shells are also decorative and may have been under-represented in the middens through being used for bead jewellery. Beads made from shells have been found at other sites up to 120,000 years old (Henshilwood et al., 2004; Vanhaeren et al., 2006).

Bivalves found on the site included mussels (Mytilus edulis), cockles (Cardium edule), scallops (Pecten maximus) although the latter is possibly also under-represented in the middens because the shells are useful as containers and for tools, and razor shells (Ensis sp.) though, in this case too, the empty shell is potentially useful as a spoon-like tool so may not have been discarded. One species absent from the Sand site middens is the oyster (Ostrea edulis). Milner (2009) suggested that oysters may not be available on this shore. But other archaeologists believe that because the early humans lacked tools that would open the shells of live oysters, they were placed over fire or heated stones and cooked until the oyster shells opened up. Oyster shells from the Mesolithic period do show evidence of fire scorching, and there is evidence for the use of fire by early humans back to about four hundred thousand years ago.

Possibly the most celebrated oyster shell middens in the US were located on the upper Damariscotta River in Lincoln County, Maine, that empties into the Atlantic Ocean. It is famous for two enormous oyster shell heaps known as the Whaleback and Glidden middens created between 2,200 and 1,000 years ago by the Native Americans who once populated the area. When first found they were up to 30 feet $(9 \mathrm{~m})$ deep and covered several acres. So large, in fact, that they were mined in the late 1880s to supply a factory that processed the shells into chicken feed (Sanger \& Elson-Sanger, 1986).

Overall, then, it seems safe to say that whenever, wherever, and however often, early humans did come 'Out of Africa' they took the coastal route and carried with them a package of behaviours that included a taste for a wide variety of shellfish. 


\section{Ancient clam gardening}

So far, we have been describing the communities of early humans that migrated out of Africa as though they were exclusively hunter-gatherer peoples, beachcombing along the coastline collecting potential sources of food and other things of interest or use. That's not the whole story, because early humans had enough awareness and knowledge of their environment to undertake various gardening activities to increase yields of various food sources.

The evidence that has so far emerged is that indigenous communities, referred to as First Nations in Canada, along the northwest coast of North America actively managed several resources of shoreline habitats. They pruned, and even fertilised shrubs and trees to increase berry and fruit production and tended 'root gardens' for various plants and edible bulbs. In aquatic ecosystems they made stone fish traps at the mouths of rivers and constructed wooden fish weirs in streams to harvest Pacific salmon and managed their catches and catching methods to limit the impact of their fishing on the resource they were harvesting. Most remarkable of all in the context of our present discussion is that in ancient times indigenous human communities intervened in the management of their coastlines and engineered intertidal rock-walled terraces as clam gardens, ancient mariculture biotechnologies, which have been documented from northwest Washington State, through British Columbia, and onto southeast Alaska (Jackley et al., 2016).

These terraces were made by constructing rock walls in the mid-intertidal zone, close to the lowest low water tide level. Then, through a combination of natural sedimentation as the tides ebbed and flowed and active addition of gravel and discarded shells by the people themselves, naturally sloping clam beaches were transformed into flattened terraces composed of rock and sediment on the landward side of the retaining wall of rocks, often with root gardens at the top of the beach (Fig. 4).

There does not seem to be any evidence for this clam garden technology along the south east Asian coastlines of the Pacific, which might correspond to an 'Out of Africa' migration route around the coast of south east Asia and then North to cross the Bering Strait into North America; "... we do not know of any examples of clam gardens elsewhere in the world - and I have really tried to find them ... The terracing of the intertidal (with clam gardens and root gardens) seems to be unique to this region ..." (Dana Lepofsky, 2020, personal communication).

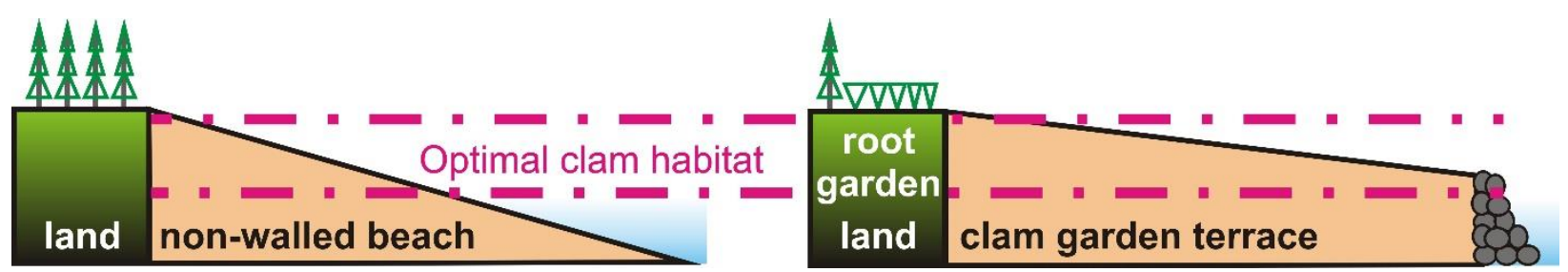

Fig. 4. Sectional schematic illustrating the basic architecture of a clam garden. The structure of the clam garden (at right) is compared with the profile of the original beach (at left). Clam gardens were often accompanied on the landward side by root gardens, which were tended for a variety of plants and edible bulbs and where shrubs and trees were pruned, and even nourished, to increase berry and fruit production. Redrawn and adapted from Groesbeck et al. (2014) and Wyatt (2015). 
Table 4. YouTube videos describing how, for thousands of years, indigenous people all along the Pacific Northwest coast, from northwest Washington State, through British Columbia, and onto southeast Alaska, have cultivated clams in tidal clam gardens

Clam Gardens: Filling in the Gaps. Illustrating the research paper of Smith et al., 2019. https://youtu.be/oJA3Erh810c

Simon Fraser University helicopter survey of clam gardens. Over Tracey Island, near the north end of Vancouver Island. https://youtu.be/eWvkmcsXhtQ

Mysteries of Ancient Clam Gardens. Native Watchman of the Mamalilikulla Qwe'Qwa'Sot'Em territory, Tom Sewid, takes us on a tour of the ancient clam gardens (lo'hewae) of coastal British Columbia https://youtu.be/DIGn4yd15 I

Prof. Anne Salomon describes Ancient Clam Gardens. https://youtu.be/R4b1kVJrEPI

Restoring a Coast Salish Clam Garden. On Gulf Islands National Park Reserve
https://youtu.be/cv247vHBIIA

A Wall Worth Building. Making Clam Habitat Great Again https://youtu.be/22Nytmxw2Z8

Clam Gardens - Learning Together. At Gulf Islands National Park Reserve
https://youtu.be/i2wPVx4sCNO

Quadra Clam Gardens Time-Lapse. A very short video showing an archaeological excavation in the 3hour window in which a clam garden is exposed https://youtu.be/viYc4u3NoDs

It is important to recognise that written details about the ecological function, use, and management of clam gardens is only now being accumulated by the present day scientific community. The antiquity of this technology is truly prehistoric, meaning that there is no written tradition relating to it, but there is an aural tradition which is conserved by present day First Nations peoples, some of which can be found in the YouTube videos listed in Table 4.

This coastal engineering activity, called clam gardens by western science, has played a significant role for many millennia in First Nations communities of the Pacific Northwest; certainly, for up to 11,500 years (Smith et al., 2019; Toniello et al., 2019). However, most of the gardens have not been tended for many decades and are in need of restoration. Restoration efforts are currently focused on improving traditional and scientific knowledge of the gardens that remain through interviews with First Nations, researchers, and representatives of Tribal Park Reserves (Mclntosh, 2016).

Clam gardens were clearly developed by the First Nations communities to enhance the productivity of their favourite shellfish in a location convenient to them. Recent comparative research has demonstrated that clam gardens do, indeed, extend the optimal growing conditions for clams, increasing both densities and biomass of the native littleneck clams (Leukoma staminea) (Jackley et al., 2016). Overall, clam gardens contained 4 times as many butter clams (Saxidomus gigantea) and more than twice as many littleneck clams relative to nonwalled beaches. So, there is clear evidence that clam gardens increased clam biomass and density and were used together with other harvesting and processing behaviours to ensure the longevity of food security (Groesbeck et al., 2014). However, further than this, the local environments included a wide range of species that could also find the clam gardens to be an attractive habitat. 
The dominant bivalves found on the beaches of this central coast of British Columbia include, as well as littleneck clams, butter clams (Saxidomus gigantea), macoma clams (Macoma spp.), horse clams (Tresus spp.), eastern soft shell clams (Mya arenaria), and heart cockles (Clinocardium nuttallii). The coastal regions also include eelgrass habitats, intertidal and subtidal kelp forest habitats, with the result that there is a diversity of reef associated fish including lingcod (Ophiodon elongatus), rock fish (Sebastes spp.), and greenling (Hexagrammidae), and invertebrates, such as northern abalone (Haliotis kamtschatkana), sea urchin (Strongylocentrotus spp.), marine snails (Astrea gibgerosa, Littorina spp., Nucella spp.), mussels (Mytilus spp.), limpets (Acmaea spp., Lottiidae), chitons (Polyplacophora), and barnacles (Semibalanus spp., Balanus spp.); overall, more than enough to tickle the most jaded palate of a migrating traveller.

One more point of potential interest for the future is that quantification of the clam garden habitats constructed in northern Quadra Island, BC, Canada revealed that clam garden walls were built on $35 \%$ of the shoreline and an area of about $112,979 \mathrm{~m}^{2}(=11.3 \mathrm{ha})$ of flat beach terrace were created by clam garden construction. Overall, this increased the area of clam habitat by between 26 and $36 \%$; and $35 \%$ of the final area of clam garden habitat had been constructed on bedrock shelves and rocky slopes where no clam habitat had existed previously and these features still have a significant impact on today's intertidal ecosystems. Judging from measurements of clams deposited in middens that had been collected in active clam gardens, the gardens enhanced clam production despite increased harvesting pressure. Decline of traditional management practices since European contact are associated with reductions of clam growth and clam size to levels like those of the early postglacial clams; that is, the advantages of the clam gardens are being lost in the contemporary world (Toniello et al., 2019).

Although the old clam gardens may not have been maintained properly in the more recent past, or even for many generations, they still maintain a legacy of increased shellfish productivity today, suggesting that clam gardens provided a reliable source of food for past populations through time; and if emulated could do the same again.

Those who have so recently revealed this fascinating ancient technology remind us that it could be used today to provide sustainable food security with quotations like:

- “... In many marine systems, current management approaches have demonstrably failed to halt or reverse fisheries declines, in part due to the inadequate recognition of the strong links between social and ecological processes. Ancient clam gardens and their governance by coastal communities are an example of an adaptive strategy that likely enhanced regional food security and thus conferred resilience to these coupled human-coastal ocean ecosystems. ... The archaeological record is clear; abundant shellfish have supported large populations of people on the Northwest Coast through history. This new evidence helps emphasize the value of incorporating traditional management techniques into future strategies towards sustainable solutions, contributing to local food security efforts globally ..." (Groesbeck et al., 2014).

- "... Clam habitat expansion facilitated by clam garden construction encouraged a sustainable and abundant food source in the past and could do so again in today's changing environmental conditions ..." Lepofsky et al., 2020).

It is intrinsically interesting that the First Nations Peoples of British Columbia have been harvesting shellfish from specially-constructed clam gardens for several thousand years. But those of us who look to shellfish to sequester atmospheric carbon are mainly concerned to hold up this ancient activity as an example for a cheap, simple and locally managed procedure that could be used tomorrow on shorelines around the world. The expectation being that enhanced 
cultivation of molluscs and crustacea of all sorts in such gardens for the sake of their ability to sequester atmospheric $\mathrm{CO}_{2}$ into crystalline $\mathrm{CaCO}_{3}$ will also provide a sustainable source of food, as well as improved coastal defences.

\section{What is aquaculture?}

As we have seen in the previous section, the origins of real aquaculture date back several thousand years with the First Nations' suite of activities including clam gardens, fish traps and fish weirs, coupled with their self-imposed management of harvesting to maintain resource sustainability. When we turn to recorded history there is not much mention of shellfish mariculture until the twentieth century; in earlier historical times attention was focussed on fish farming, and this was often of freshwater fish. Until very recently, marine resources remained as capture fisheries and foraged coastal resources; the responsibility of the fishermen and fishwives (in the original archaic meaning) of coastal communities.

Beveridge \& Little (2002) discuss what aquaculture is and how it differs from fisheries (hunting) and agriculture. They offer a number of definitions that include what they consider to be key components: (a) some measure of care or cultivation to improve the yield of aquatic organisms by deliberate manipulation of their rates of growth, mortality and reproduction; and (b) the concept of ownership of access and exploitation rights. The Food and Agriculture Organization of the United Nations (FAO) introduced a definition of aquaculture which meets these criteria and reduces confusion with capture fisheries: "... [aqualculture is] the farming of aquatic organisms including crocodiles, amphibians, finfish, molluscs, crustaceans and plants, where farming refers to their rearing to their juvenile and/or adult phase under captive conditions. Aquaculture also encompasses individual, corporate or state ownership of the organism being reared and harvested ..." (Rana, 1997).

This definition does not cover all situations, of course. Many forms of aquaculture are based on the exploitation of multipurpose water bodies, for example irrigation water storage ponds, rice paddies, etc, which might be 'common property'. So, Beveridge \& Little (2002) suggest the key criteria distinguishing farming from hunting to be:

- Intervention(s) to increase yields.

- Defined ownership of stock or controls on access to and benefit from the activity.

- The end purpose is not specified; meaning that rearing shellfish for food, and rearing shellfish to sequester atmospheric $\mathrm{CO}_{2}$ would both be regarded as aquaculture.

It remains the case, though, that differentiating between hunting and farming in the aquatic environment is difficult, largely because the range of methods used in exploitation of those environments has not been adequately documented. A suggestion intended to aid comparison of historical aquaculture with contemporary practices from an ecological standpoint, is the acceptance of a further set of three definitions that relate to resource use:

- Intensive aquaculture. Comparable to intensive terrestrial farming, here the aquatic animals are almost exclusively reliant on the farmer providing them with a supply of nutritionally-balanced, high protein food, which is generally based on fishmeal, fish oils and mineral supplements (Heilweck \& Moore, 2021).

- Semi-intensive aquaculture. Which involves supplementing the level of natural food in the system in some way. The supplementary feed may be compounded from by-products or wastes from agricultural activities, but could be cultivated in situ by arranging for highnutrient waters to be mixed with low-nutrient water (see the discussion of perpetual salt fountains and Fig. 10 in (Heilweck \& Moore, 2021). 
- Extensive aquaculture. In extensive aquaculture, the aquatic animals must rely solely on available natural food, such as the plankton (alive and dead), biological detritus and nonbiological suspended matter (all together referred to as 'seston').

These definitions are useful enough to be applicable to the diversity of aquaculture practices to which reference is made in this book. They offer a general guide to the relative use of tangible environmental resources, which are known as 'ecosystem goods' and include nutrients, water, light, and energy. The intensity of aquaculture production methods has implications for use of 'ecosystem services', which are the activities provided by other components of the ecosystem, such as supplies of oxygen and recycling of wastes, and the consequential extent of intervention (by the farmer) that may be required. The more external food that is supplied per tonne production, the greater the wastes and the greater the demands on the environment to disperse and assimilate these wastes (balancing these services is discussed by Heilweck \& Moore (2021)).

Beveridge \& Little (2002) also discuss the origins of aquaculture practises, likening it to the origin of agriculture and, in particular, highlighting Colin Tudge's quotation: "... People did not invent agriculture and shout for joy. They drifted or were forced into it, protesting all the way ..." (Tudge, 1998), who argues against the traditional view that agriculture began in the Middle East around 10,000 years ago. He believes that this view under-plays the importance of 'proto'farming activities, throughout much of our previous two million year history, to persuade more food out of the environment, especially from the late Paleolithic onwards (from about 40,000 years ago). The traditional view is that hunter-gathering is hard, and that farming made life easier. Colin Tudge turns this notion on its head; asserting that farming is now, and always was, hard work and to be avoided unless absolutely necessary (Tudge, 1998).

Tudge also contends that when food supplies improved through upturns in abundance of game or more clement weather or death or emigration of people, the prehistoric communities returned to what they enjoyed best: hunting and gathering. Beveridge \& Little (2002) point out that different peoples adopted farming activities at different times, and some cultures, such as the Chinese, developed agriculture independently, others (most of the continent of Europe) learned from neighbours or colonisers, while a few appear never to have acquired agriculture at all, such as the Indigenous Australians (humans first populated the Australian continent at least 65,000 years ago).

Beveridge \& Little (2002) also claim that there is good evidence in aquaculture for Tudge's theory of people opting in and out of plant and animal cultivation according to their needs (Beveridge \& Little, 2002), being in many respects similar to agriculture, aquaculture too began in different ways in different societies, both agriculture based, and capture-fishing based, and developed from there to the present day:

- Transplantation of fertilised eggs or juvenile animals, like any of the many contemporary shellfish hatcheries intended to replenish and/or expand harvested stocks.

- Entrapment of fish in areas where they could thrive and be harvested as required, like the stone fish traps and fish weirs of many indigenous communities.

- Environmental enhancements, such as development of spawning areas, enhancement of food, exclusion of competitors or predators, etc., like the clam gardens of British Columbia's First Nations Peoples.

- Holding fish and shellfish in systems like ponds, cages, and pens, until their biomass and/or food value improve, like any present day salmon or whitefish farm. 
On its own, each of these activities might be considered as no more than stock storage and/or stock enhancement and therefore fall under a 'managed fisheries' definition. But they can be woven into much more sustainable activities, and they were most likely implemented on a local scale by small communities that undoubtedly exhibited the concepts of community ownership and controlled access. These early 'proto-aquaculture' stages also feature low consumption of energy.

One other term used in aquacultures is ranching, which is used to describe the release of juveniles into the wild, only to be recaptured later as adults. The term has been used in relation to crustacean farming (Wickins \& Lee, 2002).

Although the details of fish farming are beyond the scope of this book, this activity is so bound up with the historical origins of aquaculture effort that we have to consider it, at least in outline, to help explain how aquaculture might have first developed. According to Beveridge \& Little (2002), “... aquaculture began in various parts of the world and at various points along the aquatic food supply line, between water and plate. The farming of fish and shellfish is generally considered to be an activity of settled societies, originating among both fishing and wetland farming cultures as well as at points of trade ...."

I have indicated above that archaeological research demonstrates the importance of shellfish and fish in early (migrating) hunter-gatherer societies. It may therefore be assumed that when these communities settled and increased in size, foraging and fishing may have been insufficient to satisfy demands for shellfish and fish (usually called finfish to distinguish from shellfish), respectively, resulting in the development of the simpler proto-aquaculture stock management techniques.

“... Many proto-aquaculture activities relied on some sort of holding facility. The simplest to construct would have been earth ponds. In some parts of the world these would have been little more than mud walls constructed to temporarily hold water and fish following the seasonal flooding of a river. Such systems are still in use in some parts of the world today. The 'whedos' or fish holes of Benin are one such example ... The practice of communal construction of weirs on small rivers and streams in Asia to store water outside of the monsoons principally to ensure adequate irrigation for wet rice cultivation ... is also common. Attempts to increase fish yields would have been a logical next step ... shortterm storage of catches until there were sufficient fish or shellfish to make a journey to market worthwhile; the transport of live fish to market; the holding of catches until prices improved. These strategies are still seen among fisher folk today: modified traps, netted off shallow areas of lakes, cages of the sort still seen in parts of Indonesia, traditional floating cages used in the Great Lake area of Cambodia ..." (Beveridge \& Little, 2002).

The practice of harvesting the larger fish in a holding pond, leaving the smaller fish to remain as broodstock is a common procedure the world over. It is a natural step from there to primitive fish farming.

\section{Fish and shellfish in recorded history}

Proto-aquaculture activities have been recorded in many parts of the ancient world, including Egypt, China and Mesoamerica. The earliest records seem to be from ancient Egypt where a 4,000 year old bas relief in a tomb shows what appears to be a nobleman fishing, probably for tilapia, in an artificial, drainable pond (Bardach et al., 1972). This was the simplest protoaquaculture; native tilapia being transferred from rivers to captivity in the ponds and involving little management. Rod and line fishing is believed to have been common among all classes in 
Egypt at that time, but the fishing activity of the nobility was limited to their ponds as it was more of a religious ritual, associated with death and rebirth, rather than a way of catching food. On the other hand, Roman writers of the day imply that fish was of great importance in the Egyptian commoners' diet; saying that "... the Nile supplies the native ... with fish freshly caught [and] an unfailing multitude for salting .... all Egyptians in the Nile Delta possess a net with which, during the day, they fish ..." (Beveridge \& Little, 2002). This difference between nobles and commoners in the relevance of fish to the diet is something that emerges again in medieval Europe.

Modern aquaculture began in Egypt in the mid-1930s with the introduction of the common carp in two research finfish farms. According to FAO Fact Sheets (Salem \& Saleh, 2010), 14 different species of finfish (species of carp, catfish, meagre, mullet, seabass, seabream, and tilapia) and two species of crustacean are currently farmed in Egypt. The shellfish being penaeid shrimps (Penaeus spp.) (Kungvankij, 1984; Briggs et al., 2005) and the giant river freshwater prawn (Macrobrachium rosenbergii) (FAO, 2020a).

Fish has almost always been important in the Asian diet and China's wetland-based agriculture was a strong incentives to develop inland fish farming as an integrated polyculture aquaculture, and China is widely regarded as the cradle of aquaculture. Its history is carefully reviewed by Beveridge \& Little (2002). An historical highlight is a document published 2,500 years ago (by the statesman Fan Li) that describes carp (Cyprinus carpio) farming in sufficient detail to show that aquaculture, as a 'semi-intensive' monoculture, was well-established by this time. There are other written records, dating from the period 2,200 to 1,720 years ago, telling of the integration of carp culture with that of aquatic plants and vegetables (Yang, 1994). The most complex integrated aquaculture system was the fishpond-dyke-mulberry system (Ruddle \& Zhong, 1988), which supplied live fish, fruit, and leaves for silkworm cultivation.

With the possible exception of China, not many of today's aquaculture industries have a history extending back more than 30 or 40 years; they simply do not owe much to older traditions or technologies. The exception, China, has been the world's top (inland) fish producer for many years, and China's aquaculture is much more diverse than all other countries in terms of farmed species, of which there are over 200, and farming systems and methods. Nevertheless, until the founding of the People's Republic of China in 1949, the harvest of farmed fish was only a fraction of that obtained from capture fisheries. A 50-fold growth in production of cultivated freshwater fish occurred as a result of the political, economic, technical and demographic changes in 1949. Among those changes was the construction of over 82,000 man-made bodies of water as reservoirs for hydropower, flood control and irrigation purposes, amounting to an increase in the inland water surface area by over 2 million ha (De Silva et al., 1991). Most of these were used for farming carp, initially with wild-caught fry but techniques for spawning Chinese carp were developed in the late 1950s. Later progress of the mixed economy in the PRC incentivised greater increases in productivity of inland fish, although aquaculture was rare elsewhere in Asia at the time.

Today, over 700 species of freshwater fish and 60 species of marine freshwater migratory fish occur in the inland waters. Inland capture fisheries are still important, but the most commonly farmed species are several species of carp, bream, chub, and mandarin fish (Synchiropus splendidus; a small, brightly coloured saltwater aquarium fish), as well as soft-shelled turtle (a delicacy, particularly as turtle soup, in many parts of Asia). Farmed shellfish include (Bernal \& Oliva, 2016; FAO, 2017): 
- Fresh-water shrimp/prawn (Macrobrachium rosenbergii) (FAO, 2020a), fresh-water mussel (Margaritifera margaritifera, reared to produce cultured pearls (FAO, 1983; URL: https://en.wikipedia.org/wiki/Freshwater pearl mussel]).

- River-snail (Cipangopaludina chinensis), eaten for its meat throughout China, its shells are abundant in Mid-Late Neolithic archaeological sites in the Guanzhong Basin of Northwestern China (Li et al., 2013).

- The Chinese mitten-handed crab (Eriocheirn sinensis). Cultivation begins from a larval stage that can adapt to freshwater, reared in a nursery until they become 'button-sized' juvenile crabs and then grown to market size in ponds, pens in lakes, or rice paddies. Paddy culture has increased rapidly in recent years as an environmentally friendly production approach that benefits both the crabs and the rice (Liu \& Chen, 2002).

Marine aquaculture has expanded recently, mostly in shallow waters, shoals and bays, and using (according to species) raft culture, net cage culture, vertical culture, seabed 'seeding', stone adhesion culture and pond culture. Farmed organisms include several fish species and various shellfish including shrimp (Penaeus chinensis), oyster, mussel, scallop, several clam species, abalone, crab, kelp and Porphyra sp., the edible red alga known as laver seaweed (Bernal \& Oliva, 2016; FAO, 2017). Until recently, wild marine fish and shellfish resources in other Asian countries with extensive coastlines were sufficient to supply the needs of their populations; both freshwater and marine aquaculture are being developed extensively throughout Asia and Africa. Because of travel restrictions and bans on mass gatherings caused by the COVID-19 pandemic, World Aquaculture Society's Conferences planned for 2020 have been rescheduled to 2021; the Asian Conference in Singapore in June [https://www.was.org/meeting/code/WA2020], and Aquaculture Africa in Alexandria, Egypt, in December [https://www.was.org/meeting/code/AFRAQ20].

Pre-Hispanic Mesoamerican (Aztec) cultures that flourished from AD 1300 to AD 1521 developed several integrated wetland agriculture-with-aquaculture systems around lake margins in the Valley of Mexico. Although it is believed that these were once used to enhance fish storage and/or production this plays no part in the present-day systems that survive. (Micha \& Chavez, 1997; Little \& Edwards, 2003). In the present day, South American countries are major producers and exporters of both capture-caught and aquaculture fish and shellfish; Chile and Brazil being two of the largest intensive fish producers in the world. However, while Chile relies primarily on marine fish, Brazil leads in continental production (Valladão et al., 2018; FAO, 2020b). Production of native fish is beginning to overtake production of non-native species in some countries. In particular, the 'black pacu' (Colossoma macropomum), which is found in most rivers and streams in the Amazon and Orinoco river basins, is commonly farmed because farming black pacu competes well, economically, with tilapia production in South America.

There is no tradition of aquaculture in the Caribbean region, in contrast to capture fisheries, but developments are taking place. In 2014, the State of World Fisheries and Aquaculture (FAO, 2014), published by the Food and Agriculture Organization of the United Nations, said that world food fish aquaculture production expanded at an average annual rate of $6.2 \%$ in the period 2000 to 2012 but over the same period in Latin America and the Caribbean the increase was 10\% per annum. According to (Myvett et al., 2014): “... The practices mainly involve the use of ponds to culture such species as penaeid shrimp (Penaeus spp.), tilapia (Oreochromis spp.), carp (Ctenopharyngodon idellus, Hypophthalmichthys nobilis, Hypophthalmichthys molitrix) and cachama [the local name for black pacu] (Colossoma macropomum). Also, there is long line culture for algae (Eucheuma spp. and Gracelaria spp.) in St. Lucia and the mangrove oyster (Crassostrea rhizophorae) in Jamaica." (Myvett et al., 2014). A mangrove oyster farming system has been operating successfully in Cuba for many years (Nikolić et al., 1976). 
The Caribbean Regional Fisheries Mechanism (CRFM) has identified the promotion and development of aquaculture as one of its priority programme areas and has established an Aquaculture Working Group tasked with identifying constraints to aquaculture development and making recommendations (Myvett et al., 2014). This CRFM Technical \& Advisory Document considers some of the species that might be grown in the Caribbean culture systems (and elsewhere, also), they are:

- Marine fish. Several of the marine fish species occurring in the seas around the Caribbean islands could be cultured in floating net cages. Sea temperatures are ideal and the water is clean and good quality. Groupers are well suited to this this type of mariculture, which is well developed in Southeast Asia (Yang et al., 2014).

- Turtle farming. Sea turtle populations in the Caribbean region have been declining for a long time as taking turtles for their meat, shells and eggs has depleted stocks drastically. Turtle farming might be based on collection of eggs, or hatchlings, in the wild, though this could reduce the recruitment to the already dwindling stocks of wild sea turtles (unless the farms can be stocked with daytime hatchlings which would otherwise be taken by seabirds). Turtle farmers believe that the damage done through collection of eggs in the wild is compensated by their restocking efforts. There is a turtle farm located in the Cayman Islands, where the green turtle is cultured in large ponds, but it remains controversial (Bale, 2017), although turtles are caught throughout the Caribbean and there is a market for the meat. Experience elsewhere is that sea turtle farms, whether for captive breeding or ranching, cannot be shown to be directly beneficial or proved to be detrimental to conservation of wild populations. What can be demonstrated is that they are very expensive, require advanced technical knowledge, and are of uncertain economic viability (Haitao et al., 2007).

- Seaweeds. The technology for mariculture of seaweeds is so well known in most cases that it needs only adaptation to local conditions and is simple and well suited for unskilled coastal communities. Initial investment in materials and supplies is minimal and the installations required can be easily repaired and replaced. There is good potential for culture of Gracilaria debilis, which is used for food grade agar production as a gelling agent, for local consumption and export (Veeragurunathan et al., 2019). It is also possible that culture of seaweeds producing carrageenan (also widely used for gelling, thickening, and stabilising products in the food industry) such as Euchema sp. and Hypnea sp. could also be undertaken. These seaweeds are often found in the Caribbean, but the natural stocks are insufficient to sustain commercial harvesting, though certainly sufficient as a source of 'seeds' for mariculture.

- Cockle culture technology is simple, cheap and well suited for use by unskilled local communities. Small seed cockles, collected from natural beds, are transferred to growing beds in shallow bays, being scattered as evenly as possible. Harvesting is done eight to nine months after sowing over a period of two or three months. Yields can be in the order of 35 to 40 t ha $^{-1}$.

- Queen Conch (Strombus gigas) stocking. Conches feed on a variety of plants including manatee grass and turtle grass which grow well on sandy bottoms in relatively silt-free water. The animals are usually found at depths between 3.5 and $16 \mathrm{~m}$. Although they emphasise that improved management of the natural resource is essential, Myvett et al. (2014) suggest a hatchery could re-stock the many areas depleted by overfishing. Unfortunately, experience with this practice is not good; Stoner (2019) suggesting that "... every effort should be made to conserve wild populations. Hatchery production for stock restoration should be considered a last resort."

- Oyster and mussel culture in the sea. Farming oysters and mussels in the sea can be organised as smallholder activities that do not normally require high investments per unit 
area of production. A disincentive is that the smaller islands in the Caribbean do not have enough sites with sufficient planktonic food in the water for this to be a worthwhile mariculture development. It is also discouraging that only small quantities of these bivalves are consumed in the islands, so production volumes would have to be scaled to suit processing and transport capabilities. Nevertheless, the blue mussel (Mytilus edulis) aquaculture industry in Chile has solved all these problems of integration and could be a model worth following (Gonzalez-Poblete et al., 2018).

- Pond based aquaculture. The advantage of constructing intensive mariculture systems on land is that they can be sited so far from the sea that the risk of storm damage is minimised. The trade winds, which blow northeast from the coast of Africa across most of the Caribbean at more or less constant speeds of 24 to $32 \mathrm{~km} \mathrm{~h}^{-1}$, could be harnessed with new windmill technology to pump seawater into raceway ponds (see Moore, 2021, Fig. 6). Penaeid shrimp, marine reef food fish, like snappers and groupers, and ornamental fish are suitable for cultivation in land-based intensive mariculture facilities. Yields of shrimps in the order of $2 \mathrm{~kg} \mathrm{~m}^{-2}$ can be expected from such raceways, three times per year.

FAO's Fishery and Aquaculture Country Profile for the United States of America (FAO, 2019) reports that the majority of the seafood consumed in the USA originates from imports, and in 2017, the USA was the world's leading importer of fish and fishery products. US capture fisheries and aquaculture occur in many of the country's coastal waters, rivers and lakes. Some fishing also takes place in the exclusive economic zones (EEZs) of other nations, and on the high seas, such as tuna caught in the Western Central Pacific. The two main capture species are Alaska pollock (Gadus chalcogrammus) caught in the Pacific Ocean and Bering Sea, and Gulf menhaden (Brevoortia patronus) caught in the Gulf of Mexico.

Inland commercial fisheries of the US are limited to the Great Lakes and a few major rivers. Aquaculture production declined from a peak level of over 600,000 tonnes in 2004, due mainly to a decrease in farming of channel catfish (Ictalurus punctatus), which is North America's most numerous and widely distributed catfish species. But despite this decline, channel catfish farming still dominates freshwater aquaculture, with rainbow trout (Oncorhynchus mykiss) representing only $8 \%$ of total production. US aquaculture produces food fish, ornamental fish, baitfish, molluscs, crustaceans, aquatic plants and algae, with some reptiles such as alligators and turtles.

Crayfish farming, of red swamp crawfish (Procambarus clarkii) comprises about a quarter of total freshwater aquaculture production. Crawfish, as they are called locally, are cultivated and consumed for food in several southern states but Louisiana dominates the crawfish industry of North America and includes the related species Procambarus zonangulus occurring in Louisiana that accounts for about $15 \%$ of production. The downside of crawfish farming is that in areas where it has been introduced $P$. clarkii is highly invasive and, more importantly, is a potential vector for the crayfish plague (caused by Aphanomyces astaci, a fungus-like 'water mould' belonging to the Phylum Oomycota).

Crayfish plague was introduced into Europe in the 1960s along with American freshwater crayfish species and resulted in many indigenous freshwater crayfish populations being diminished or even eliminated (FAO, 2016). US aquaculture also produces shrimp in brackish ponds in South Carolina, Texas, and Hawaii. The US also farm-raises mollusc species such as abalone, oysters, clams, and mussels. Molluscs are grown in almost every coastal area of the US and are produced using various systems (FAO, 2019). 
The US Department Of Agriculture (USDA) has several important programmes to assist the aquaculture industry. Details and reports are available from the USDA website at http://www.usda.gov by navigating to /Agriculture/Aquaculture.

Of particular interest are some programmes of the National Marine Fisheries Service (NMFS), which is the US federal agency responsible for the stewardship of national marine resources (its parent agency is the National Oceanic and Atmospheric Administration (NOAA; https://www.fisheries.noaa.gov/) of the US Department of Commerce. NMFS activities include: The National Sea Grant College Program (http://www.seagrant.noaa.gov/), that supports aquaculture in many topic areas; and the National Ocean Service (http://oceanservice.noaa.gov/), which administers Federal Coastal Zone Management Act funds for aquaculture facilities in the coastal zone.

The common carp (Cyprinus carpio) was undoubtedly vital to the development of aquaculture in continental Europe during most of the past two thousand years. The Romans are documented as being among the first to build coastal aquaculture ponds, most likely before the end of the second century BC. Excavating substantial areas of fishponds ('piscinae') at their villas was common among members of the nobility, partly for the purpose of holding live food fish, but also as a demonstration of wealth and status, a practice that persisted for several centuries. But common people also built freshwater and saltwater ponds ('dulces') for food production and income generation, which were stocked with coarse fish and salmonids, eel, mullet, turbot and sea bass. Classical Roman literature gives the impression that the keeping of fish in artificial ponds was commonplace throughout the Mediterranean provinces of the Roman Empire (Beveridge \& Little, 2002).

During the 1st and 2nd centuries AD the common carp was imported from the Danube and the practice of common carp aquaculture developed by the Romans gradually spread westwards across the continent of Europe, although it did not reach England until the late 14th century. In central and western Europe, fish farming was developed in the first instance by the monastic orders in order to ensure supplies of fish for days when eating of meat was forbidden. Subsequent pond aquaculture developments in continental Europe were often practiced in modified floodplains where soils were too poor to sustain agriculture because they were likely to flood.

In medieval England, pond fish culture was also used by the post-1066 AD Norman rulers to help consolidate their political power and the ecclesiastical power and influence of their church. The monasteries were the repository of knowledge throughout the Middle Ages, and that included knowledge of carp cultivation. Mill ponds, essential 'header tanks' for the waterwheels needed to drive the industry of the day were usually stocked with fish. Wealthy landowners also had such ponds constructed, so the privileged classes could exercise their preference for fresh rather than salted fish, and widespread development of carp farming ponds occurred throughout much of continental Europe during the 14th to 16th centuries (Hoffmann, 1996; Beveridge \& Little, 2002).

With the dissolution of the monasteries by Henry VIII in the 16th century in England, many monastic fishponds were abandoned, though a few wealthy freemen began to create aquaculture ponds during the latter part of the medieval period. There is even evidence that in the Forest of Arden, Warwickshire (the forest in Shakespeare's As You Like It), wealthy peasants owned such ponds, and that part of their produce was sold. There is also evidence of fishmongers in the 1350s in London feeding fish they kept in ponds for sale, though the practice was never widespread. In post-medieval times, keeping common carp in ponds became popular 
for a while among land-owning nobility, the fish being used for both domestic consumption and sale (Currie, 1991). However, there was a decline in eating freshwater fish such as carp, bream and perch during the 17th and 18th centuries. Indeed, the best known cookbook in the Englishspeaking world, Mrs Beeton's Book of Household Management, first published in 1861, states that "freshwater fish are seldom purchased" (Chambers \& Gray, 1988; Beveridge \& Little, 2002).

Pond fish farming in Germany, France and Central Europe declined from the late 16th century onwards and did not recover until trout culture developed in the mid-19th century. Fish was always more expensive than meat, and consumption of fish declined during the 17th century, first among the nobility and later among the middle classes. In 18th century Europe fish farming withered and died (Beveridge \& Little, 2002).

For most of recorded history, therefore, aquaculture has meant the production of fish in freshwater ponds or coastal marine lagoons. Fish for religious purposes, fish for the nobility, very occasionally fish for the people of lower social standing, if they could afford it. Throughout our history the hunt for animals on land has been a noble pursuit for the gentry.

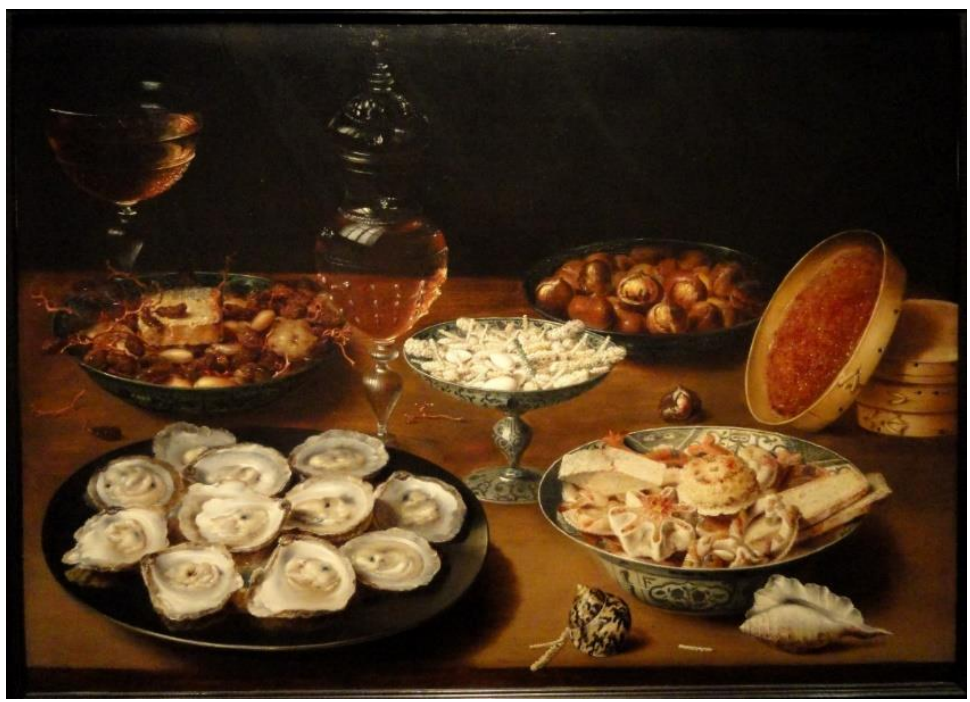

Fig. 5. Dishes with Oysters, Fruit, and Wine, by Osias Beert the Elder, probably the most important stilllife painter in Antwerp during the early seventeenth century. This oil on panel still-life was painted about 1620-1625. The painting is in the National Gallery of Art, Washington DC, USA. Photo credit Daderot; image ID DSC09953.JPG. Creative Commons CC0 1.0 licence.

Fishing, the hunt for fish on the storm-tossed high seas, has been something that common people do, just to stay alive (Sahrhage \& Lundbeck, 1992). And for most of recorded history, with a few notable exceptions, aquaculture was rarely applied to shellfish. Despite the ancient example of the clam gardens of First Nations peoples, shellfish farming before about 1950 was insignificant. Shellfish were delicacies that were collected from their natural habitat; foraged usually by the weaker, younger or older members of the families of the fisherfolk who were out on the high seas catching fish, all for sale to the gentry who could afford to load their tables with fine dishes filled with food (Fig. 5).

As populations increased and became concentrated in towns and cities, demand also grew, foraging became more intensive and shellfish stocks were overfished, in some cases close to extinction, like so many other targets of our capture fisheries (Clover, 2005; Hilborn \& Hilborn, 2012). The prime shellfish example of this is the history of the oyster through the 19th century and into the early 20th century. 


\section{Oyster and scallop dredging on both sides of the Atlantic in the 19th century}

We have seen that oysters have been an important subsistence food for humans since the Neolithic period, although today they are considered by many to be a luxury delicacy. At the end of the 17th century and into the early 1800 s, oysters were eaten mainly by the wealthy, except in local harvesting areas. However, by the mid-1800s, a surge in demand caused increase in production, and consumer prices for oysters dropped substantially; oysters became cheaper to purchase than meat, poultry, or finfish and oysters were eaten by people at all economic levels (MacKenzie, 1996).

The issue of The Illustrated London News of 12th August, 1843 included an article entitled 'Oyster Day'that reported: “... August 4 was, in metropolitan parlance, 'Oyster Day', i.e. the day on which oysters are first brought into the London market at Billingsgate ... There were fifty sail of vessels at market from Rochester, Whitstable, Essex, and the Cheyney rock, near the Isle of Sheppy ...". A few years later, 1861, The Illustrated London News showed the excitement surrounding a street vendor in London on Oyster Day (Fig. 6).

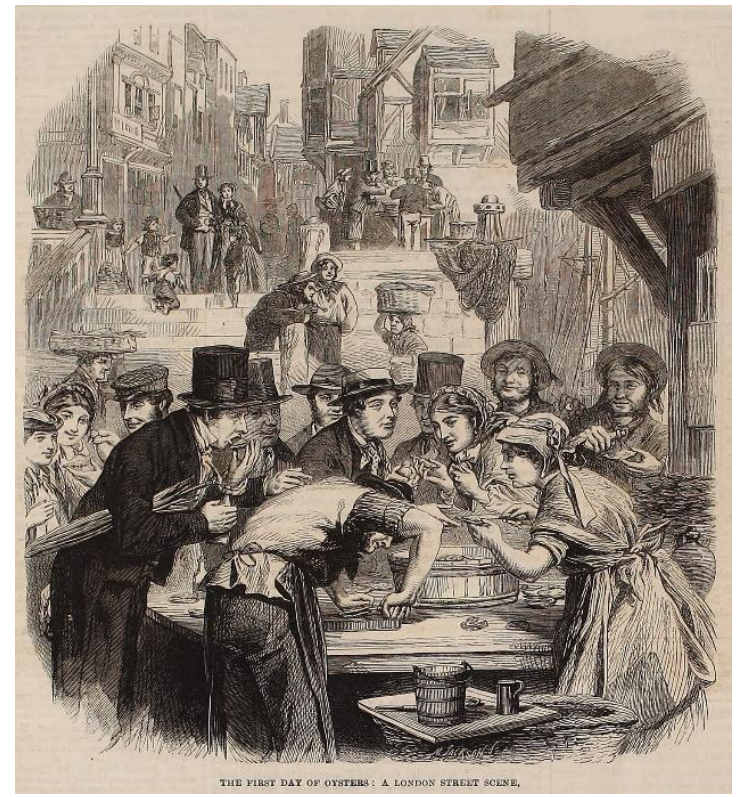

Fig. 6. The first day of oysters: a London street scene. Published in The Illustrated London News of 1861. Showing people gathered around the stall of an oyster seller, some opening oysters, others eating them. Taken from Old Book Illustrations [https://www.oldbookillustrations.com/illustrations/first-dayoysters/] under a Creative Commons 4.0 License.

Those oysters that arrived at Billingsgate Market on Oyster Day (Fig. 6) were dredged from the river estuaries and seas off England's southern coastline by fishing smacks (Fig. 7).

One such river was the River Colne, a small river in England that runs through Essex. In fact, the Essex Colne (there are other rivers with that name in England) passes through the town of Colchester, once a Roman fort and settlement (called Camulodunum), which is the site of Britain's earliest known Christian church and is the earliest recorded town in England. Oysters are native to the river Colne and Colchester's oysters have been famous since before Roman times. Downstream of Colchester the Colne estuary joins the North Sea near Brightlingsea, just North of the Thames estuary. 
Dredging oysters is a long-established occupation of the fishermen of Essex, and by the end of the 19th century they were using iron-framed dredges with collection nets. The sailing smacks might tow 4 to 8 of these dredges across an oyster ground, gathering, besides oysters, much rubbish and gastropod pests/predators of the oyster from which the marketable oysters had to be sorted. The rubbish was thrown overboard, but the pests (mainly slipper limpets, Crepidula fornicata, but including tingle borers, Ocenebra erinacea or the American whelk tingle Urosalpinx cinerea, and dog whelks) were kept on deck to be dumped ashore when the day's work was done; an unceasing struggle to keep the oyster grounds clean (Fig. 7).

The slipper limpet is a non-native species in British waters; it was probably introduced from its natural habitat on the Atlantic coast of the USA in about 1870 with consignments of American Bluepoint oysters imported for re-laying in English waters (Cole, 1942). Crepidula can starve and smother native shellfish, competing for food and space as well as drilling holes through bivalve shells to access the soft tissues within. Damage to shellfish by slipper limpets can make oysters, mussels and scallops impossible to sell.

Slipper limpets are now established in the waters of South England and South Wales and have severely diminished oyster stocks. Crepidula eggs are deposited in capsules from which fully formed juveniles emerge. There is no free-swimming larval stage, so infestation of new areas requires transport by human activities. Today, it is an offence to use slipper limpets as bait for fishing or to release them to the sea in UK waters [https://www.gov.uk/government/news/slipperlimpets-not-permitted-to-be-used-as-bait-or-disposed-at-sea].

In the early days, all hauling of dredges was done by hand, and between 30 and 100 smacks of up to 15 tons displacement dredged the Colne estuary fishery. The nearby Blackwater and Crouch rivers had extensive oyster layings worked by other dredgermen. In the mid-nineteenth century the railways spread throughout Britain and brought fast transport for perishable goods like fish and shellfish, so all branches of trade in fresh foods expanded considerably as the steam locomotives of the railways brought the growing populations of major cities within reach.

Expanding markets entailed expansion of the fishing fleets to meet the demand; more boats, bigger boats, and deeper dredging over an ever widening area. The Aldous shipyard of Brightlingsea built thirty-six big fishing smacks of 20 to 40 displacement tons between 1857 and 1867. Harris shipyard at Rowhedge and Harvey shipyard at Wivenhoe built a good number and more were launched on the river Blackwater. These smacks were the deep-sea trawlers of their day and they made up the most adventurous fleet of fishing vessels ever to sail from Essex, voyaging far out to sea for oysters and scallops.

Rich oyster beds were discovered off the island of Jersey in 1787 and within a few months over 300 smacks from Essex, Shoreham, Enisworth and Faversham were working there, and continued through the Napoleonic wars. Later, a fleet of 60 Essex fishing smacks would sail there each spring and carry on dredging through all hazards. The Jersey fishery declined during the eighteen-forties and became exhausted by 1871 (Leather, 1991). The Essex dredgermen went elsewhere.

Leather (1991) describes it like this:

"... Their quest for oysters and scallops led them at various times to work the Inner Dowsing and the Dudgeon banks [off the south Lincolnshire coast], landing catches at Grimsby or Blakeney in north Norfolk, the Ness grounds, stretching from Orfordness to Cromer in Norfolk, the Galloper and Kentish Knock areas of the North Sea, and the Terschelling and Hinder banks off the Dutch coast, landing catches at Brightlingsea. In the 
English Channel they dredged the Goodwin, Sandettie and the Varne grounds besides those on the French coast at Caen Bay, Dieppe, St Valéry-sur-Somme, Fécamp, Calais and Dunkirk, using Ramsgate, Dover, Shoreham or Newhaven to land catches."
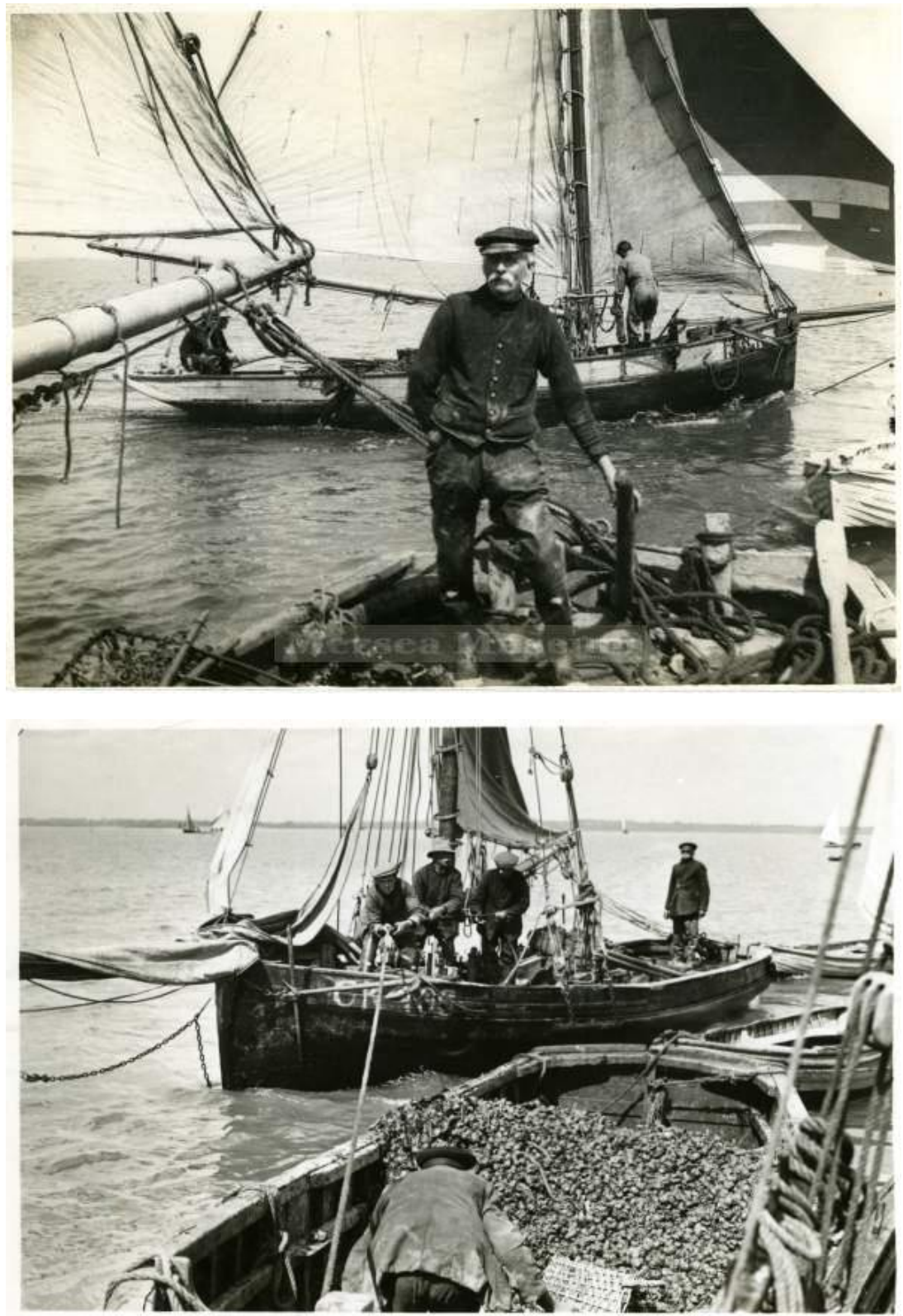

Fig. 7. Dredging oysters in the River Colne. Top: Oyster dredging smacks at Brightlingsea going out for oysters. William Francis of Brightlingsea, foreman of the Colne Fishery Company, at the helm of the company smack NATIVE. Photo by Douglas Went, dated 1928, image ID BOXB5_017_031. Bottom: The Colne Fishery Company smack NATIVE hauls alongside an oyster skiff to dump thousands of slipper limpets dredged from the oyster grounds in the course of a tide's work. The NATIVE probably intends to anchor when the despised limpets are unloaded. Photo by Douglas Went, dated 1936, image ID BOXB5_017_029. Both images from http://www.merseamuseum.org.uk/.

Down Channel, towards the Atlantic, the Essexmen dredged West Bay, off West Dorset's Jurassic Coast, and occasionally the Cornish Fal and Helford rivers were visited by the dredgermen. 
“... Others sailed round Land's End to work on the south Pembrokeshire coast, based at Swansea and Bangor, and southern Ireland, north west Ireland and the Solway Firth [off the south west coast of Scotland] regularly saw the rakish Colne topmasts ..." (quoted from Leather, 1991).

Oyster and scallop dredging at this intensity (truly 'over-fishing') caused widespread stock exhaustion of both oysters and scallops. The flourishing oyster fisheries they exploited at Swansea and Cardigan Bays in Wales, Largo Bay in Fife, Scotland, in the Solway Firth and off north Norfolk were rapidly worked out by fleets of fishing smacks from Colne. It's interesting to note that in the present day many of the locations mentioned in the quotations above are protected conservation areas and/or restoration areas (Table 5).

Table 5. Website URLs of a few of the conservation and restoration projects underway at present

Cardigan Bay - Natural Resources Wales

[https://cdn.naturalresources.wales/media/687994/cym-cardigan-bay-reg-37-report-2018.pdf]

\section{Solway Firth Marine Conservation Zone}

[https://assets.publishing.service.gov.uk/government/uploads/system/uploads/attachment data/f ile/915681/mcz-solway-firth-2019.pdf]

Offshore and English inshore Marine Conservation Zones [https://incc.gov.uk/ourwork/marine-conservation-zones/]

Billion Oyster Project is restoring oyster reefs to New York Harbor in collaboration with New York City communities

[https://www.billionoysterproject.org/\#: : :text=Billion\%200yster\%20Project\%20is\%20restoring,pr eventing \%20 erosion\%20along\%20the\%20shorelines]

Oyster Restoration - Chesapeake Bay Foundation [https://www.cbf.org/about-cbf/ourmission/restore/oyster-restoration/]

Oyster restoration in the USA - The Grand Tour by the Blue Marine Foundation [https://www.bluemarinefoundation.com/2017/06/27/oyster-restoration-in-the-usa-the-grandtour/]

The Nature Conservancy oyster restoration in the US [https://www. nature.org/en-us/aboutus/where-we-work/united-states/oyster-restoration/]

New Jersey growers deliver $\mathbf{2 4 0 , 0 0 0}$ oysters for reef restoration a news report on www.seafoodsource.com.

The European Native Oyster Habitat Restoration Alliance [https://noraeurope.eu/]

... there are many more ... use your favourite search engine to search for restoration + place + organism

After the turn of the century, 1900, a series of poisoning scares raised fears regarding the safety of oysters and killed the demand for sea oysters. At least some of these fears were well founded and seemed likely to be due to the zeal of Victorian civil engineers who were keen to take advantage of the ability of filter-feeding bivalves to purify foul water. When they built the town sewer networks they were creating to collect sewage from the growing urban populations they laid their outfalls into the estuary and coastal oyster beds in the hope that they might clean up the effluent. But they didn't. 
We can't be too critical of the civil engineers of the 1830s to 1870 s because it wasn't an entirely illogical plan. Final proof of the germ theory of disease (by Louis Pasteur and Robert Koch) only came in the 1880s and viruses were first discovered in the 1890s. At the time the engineers were designing and building their sewer systems, diseases were thought to be caused by a miasma, a noxious form of 'bad air'; so, if that's what the doctors tell you, go ahead, shift the sewage downstream and get the oysters to clean it up. What's miasma got to do with oysters?

The majority of the shellfish-associated infections that have been reported over the last century have been linked to oysters, followed by clams and mussels. We now know that they have been caused by viruses, particularly Hepatitis A virus, which causes a potentially serious liver infection, and caliciviruses, which include noroviruses, and cause acute nonbacterial gastroenteritis. All these viruses are spread in human faeces; so, there really is a good reason to be more careful with your sewage. Vibrio species, which thrive in warm seawaters, head the list of bacterial pathogens associated with shellfish, several species of which can cause foodborne infection, usually linked to eating undercooked seafood as the bacterium occurs naturally in the gut of oysters and other shellfish, and in the intestines of fish that inhabit oyster reefs. The vast majority of people who develop sepsis from Vibrio vulnificus infection became ill after eating raw oysters (Berg et al., 2000; Potasman et al., 2002).

While the dredgermen of the Essex fishing fleets were busily fishing out the estuaries and waters around Britain, something very similar was happening across the Atlantic in US waters. It is an exactly parallel story to the English one. Oysters were still only eaten by the wealthy in the early 1800 s US, but a rising production through the mid-1800s brought oyster prices below that of other protein foods. In 1885, oysters cost $\$ 0.03$ each (equivalent to $\$ 0.80$ today) and by 1889 dropped to $\$ 0.01$ each (equivalent to $\$ 0.27$ today). “... The low prices meant anyone could eat them, and oysters quickly became popular with the working class as it was a rich, cheap source of protein, with major oyster markets such as New York City, Philadelphia, Baltimore, and New Orleans supplying the high demand for oysters in the US ..." (MacKenzie, 1996; Foodworthwritingfor.com, 2018). Another parallel with Britain was the growing network of railways to transport the oyster harvest throughout the US.

According to MacKenzie (1996) the eight greatest oyster dredging estuaries in the continental United States and eastern Canada, starting during the 18th century, were:

- Bedeque Bay, Prince Edward Island, Canada.

- New Haven Harbor, an inlet on the north side of Long Island Sound in the state of Connecticut in the US.

- Delaware Bay, the estuary outlet of the Delaware River on the northeast seaboard of the US.

- Upper Chesapeake Bay, the largest estuary in the US, separated from the Atlantic Ocean by the Delmarva Peninsula.

- James River, the longest river in Virginia, US; it runs into Hampton Roads where the Chesapeake Bay flows into the Atlantic Ocean.

- Apalachicola Bay, an estuary and lagoon located on the northwest coast of the US state of Florida.

- Louisiana Estuaries, which are the various estuaries through Louisiana's wetlands of the Mississippi River delta confluence with the Gulf of Mexico.

- Puget Sound and Willapa Bay; Puget Sound is an inlet of the Pacific Ocean, on the northwestern coast of the US, Washington State, that leads to Seattle. Willapa Bay is a bay located on the Pacific coast of Washington state south of Seattle. The Long Beach Peninsula separates Willapa Bay from the Pacific Ocean. 
Production from these oyster beds was so prolific through the 19th century that, because of the size of its population, New York City and its restaurants became the centre of the industry (Fig. 8). “... In fact, oysters were such a key part of New York City's economy that [oyster] shells were used for roads, cement, fertilizer, and many other items ..." (MacKenzie, 1996). Furthermore, oyster houses, or oyster saloons, restaurants that specialised in serving oysters, raw or cooked, arose throughout major cities in the US in the 19th century to meet the popular demand for oysters (Fig. 8).

It was very similar in Europe, especially in the UK, where English towns such as Whitstable and Colchester held oyster markets for the Romans. So, on both sides of the Atlantic ocean oysters became a standard part of the diet in big cities in the 19th century because of their abundance, accessibility, and low cost. Indeed, thanks to the landmark in transport history of the inaugural sailing on 4 July 1840 of the first regular Atlantic steam ferry operated by the British and North American Royal Mail Steam Packet Company (later known as Cunard Steamship Company) on the Liverpool-Halifax-Boston route, New York oysters were supplied to markets in the UK. And, as we have mentioned above, were supplied (together with their pests) for relaying in UK waters.

The creation of railroad transportation during the 19th century allowed oysters to be shipped all over the US and Europe. Canning and refrigeration were two more groundbreaking developments that expanded the oyster trade (MacKenzie, 1996).
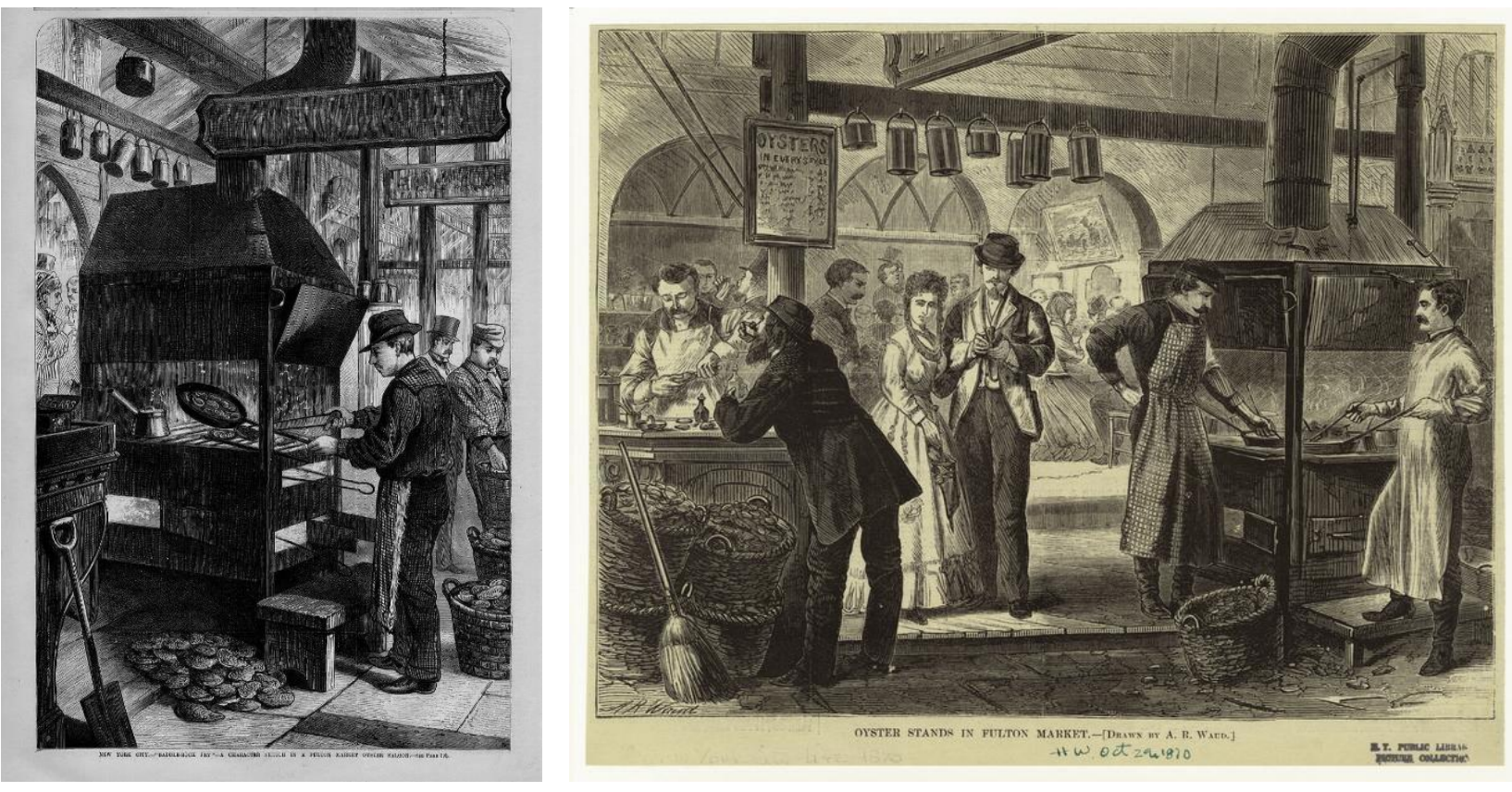

Fig. 8. Oyster saloons in the Fulton Market of New York City towards the end of the 19th century. Left: print of an oyster saloon in the Fulton Market in 1877. Right: A print from 1870s of oyster stands in Fulton Market, New York City at a time when oysters were extremely abundant and cheap (1 cent per oyster). Both images in the Public Domain. 
Oysters were eaten raw or steamed, fried, grilled, roasted, or stewed with other meats and ingredients. In London, oysters were sold at every street corner (Fig. 6) during the 19th century, and street vendors were just as common alongside the oyster saloons in New York City as well (Fig. 8); the street oyster vendors being supplanted by the hot dog stands of the New York City of today. Oysters were also very popular with the bars, gin palaces and pubs of the two cities, being so cheap they could be used as loss-leaders to stimulate sales of the more profitable beer, gin and other liquors (MacKenzie, 1996).

The ultimate similarity between the US and Europe was the overharvesting of oysters. By the time the 20th century ticked around it was becoming difficult to meet market demands. Decline in oyster stocks in the US and Europe was obvious. In the US, the oyster beds around New York and New Jersey were the first to fail. Harvesting moved to the Chesapeake Bay and other areas, only to be eventually shut down as well due to overharvesting. Add to overharvesting the effects of pests, like slipper limpets and the American whelk tingle that brought several oysters to the brink of extinction, and, further, the human infections that became associated with fresh shellfish; and almost inevitably, during the first decade of the 20th century both the demand for, and the supply of, oysters massively declined. And then, of course, the First World War killed and changed so many millions of lives for ever on both sides of the Atlantic.

\section{Bringing the oyster back to the table}

Consumption of staple foods such as beef or pork have increased over time, whereas the consumption of oysters, once a staple food for many, has decreased over time, and quite considerably decreased in recent history. Since the 1950s, consumer demand for oysters has recovered to some extent, and though natural stocks are still so depleted that natural oyster beds no longer supply much of the demand, attention has shifted to oyster farming and cultivation to produce enough oysters to meet the demands of consumers in a sustainable fashion. According to the Monterey Bay Aquarium Seafood Watch, "... Farmed oysters account for $95 \%$ of the world's total oyster consumption. Most oyster farming operations are very well managed and produce a sustainable product ..." [https://www.seafoodwatch.org/]. But in the process of developing farming operations for the oyster, the animal has lost its position as a cheap, staple food in the life and nutrition of what might be deemed the working classes.

Oysters have once again become a relatively expensive and exclusive food item. It has been stated that the average American today eats about 3 oysters each year, while New Yorkers in the 1800s ate about 600 oysters a year each (MacKenzie, 1996); while in 1864 in London, 700 million European flat oysters (Ostrea edulis) were consumed, and nearly 120,000 workers were employed in the various tasks involved in oyster dredging in Britain (Beck et al., 2011). We must all applaud the efforts of those who have developed, and continue to develop, farming operations for oysters and other shellfish to meet today's market demand for these nutritious primary foods. But this appreciation of oyster farming efforts does not go far enough; greater prizes are being won by this activity than merely meeting the economic market demand for a delicacy.

First, it is worth remembering that the oyster has been described as one of Nature's most perfect foods, and this applies to other filter-feeding shellfish, too. As well as being a good source of easily digested protein, oysters are low in cholesterol and fat, high in omega-3 fatty acids, and an excellent source of vitamins (A, B1, B2, B3, C, and D), and minerals (iron, magnesium, calcium, selenium, and zinc). A $100 \mathrm{~g}$ serving of uncooked oyster meat contains about 70 calories. Even oyster farming itself is climate friendly. Oyster farmers don't feed or add chemicals to their crop. Instead, they keep the oysters in an area where they can grow and be 
fed naturally. Far less energy input is required to produce an ounce of oyster protein than most other protein sources, from beans to beef (McMurray, 2018). But the benefits go much further even than this.

Second, it is well known that production of animal protein through livestock rearing by terrestrial farming is associated with high greenhouse gas (GHG) emissions, which have three main sources: anaerobic fermentation in the animal gut (most farm animals being ruminants), manure management, and fodder production. But oyster aquaculture is different (Ray et al. 2019). Oysters release no methane $\left(\mathrm{CH}_{4}\right)$ and only negligible amounts of nitrous oxide $\left(\mathrm{N}_{2} \mathrm{O}\right)$ and carbon dioxide $\left(\mathrm{CO}_{2}\right)$. Even the ocean sediment, which might be considered the equivalent of the livestock farmer's slurry, showed broadly unchanged fluxes of $\mathrm{N}_{2} \mathrm{O}$ and $\mathrm{CH}_{4}$ during oyster aquaculture.

“... There is no GHG-release from oyster fodder production. Considering the main drivers of GHG-release in terrestrial livestock systems, oyster aquaculture has less than $0.5 \%$ of the GHG-cost of beef, small ruminants, pork, and poultry in terms of CO2-equivalents per $\mathrm{kg}$ protein, suggesting that shellfish aquaculture may provide a low GHG alternative for future animal protein production compared to land based sources. We estimate that if $10 \%$ of the protein from beef consumption in the United States was replaced with protein from oysters, the GHG savings would be equivalent to 10.8 million fewer cars on the road ..." (Ray et al. 2019. the emphasis is ours).

Another estimate is that $\mathbf{8 5 \%}$ of the world's oyster beds have essentially disappeared (though in many bays more than $99 \%$ of oyster reefs have been lost), making those oyster beds the marine habitat that has been most severely impacted by human activities on the planet (Beck et al., 2011). Any response to the question 'what can be done now to restore exhausted fisheries?' must include establishment of regimes that protect and nurture all our invaluable marine resources, so that our generation uses them sustainably and leaves them in good order for all the generations that follow ours.

This ambition must be applied to all marine resources, not just shellfish, but here I concentrate on the native oyster reefs that once dominated so many estuaries, bays and coastlines. They dominated economically, of course, by providing for centuries of resource extraction, but this, worsened by coastal degradation is what pushed oyster reefs to the brink of functional extinction worldwide.

Oysters are unusual in that they create their own habitat; they have been described as ecosystem engineers, a status defined as the one or a few species that produce a reef habitat for entire ecosystems. Meaning that they create biogenic reef habitats of such significant size that they become important to general estuarine biodiversity. By providing habitats at different depths, they enhance benthic-pelagic coupling, and the result is overall improvement in fishery production (Lenihan \& Peterson, 1998; Beck et al., 2011).

On the other hand, it is a major loss to the entire ecosystems if the abundance and biomass of native oyster populations are decimated by the combined impacts of exploitation, disease, and habitat loss. In their survey of restored oyster reefs in the Neuse River estuary, North Carolina, USA, Lenihan \& Peterson (1998) found that a single season's oyster dredging reduced the height of restored oyster reefs by about $30 \%$. On deep experimental reefs they found that when the water column stratified in summer, oxygen depletion near the seafloor at $6 \mathrm{~m}$ depth caused mass mortality of oysters, other invertebrates, and fishes, though oysters and other organisms raised closer to the surface by sufficient reef height survived. Also, they found that the highly 
mobile blue crabs (Callinectes sapidus) abandoned burrows located in hypoxic/anoxic bottom waters in favour of those in shallow water.

Thus, to rebuild oyster populations it is essential to appreciate the dynamics of both the oyster population and the entire ecosystem the oysters engineer (Mann et al., 2009). It is the accumulated shells of past generations of shellfish that forms the foundation of the reef ecosystem and that's why we should recycle the oyster shells and put them back where they came from: "... If you have an oyster shell, the best thing to do is to put it back on the reef in order to start an ecological system. Once you've got the reef, then other fish come along and other flora and fauna can form around them. They purify the water and filter it, making it useful. But not everybody knows this ..." (Smith, 2015; the emphasis is ours).

Clover (2005) makes another point that not everybody knows, which is that, over in Europe, parts of the North Sea owe their modern-day turbidity to the removal of oyster beds that, more than a century ago, were producing 100 times more oysters than they do today. Maps made in the 19th century show oyster beds $200 \mathrm{~km}$ in length off the eastern shores of the North Sea (the continental Europe shore), the last of which were fished out before the Second World War. On this scale the filter-feeding oysters would have cleared the nutrients in suspension, clarifying the water of the day. Furthermore, such extensive bivalve reefs forming a hard substrate across so much of the seabed just offshore would have resulted in far less sediment being stirred up by wave action. If previous generations had been able to put into effect the conservation actions we know about today, present-day Europeans would not only have a much larger resource of oysters in the North Sea, but also clearer waters for swimmers and divers to enjoy.

Few of the research papers to which we have referred so far even mention this next point: specifically, that oyster shells are made from atmospheric $\mathrm{CO}_{2}$ which is permanently solidified in the form of crystalline calcium carbonate (as detailed in Section 2 above; Moore, 2021). In the US, oysters are usually sold by the bushel, which is a volume measure used for dry goods equal to 64 US pints (= 35.2 litre). One bushel of oysters contains between 100 and 150 oysters and weighs approximately 53 pounds $(=24 \mathrm{~kg})$ and yields approximately 7 pounds $(=3.2 \mathrm{~kg})$ of meat. So, a bushel of oysters contains about $20 \mathrm{~kg}$ of shell, which will remain intact for thousands, even hundreds of thousands of years if simply discarded.

Now, $20 \mathrm{~kg}$ of shell is equivalent to $2.4 \mathrm{~kg}$ of carbon captured, and permanently removed, from the atmosphere (see Section 2). FAO statistics (Helm, 2005) show total production of oyster farming of Crassostrea gigas (Pacific cupped oyster) over the 5 years 2010-2015 to be 3 million tonnes, so in those five years farming of this species alone removed 360,000 tonnes of carbon from the atmosphere. We already know (see above) that today's annual consumption of oysters is only about 1/200th of that reached at the end of the 19th century. If we could turn back the clock and restore oyster production to the level of oyster dredging in the year 1900, we could remove $\mathbf{1 4 , 4 0 0 , 0 0 0}$ tonnes of carbon from the atmosphere every year. Just with oyster cultivation.

Potentially, therefore, if we could expand present day oyster farms to a sufficient extent with animals collected from the wild to provide new recruits to existing self-sustaining oyster populations, we would achieve more than just restoration of an important part of the marine ecosystem. We would be making a serious contribution towards restoring the Earth's wider ecosystem by returning our atmosphere to its natural, pre-industrial, condition. It will not be easy. Most of the Pacific oysters (Crassostrea gigas) farmed today are of a triploid strain. Unfortunately, the market success of the strain is due to its partial reproductive sterility (Allen \& Downing, 1986). 
Natural (diploid) oysters tend to be unsavoury during the warm summer months of their spawning season, because their body consists mostly of gonads before spawning and is left thin and watery after spawning. The triploids are fat and marketable throughout the year because they produce so few eggs and sperm (Hollier, 2014).

Table 6. A few of the printed papers on aquaculture methods

\begin{tabular}{|c|c|}
\hline Citation & Title \\
\hline Ansa \& Bashir, 2007 & $\begin{array}{l}\text { Fishery and culture potentials of the mangrove oyster (Crassostrea } \\
\text { gasar) in Nigeria. URL: } \\
\text { http://www.medwelljournals.com/fulltext/rjbs/2007/392-394.pdf. }\end{array}$ \\
\hline Baker \& Baker, 2019 & $\begin{array}{l}\text { Carbon mineralization associated with aquaculture of the Northern } \\
\text { Quahog Mercenaria mercenaria. } \\
\text { https://doi.org/10.2983/035.038.0302. }\end{array}$ \\
\hline Bernal \& Oliva, 2016 & $\begin{array}{l}\text { Aquaculture. Chapter } 12 \text { in The First Global Integrated Marine } \\
\text { Assessment: World Ocean Assessment I, (Division for Ocean Affairs } \\
\text { and the Law of the Sea, Office of Legal Affairs, United Nations). DOI: } \\
\text { https://doi.org/10.1017/9781108186148.015. }\end{array}$ \\
\hline Costa-Pierce, 2002 & $\begin{array}{l}\text { Ecological Aquaculture: The Evolution of the Blue Revolution. DOI: } \\
\text { https://doi.org/10.1002/9780470995051. }\end{array}$ \\
\hline Cragg, 2016 & $\begin{array}{l}\text { Biology and Ecology of Scallop Larvae. Chapter } 2 \text { in: Scallops - } \\
\text { Biology, Ecology, Aquaculture, and Fisheries. DOI: } \\
\text { https://doi.org/10.1016/B978-0-444-62710-0.00002-X. }\end{array}$ \\
\hline Pogoda, 2019 & $\begin{array}{l}\text { Current status of European Oyster decline and restoration in } \\
\text { Germany. DOI: https://doi.org/10.3390/h8010009. }\end{array}$ \\
\hline Pogoda et al., 2019 & $\begin{array}{l}\text { The native oyster restoration alliance (NORA) and the Berlin Oyster } \\
\text { Recommendation: bringing back a key ecosystem engineer by } \\
\text { developing and supporting best practice in Europe. DOI: } \\
\text { https://doi.org/10.1051/alr/2019012. }\end{array}$ \\
\hline Sarkis \& Lovatelli, 2007 & $\begin{array}{l}\text { Installation and operation of a modular bivalve hatchery. FAO } \\
\text { Fisheries Technical Paper. No. 492. PDF download: } \\
\text { http://www.vliz.be/imisdocs/publications/ocrd/121106.pdf. }\end{array}$ \\
\hline Shumway \& Parsons, 2016 & $\begin{array}{l}\text { Scallops - Biology, Ecology, Aquaculture, and Fisheries. ISBN: } \\
9780444627100 .\end{array}$ \\
\hline Walne, 1979 & $\begin{array}{l}\text { Culture of bivalve molluscs: } 50 \text { years' experience at Conwy. ISBN: } \\
9780852380635 .\end{array}$ \\
\hline Wickins \& Lee, 2002 & $\begin{array}{l}\text { Crustacean Farming: Ranching and Culture. URL: } \\
\text { https://epdf.pub/crustacean-farming-ranching-and-culture.html. }\end{array}$ \\
\hline
\end{tabular}


Even when triploids can be made to breed successfully, the survival of fertilised eggs to metamorphosis and settlement was only about 0.0085\% (Guo \& Allen, 1994). Established farming methods could easily be applied to natural diploid oysters collected from the wild locally, with the aim of rearing them in farm-protected conditions through their first year before transfer to the locations of old (exhausted/extinct) oyster reefs with the specific aim of re-establishing those oyster beds to the scale that existed at the start of the 19th century. This is doable if we apply the same zeal to restoration as was applied to dredging operations during the 100-year abuse of the original oyster beds.

\section{Present day aquaculture}

Aquaculture should not be thought of solely in terms of "... a broader food landscape of wild aquatic and terrestrial food sources..." (Little et al., 2016) but in the even broader ecological context of the promise it holds for the restoration of the ecosystems we have used in the past to the level of quality that existed a few centuries ago when they first came to the attention as a food source to the civilisations such as the native Americans, the Romans, and then the great cities of the world in the 1800s: London, Bristol, Liverpool, New York, New Orleans and San Francisco. We must also change the paradigm; from shellfish farming for food to shellfish farming for whole-planet ecosystem repair and restoration. Take the food represented by shellfish meat as a by-product from the production of shell and leave or return the shell to the seabed from which it was harvested.

Shellfish farming has been a part of our history for over 100 years and the systems in use to farm shellfish have evolved from simple transfer of eggs or juveniles from their natural (inconvenient?) location to a more convenient location, to what are now technology-based systems that are designed for specific species and farming sites. There is an enormous amount of information available about aquaculture methods, both online and in print, a few of which are referenced in Table 6 (in addition to those referenced in this text). Google and Bing will find you any more you need, in an instant. The British Columbia Shellfish Growers' Association (BCSGA) website has a useful brief summary of the overall process at this URL: [https://seawestnews.com/], which we have used as a framework for this discussion. By definition, shellfish aquaculture is the farming (i.e., cultivation and harvest) of aquatic invertebrates, such as oysters, clams and mussels, but also the crustacea, crabs, lobsters, shrimp and prawns (some illustrated in the videos in Table 4). Cultivation implies involvement in the rearing process to enhance production, such as regular stocking and protection from predators. Most shellfish reproduce by releasing eggs and sperm into the water, generally in summer when the water is warm and planktonic food is abundant. After fertilisation of an egg, cell division produces swimming larvae that "... feed and feel an urgent need to grow more like their mothers ..." (Garstang, 1951).

The larvae eventually metamorphose into tiny bivalves, crabs or lobsters that settle to the seabed. This settling phase in oysters is the stage considered suitable for transplanting and may be called oyster spat or oyster seed. The farming cycle begins with the collection of larvae, which may be gathered in the wild or produced in farm hatcheries (depending on the species and location) (see Robert \& Gérard, 1999; Helm et al., 2004, for practical guides to bivalve hatcheries; and see Table 7 for hyperlinks to some videos).

- Clam larvae are kept in hatchery tanks where they transform into seed.

- Mussel larvae transform to juvenile animals.

- Scallop larvae settle and become juvenile animals.

- Oyster larvae are kept suspended in tanks by circulating water until they transform into seed. 


\begin{tabular}{|c|c|}
\hline Table 7. Aquaculture and foraging for other shellfish videos on YouTube & $\begin{array}{l}\text { CLICK to } \\
\text { launch }\end{array}$ \\
\hline $\begin{array}{l}\text { Clam farming: A forgotten industry in South Carolina, USA at } \\
\text { https://youtu.be/3FN8NVC4v1Y }\end{array}$ & $\underline{\text { CLICK }}$ \\
\hline $\begin{array}{l}\text { Coastal Foraging Wild Clams! Catch and Cook Homemade Clam Chowder in New } \\
\text { England at https://youtu.be/O9Kzd3RcvDg }\end{array}$ & $\underline{\text { CLICK }}$ \\
\hline $\begin{array}{l}\text { Onshore Abalone: The risks and rewards of onshore abalone farming in Australia } \\
\text { at https://youtu.be/Pwmb8u6Z44g }\end{array}$ & $\underline{\text { CLICK }}$ \\
\hline Abalone Farm in California at https://youtu.be/uDYbKOzUvFE & CLICK \\
\hline $\begin{array}{l}\text { Crawfish Agriculture in the Southern Regional Aquaculture Center with details of the } \\
\text { crawfish farming methods presently used in Louisiana and Southern Texas at } \\
\text { https://youtu.be/WAufhGUvCjA }\end{array}$ & $\underline{\text { CLICK }}$ \\
\hline Noal Farm Lobster Farming and processing at https://youtu.be/gaX8brdZT3k & CLICK \\
\hline Studying lobsters and crabs on Canada's east coast at https://youtu.be/li_61ldtL4o & CLICK \\
\hline $\begin{array}{l}\text { Feeding ground for rock lobsters on South Africa's western coast at } \\
\text { https://youtu.be/QhLqN2olDaA }\end{array}$ & $\underline{\text { CLICK }}$ \\
\hline $\begin{array}{l}\text { The National Lobster Hatchery, Padstow (Cornwall, England). Filmed by Manchester } \\
\text { Museum at https://youtu.be/Z6rbwuLmMw8 }\end{array}$ & CLICK \\
\hline
\end{tabular}

Farmers acquire clam and oyster seed at various stages of its development, depending on the requirements of their operation. The seed is put into a nursery environment where it is nurtured into juvenile animals. Generally speaking, the juvenile animals then graduate to the grow out phase of their development during which they mature to marketable size.

- Clams are spread on subtidal locations, which are the licenced aquaculture farms (called tenures in British Columbia), where they burrow and mature to marketable size over a period of two to four years.

- Mussels are relocated to deep water tenures where they are suspended in mesh socks to mature to marketable size over a period of 18 to 36 months.

- $\quad$ Scallops are transferred to deep water tenures where they are suspended in a mesh bag or tray (suspension culture) or are seeded on the ocean floor (bottom culture). Maturation to marketable size takes six to 36 months in suspension culture and an additional 24 to 36 months for bottom culture. Scallops are examples of the very few bivalves that do not attach to the sea floor. They are 'free-living' in the sense that many species are capable of swimming rapidly over short distances and even of migrating greater distances across the ocean floor.

- $\quad$ Oysters are frequently moved to a floating upwelling system called a flupsy (view the Long Island Shellfish Restoration Project YouTube video in Table 8). Ocean water is circulated through the flupsy and juvenile animals, kept in trays, are able to grow to a larger size. When they are large enough, the young oysters are moved to be reared in a growout 
system. The most common grow out techniques are raft, longline and intertidal (edited text from http://bcsga.ca/shellfish-farming-101/shellfish-aquaculture/).

\begin{tabular}{|c|c|}
\hline Table 8. Oyster aquaculture videos on YouTube & $\begin{array}{l}\text { CLICK to } \\
\text { launch }\end{array}$ \\
\hline $\begin{array}{l}\text { Explanation of the flupsy (used to grow oysters) by the Long Island Shellfish } \\
\text { Restoration Project at https://youtu.be/FjSNOIJCG8s }\end{array}$ & $\underline{\text { CLICK }}$ \\
\hline $\begin{array}{l}\text { FlipFarm is an innovative oyster growing system designed and operated by } \\
\text { Marlborough Oysters Ltd in New Zealand. FlipFarm provides an ideal environment for } \\
\text { oyster growth, conditioning and hardening along with the ability to have complete control } \\
\text { over fouling, pests and predators [https://youtu.be/CGe3wSV3B8w] }\end{array}$ & $\underline{\text { CLICK }}$ \\
\hline $\begin{array}{l}\text { Video showing the sea conditions at some FlipFarm sites. The baskets ride this out and } \\
\text { oysters are rumbling so this site is good for finishing stock ready for harvest } \\
\text { [https://youtu.be/RbXH2OP-ADk] }\end{array}$ & $\underline{\text { CLICK }}$ \\
\hline FlipFarm harvesting intermediate oysters for sale at https://youtu.be/ye-a-vAaL5k & $\underline{\text { CLICK }}$ \\
\hline $\begin{array}{l}\text { The latest addition to the FlipFarm gear is a helix flipper, used to rotate the baskets into } \\
\text { the drying position, which kills biofouling, creates more even and better shaped shell } \\
\text { growth, hardens oysters and improves meat condition [https://youtu.be/ZX54JdEccXc] }\end{array}$ & $\underline{\text { CLICK }}$ \\
\hline $\begin{array}{l}\text { OysterGro® Aquafarming Systems (Bouctouche Bay, Saint-Édouard-de-Kent, New } \\
\text { Brunswick, Canada) at https://youtu.be/e33ZII2DMN4 }\end{array}$ & $\underline{\text { CLICK }}$ \\
\hline $\begin{array}{l}\text { Oyster farming and harvesting in Japan - Big Oyster Cultivation at } \\
\text { https://youtu.be/cdKBZpOMDfk }\end{array}$ & $\underline{\text { CLICK }}$ \\
\hline $\begin{array}{l}\text { Oyster Farming in the Southern United States Using the OysterGro System funded } \\
\text { by the USDA at https://youtu.be/SOOpUeovaLQ }\end{array}$ & $\underline{\text { CLICK }}$ \\
\hline $\begin{array}{l}\text { Gregg Morris owner of } 2 \text { Rock Oyster Farm (Duxbury, MA, US) shows how oyster } \\
\text { farming is done in Duxbury Bay at https://youtu.be//bbSRv8QDyTc }\end{array}$ & $\underline{\text { CLICK }}$ \\
\hline $\begin{array}{l}\text { Farming the Sea; aquaculture in Florida. A full } 26 \text { min episode from Changing Seas TV } \\
\text { [https://www.changingseas.tv/] at https://youtu.be/EAN-VRvD8_k }\end{array}$ & $\underline{\text { CLICK }}$ \\
\hline $\begin{array}{l}\text { Oyster Farming at Tio Point (District of Marlborough on the South Island of New } \\
\text { Zealand) at https://youtu.be/m5VdJ0Ed03c }\end{array}$ & $\underline{\text { CLICK }}$ \\
\hline
\end{tabular}

\section{Introducing Giant Clams}

So far, Northern Hemisphere shellfish cultivation has dominated this review, but now we want to briefly discuss a dramatic example from the tropics. And there is nothing more dramatic than Giant Clams, which have been fished out to extinction in many Pacific and Indian Ocean waters, a practice which has done immense damage to coral reefs in many areas. Several replenishment efforts have made successful contributions both to a still thriving clam fishing industry and to coral reef conservation and restoration in general. 

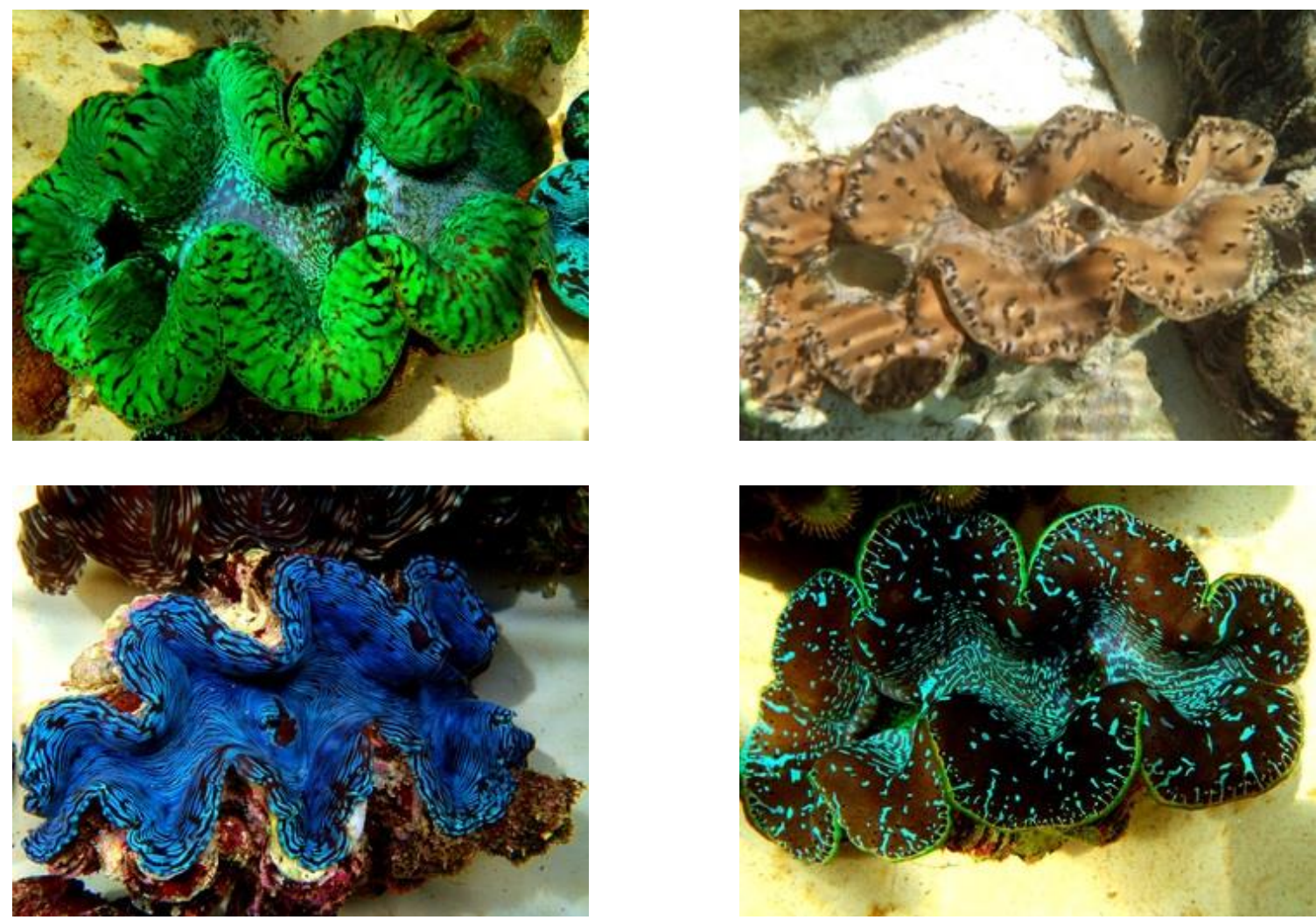

Fig. 9. Brightly coloured giant clams wanted by the aquarium industry as living decoration in home and public marine aquaria. Image from The Tridacna Mariculture Development Center website [http://lagoonclams.com/].

There are a number of large clam species which are native to the shallow coral reefs of the South Pacific and Indian oceans, the South China Sea, and the shores of the Philippines and Borneo. They have a long history of traditional and cultural use in the region and their European documentation goes back to 1521 when the chronicler of Ferdinand Magellan's circumnavigation, the Venetian scholar Antonio Pigafetta, documented Giant Clams in his journal.

Giant Clams have always been, and remain, an important resource throughout the tropical IndoPacific region, from Mauritius to the South China Sea. Traditionally, the meat of the animals has been an important subsistence food and the shell has been used to make dishes, tools, jewellery and ornaments (Ellis, 1997; Morris et al. 2019).

Markets for these animals have changed a great deal more recently but they are still heavily harvested. The meat is widely sold in Asian and Pacific markets as a delicacy, rather than a staple food, so it maintains a premium price level. Chinese Traditional Medicine believes that the clam's adductor muscle has aphrodisiac powers. The most recent use for the more brightly coloured species of giant clam is as a living decoration in home and public marine aquaria (Fig. 9).

\section{Biology and natural history of Giant Clams}

Giant clams (Phylum Mollusca: Class Bivalvia: Family Tridacnidae) are the largest marine bivalve molluscs of the present day. They are found in coastal areas of the Indo-Pacific region; 
ranging eastwards from Cape Agulhas, the southern tip of the African continent and the dividing line between the Atlantic and Indian Oceans (Syukri bin Othman et al., 2010). In the present day, eight species of giant clam of varying size and habitat preference have been described (Tridacna gigas, T. derasa, T. squamosa, T. maxima, T. crocea, T. tevora, Hippopus hippopus and $H$. porcellanus). A ninth species, Tridacna rosewateri has been described more recently and is endemic to Mauritius.

T. maxima and T. crocea are smaller but more colourful clams and are found within limestone substrata; free-living species ( $T$. squamosa, $T$. derasa and $T$. gigas) are larger and usually occur near reefs or on sandy sea bottoms. Similarly, Hippopus spp. are usually found in seagrass beds. All these bivalves are unusual in that their mantle tissues act as a habitat for symbiotic single-celled dinoflagellate algae (zooxanthellae; Symbiodinium spp.) from which the adult clams get most of their nutrition (although the clams are also filter-feeders). By day, the clam opens its shell and extends its mantle tissue so that the algae receive the sunlight they need to photosynthesise, the animal benefits from the products of photosynthesis. Giant clams are a highly prized food source, and both subsistence fishing and commercial fishing, which exports clam meat to many Asian markets, have been responsible for stock depletion across their range. The clams are also harvested for their shells and for live export for the marine aquarium trade (Teitelbaum \& Friedman, 2008).

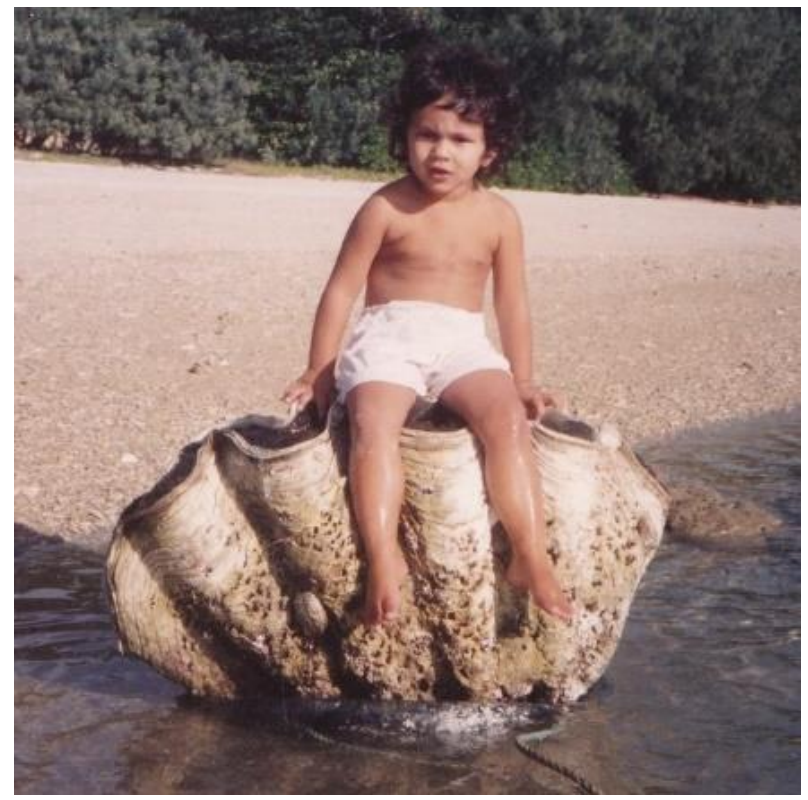

Fig. 10. Tridacna gigas, as its specific name indicates, is the species which truly merits the description 'Giant'. Here, a young islander, is determined not to allow his find to escape from Fizroy Island, Australia. Image from The Tridacna Mariculture Development Center website [http://lagoonclams.com/].

Tridacna gigas, as its specific name indicates, is the species which truly merits the description 'Giant'; these are very large animals (Fig. 10). According to the website of the Mongabay Conservation and Environmental Science News Service, the world's biggest specimen of Tridacna gigas was found off the coast of Sumatra. This specimen measured $1.4 \mathrm{~m}$ across and 
its two shells weighed a total of $230 \mathrm{~kg}$, which is said to be rather more than an average female grizzly bear [https://news. mongabay.com/] but represents a fair chunk of atmospheric carbon.

The other species are smaller than $T$. gigas, but still large enough to be called giants. With their large size and impressive mantle colours, ranging from electric blue, through green, pink, and purple to gold, giant clams have been described as "charismatic megafauna" that act as flagship taxa, which, unfortunately, serve to direct attention to the continuing destruction of coral reefs (Soo \& Todd, 2014).

It is likely that clam harvesting by subsistence fishing was sustainable for centuries until commercial fishers took the animals from the waters to satisfy an increasing demand for them as food and for jewellery crafts, but also for the aquarium trade and traditional medicine. So, by the end of the twentieth century, many giant clam species had become overharvested and were even locally extinct in some regions. The increased giant clam trade and poaching have resulted in widespread coral reef destruction in the South China Sea, as poachers use boat propellers to loosen the giant clams from the reef (for references to these assertions, see FriasTorres, 2017).

Today, four of the giant clam species are listed as Vulnerable by the IUCN Red List (view: https://www.iucnredlist.org/), including Tridacna gigas, while others are listed as Lower Risk or Conservation Dependent with commercial trade regulated by the Convention on International Trade in Endangered Species of Wild Fauna and Flora, see Appendix II (CITES, 2013). Hippopus hippopus is also in severe danger because it is often harvested for its decorative shell as well as for its meat (Wells, 1996).

Conservationists have responded to this decline in the giant clam populations with research and conservation efforts. Over the past 40 years or so, scientists from all over the IndoPacific region have closely studied giant clam biology and cultivation methods to support programmes for giant clam restocking, conservation, farming, public education, and, because giant clams live in close association with coral reefs throughout the Indo-Pacific, the management and conservation of coral reefs. Climate change is the new threat, as it is elsewhere, and could have long-term impacts on the giant clam family.

\section{Giant clams and coral reefs}

There has been only limited success for programmes aimed at restocking giant clams by replacing clams in fished-out coastal environments. Projects have been carried out in Australia, Philippines and the Pacific Islands (Palau, Solomon Islands, Vanuatu, Tonga, Marshall Islands and Cook Islands). Teitelbaum \& Friedman (2008) conclude that most restocking projects have been only partially successful. The reasons for these mixed results include the following.

- The high costs and lengths of time required to produce "seed" clams have been problems for many operations. High mortality of juvenile clams has also reduced success rates.

- In the initial stages, lack of knowledge about rearing and growing clams was a problem for many of the participating countries.

- Lack of consistently committed involvement of local communities in the projects. In some cases, projects were not matched to what the local community needed or wanted.

- Poor survey and reporting protocols, together with poor funding for monitoring, have limited assessment of some reintroduction and restocking programmes even to the point of failing to report successful results. 
Coral reef bleaching, resulting from increasing water temperatures and water acidity (both generated by the anthropogenic increase in atmospheric carbon dioxide) is the reef ailment that is most reported in the public media. But these seawater changes have also been demonstrated to have adverse effects on at least two species of giant clams, Tridacna squamosa and $T$. crocea in Thailand (Junchompoo et al., 2013). Exposure to temperatures over $30^{\circ} \mathrm{C}$ for longer than two weeks could result in the expulsion of the symbiotic living zooxanthellae from the mantles. As these dinoflagellates make such a significant contribution to the nutrition of their host, their loss must have a direct impact on survival of the giant clam.

There are several examples of the use of mariculture linked to restoration (re-stocking) of reefs being attempted as a solution to reverse giant clam extinctions locally. Despite some early failures, it was concluded nearly 40 years ago that "... no serious biotechnical constraints would prevent commercial or subsistence farming of these autotrophic animals in the Indo-West Pacific ..." (Heslinga et al., 1984).

More recently, Schmidt-Roach et al. (2020) have reviewed proposals to restore coral reef populations and point out that the scale of the work required to implement these concepts in habitats on an ecosystem-wide management remains a major limitation for logistical and, more importantly, financial reasons. Their solution is to suggest implementation by including landbased coral gardening into architectural elements to enhance and beautify coastal development sites.

The review paper entitled Rebuilding marine life (Duarte et al., 2020), concludes that achieving the United Nations Sustainable Development Goal 14 (to "... conserve and sustainably use the oceans, seas and marine resources for sustainable development ..." [https://www.un.org/]) “... will require rebuilding the marine life-support systems that deliver the many benefits that society receives from a healthy ocean ...". But they finally conclude that "... Rebuilding marine life represents a doable Grand Challenge for humanity, an ethical obligation and a smart economic objective to achieve a sustainable future ...". In the opinion of Duarte et al. (2020), recovery rates seen in past studies of conservation interventions suggest that "... substantial recovery of the abundance, structure and function of marine life could be achieved by 2050, if major pressures - including climate change - are mitigated ...".

The political limitations of conventional ecosystem governance are discussed by Morrison et al. (2020), focussing on coral reefs and the need to reassess the long-standing assumptions about coping with climate change caused by human activity, particularly the assumption that strong local institutions can maintain ecological and social resilience through management of the ecosystem adaptation and restoration. They conclude that a new governance paradigm applicable to all ecosystems is required. Governance that serves local needs for conservation and traditional livelihoods is not sufficient; it must be changed to encompass the interests of a broader range of stakeholders, investors and sponsors. As examples they cite governance of the Great Barrier Reef and governance of the Pacific Islands.

In their letter to the journal Science, Gordon et al.(2020) claim that "... Marine restoration projects are undervalued ...". In their final paragraph they conclude that "... Political agreements for global reductions in atmospheric carbon have been slow to emerge. Relying on their implementation as the only solution to the degradation of tropical habitats is a major gamble. In the meantime, restoration projects could help maintain species survival and ecosystem services, ultimately providing humanity with the breathing space to stabilize the climate ..." (Gordon et al., 2020). 
Overall, then, there is no shortage of scientific and practical knowhow about what could be done to rescue our suffering coral reef ecosystems. But there is insufficient effort due to poor financial, legislative and political support to make sure that what could be done is put into effect over the necessary time and geographic scales.

For 40 years or more a wide range of academics and agencies have studied the decline of stocks of giant clams and their coral reef habitats due to commercial over-fishing, climate change and growth in demand for aquarium supplies and recreational (tourist) SCUBA fishing. It is evident that (a) numerous well tested techniques and protocols exist that are able, within a reasonable time scale, to restore the biodiversity of coral reef systems to something close to normality; and (b) local efforts to implement these conservation schemes are in general only partially successful for a mixture of reasons, among which are limited time and limited funding both contributing to limited scale of the operations. But the greatest limitations emerge from conflicting demands between conservationists and local communities and conflicting politics between local, regional and even national and international administrations. Evidently the concern which has been expressed over the governance (Morrison et al., 2020) and undervaluation (Gordon et al. 2020) of marine restoration projects is fully justified.

The fundamental problem is that though many people bemoan the sad fact that giant clams (and the coral reefs to which so many of them contribute) are on an accelerating march towards extinction, there are too few people doing anything in practical terms on a sufficiently large scale to reverse their march to extinction. Like many other conservation issues, some well-funded central authority needs to take it by the scruff of the neck, shake it free of self-serving contradictions and drive it into effective action on a world-wide basis.

All of these animals, mussels, oysters, clams of all sizes, and corals too, deserve in the 21 st century, to have the same vigour applied to their restoration and conservation as we apply to dredging them from the seabed. And in return they will cleanse our atmosphere by permanently sequestering its excess $\mathrm{CO}_{2}$ into limestone. And we must start now, before Homo sapiens is added to the list of organisms driven to extinction by humanity's follies.

\section{References}

Allen S.K. \& Downing S.L. 1986. Performance of triploid Pacific oysters, Crassostrea gigas (Thunberg). I. Survival, growth, glycogen content, and sexual maturation in yearlings. Journal of Experimental Marine Biology and Ecology. 102: 197-208. DOI: https://doi.org/10.1016/00220981(86)90176-0.

Avdelas L., Avdic-Mravlje E., Borges Marques A.C., Cano S., Capelle J.J. and 17 others. 2020. The decline of mussel aquaculture in the European Union: causes, economic impacts and opportunities. Reviews in Aquaculture. in press, online before inclusion in an issue. DOI: https://doi.org/10.1111/raq.12465.

Bae C.J., Douka K. \& Petraglia M.D. 2017. On the origin of modern humans: Asian perspectives. Science. 358: article eaai9067. DOI: https://doi.org/10.1126/science.aai9067.

Bale R. (2017). This turtle tourist center also raises endangered turtles for meat. National Geographic Magazine. 25 May 2017. URL: https://www. nationalgeographic.com/. 
Bardach J.E., Ryther J.H. \& McLarney W.O. 1972. Aquaculture - the farming and husbandry of freshwater and marine organisms. New Jersey, USA: John Wiley \& Sons, Inc. 351 pp. ISBN 13: 9780471048268.

Beck M.W., Brumbaugh R.D., Airoldi L., Carranza A., Coen L.D., Crawford C., Defeo O., Edgar G.J., Hancock B., Kay M.C., Lenihan H.S., Luckenbach M.W., Toropova C.L., Zhang G. \& Guo $X$. 2011. Oyster reefs at risk and recommendations for conservation, restoration, and management. BioScience. 61: 107-116. DOI: https://doi.org/10.1525/bio.2011.61.2.5.

Berg D.E., Kohn M.A., Farley T.A. \& McFarland L.M. 2000. Multi-state outbreaks of acute gastroenteritis traced to fecal-contaminated oysters harvested in Louisiana. The Journal of Infectious Diseases. 181, Issue Supplement 2: S381-S386. DOI: https://doi.org/10.1086/315581.

Bernal P. \& Oliva D. 2016. Aquaculture. Chapter 12 in The First Global Integrated Marine Assessment: World Ocean Assessment I, (eds L. Inniss, A. Simcock et al. for the Division for Ocean Affairs and the Law of the Sea, Office of Legal Affairs, United Nations). Pp. 203-212. Cambridge, UK: Cambridge University Press. DOI: https://doi.org/10.1017/9781108186148.015.

Beveridge M.C.M. \& Little D.C. 2002. The history of aquaculture in traditional societies. Chapter 1, pp. 1-29 in: Ecological Aquaculture. The Evolution of the Blue Revolution, (ed B.A. CostaPierce). Oxford: Blackwells. 382 pp. ISBN: 9780632049615. DOI: https://doi.org/10.1002/9780470995051. Chapter DOI: https://doi.org/10.1002/9780470995051.ch1. Open access URL: https://www.researchgate.net/.

Bindoff N.L., Cheung W.W.L., Kairo J.G., Arístegui J., Guinder V.A., Hallberg R., et al. 2019. Changing Ocean, Marine Ecosystems, and Dependent Communities. Chapter 5 (pp. 447-588) in: IPCC, 2019: IPCC Special Report on the Ocean and Cryosphere in a Changing Climate, (eds H.-O. Pörtner, D.C. Roberts, V. Masson-Delmotte, P. Zhai, M. Tignor, E. Poloczanska, K. Mintenbeck, A. Alegría, M. Nicolai, A. Okem, J. Petzold, B. Rama \& N.M. Weyer). Geneva: Intergovernmental Panel on Climate Change. Open access. URL Chapter 5 (142 pp.): https://www.ipcc.ch/srocc/chapter/chapter-5/. URL Full Report (765 pp.): https://www.ipcc.ch/.

Boey P-L.L., Maniam G.P., Hamid S.A. \& Ali D.M.H. 2011. Utilization of waste cockle shell (Anadara granosa) in biodiesel production from palm olein: optimization using response surface methodology. Fuel. 90: 2353-2358. DOI: https://doi.org/10.1016/..fuel.2011.03.002.

Briggs M., Funge-Smith S., Subasinghe R.P. \& Phillips M. 2005. Introductions and movement of two penaeid shrimp species in Asia and the Pacific. FAO Fisheries Technical Paper 476. Rome: .Food and Agriculture Organization of the United Nations. ISBN: 9251053626 URL: http://www.fao.org/3/a0086e/a0086e00.htm.

Chambers R.A. \& Gray M. 1988. The excavation of fishponds. In: Medieval Fish, Fisheries and Fishponds in England, (ed M. Aston). Pp. 113-128. Oxford, UK: BAR Publishing (British Archaeological Reports Publishing) British Series, Volume 182. 484 pp. ISBN: 9780860545095. URL: https://www.barpublishing.com/mediaeval-fish-fisheries-and-fish-ponds-in-england.html.

CITES, 2013. Convention on International Trade in Endangered Species of Wild Fauna and Flora (2013). Appendices I, II and III. URL: https://cites.org/eng/app/appendices.php. [Free PDF download: https://cites.org/sites/default/files/eng/app/2020/E-Appendices-2020-08-28.pdf]. 
Clark D. 2009. The Rough Guide to Green Living. London: Rough Guides® (Apa Digital AG, Switzerland). Pp. 336. ISBN: 9781848361072.

Clover C. 2005. The End of the Line: How Overfishing Is Changing the World and What We Eat. London: Ebury Press, the non-fiction imprint of Penguin Random House. 320 pp. ISBN: 9780091897819.

Cole H. 1942. The American whelk tingle, Urosalpinx cinerea (Say), on British oyster beds. Journal of the Marine Biological Association of the United Kingdom. 25: 477-508. DOI: https://doi.org/10.1017/S0025315400055119.

Connor S.A. 2008. Can seashells save the world? Science News in: The Independent, of Wednesday 23 April 2008. URL: https://www.independent.co.uk/news/science/can-seashellssave-the-world-813915.html.

Currie C.K. 1991. The early history of the carp and its economic significance in England. Agricultural History Review. 11: 97-107. URL: https://www.bahs.org.uk/AGHR/ARTICLES/39n2a1.pdf.

De Silva S.S., Zhitang Y. \& Lin-Hu X. 1991. A brief review of the status and practices of the reservoir fishery in mainland China. Aquaculture Research. 22: 73-84. DOI: https://doi.org/10.1111/j.1365-2109.1991.tb00496.x.

Duarte C.M., Agusti S., Barbier E., Britten G.L., Castilla J.C., Gattuso J.P., Fulweiler R.W., Hughes T.P., Knowlton N., Lovelock C.E., Lotze H.K., Predragovic M., Poloczanska E., Roberts C. \& Worm B. 2020. Rebuilding marine life. Nature. 580, 39-51. DOI: https://doi.org/10.1038/s41586-020-2146-7.

Earll R. 2018. Marine Conservation: People, Ideas and Action. Exeter, UK: Pelagic Publishing. 303 pp. ISBN: 9781784271763.

Ellis S. 1997. Spawning and early larval rearing of giant clams (Bivalvia: Tridacnidae). Open Source Publication Number 130. Center for Tropical and Subtropical Aquaculture: Waimanalo, Hawai'i 96795, USA.

URL: http://www.ctsa.org/files/publications/CTSA 1306316728608730954041.pdf.

Ellison A.M. 2019. Foundation species, non-trophic interactions, and the value of being common. iScience. 13: 254-268. DOI: https://doi.org/10.1016/i.isci.2019.02.020.

Erlandson J.M. 2001. The archaeology of aquatic adaptations: paradigms for a new millennium. Journal of Archaeological Research. 9: 287-350. DOI: https://doi.org/10.1023/A:1013062712695.

FAO, 1983. Freshwater aquaculture development in China. Report of the FAO/UNDP study tour organized for French-speaking African countries. 22 April-20 May 1980. FAO Fisheries Technical Paper 215. 125 pp. Rome: Food and Agriculture Organization of the United Nations. ISBN: 9251011133. URL: http://www.fao.org/3/AD016E/AD016E00.htm\#TOC.

FAO, 2014. The State of World Fisheries and Aquaculture 2014. Opportunities and challenges. Rome:FAO. URL: http://www.fao.org/3/a-i3720e.pdf. 
FAO, 2016. Species Fact Sheets: Procambarus clarkii (Girard, 1852). FAO Fisheries Division. URL: http://www.fao.org/fishery/species/3454/en.

FAO, 2017. Fishery and Aquaculture Country Profiles: The People's Republic of China (2017). Country Profile Fact Sheets. In: FAO Fisheries Division [online]. Rome: FAO. URL: http://www.fao.org/fishery/facp/chn/en.

FAO, 2019. Fishery and Aquaculture Country Profiles: The United States of America (2019). Country Profile Fact Sheets. In: FAO Fisheries Division [online]. Rome: FAO. URL: http://www.fao.org/fishery/facp/USA/en.

FAO, 2020a. Species Fact Sheets: Macrobrachium rosenbergii (De Man, 1879). FAO Fisheries Division. URL: http://www.fao.org/fishery/species/2608/en.

FAO, 2020b. The State of World Fisheries and Aquaculture 2020. Sustainability in action. Rome:FAO. URL: https://doi.org/10.4060/ca9229en.

Filgueira R., Strohmeier T. \& Strand $\varnothing$. 2019. Regulating services of bivalve molluscs in the context of the carbon cycle and implications for ecosystem valuation. In: Goods and Services of Marine Bivalves (ed Smaal A., Ferreira J., Grant J., Petersen J. \& Strand Ø.), pp. 231-251. Springer Nature. Cham, Switzerland. Open access download: https://link.springer.com/content/pdf/10.1007\%2F978-3-319-96776-9 12.pdf.

Foodworthwritingfor.com 2018. The history of oysters: its rise as a delicacy and a staple food beloved by many. Foodworthwritingfor blog. Written by C.P. July 31, 2018. URL: https://foodworthwritingfor.com/2018/07/31/the-history-of-oysters-its-rise-as-a-delicacy-and-astaple-food-beloved-by-many.

Franz D.R. 1993. Allometry of shell and body weight in relation to shore level in the intertidal bivalve Geukensia demissa (Bivalvia: Mytilidae). Journal of Experimental Marine Biology and Ecology. 174: 193-207. DOI: https://doi.org/10.1016/0022-0981(93)90017-I.

Frias-Torres S. 2017. Captive bred, adult Giant Clams survive restoration in the wild in Seychelles, Indian Ocean. Frontiers in Marine Science. 4: article 97. DOI: https://doi.org/10.3389/fmars.2017.00097.

Garstang W. 1951. Larval Forms, and Other Zoological Verses. Oxford: Basil Blackwell. 85 pp. ISBN: 9780631070900. URL: http://www.booktryst.com/2012/09/poetry-in-larvae-love-songs-ofwalter.html.

Gimin R., Mohan R., Thinh L.V. \& Griffiths A.D. 2004. The relationship of shell dimensions and shell volume to live weight and soft tissue weight in the mangrove clam, Polymesoda erosa (Solander, 1786) from northern Australia. NAGA, WorldFish Center Quarterly. 27: Nos. 3 \& 4, Jul-Dec 2004. URL: http://www.worldfishcenter.org/Naga/na 2318.pdf.

Gonzalez-Poblete E., Hurtado F. C.F., Rojo S. C. \& Norambuena C. 2018. Blue mussel aquaculture in Chile: small or large scale industry? Aquaculture. 493: 113-122. DOI: https://doi.org/10.1016/i.aquaculture.2018.04.026.

Gordon T.A.C., Radford A.N., Simpson S.D. \& Meekan M.G. 2020. Marine restoration projects are undervalued. Science. 367: 635-636. DOI: https://doi.org/10.1126/science.aba9141. 
Groesbeck A.S., Rowell K., Lepofsky D. \& Salomon A.K. 2014. Ancient clam gardens increased shellfish production: adaptive strategies from the past can inform food security today. PLoS ONE. 9: article e91235. DOI: https://doi.org/10.1371/journal.pone.0091235.

Guo X. \& Allen S.K. 1994. Reproductive potential and genetics of triploid Pacific oysters, Crassostrea gigas (Thunberg). Biological Bulletin. 187: 309-318. DOI: https://doi.org/10.2307/1542288.

Hamed I., Özogul F. \& Regenstein J.M. 2016. Industrial applications of crustacean by-products (chitin, chitosan, and chitooligosaccharides): A review. Trends in Food Science \& Technology. 48: 40-50. DOI: https://doi.org/10.1016/i.tifs.2015.11.007.

Haitao S., Parham J.F., Lau M. \& Tien-Hsi C. 2007. Farming endangered turtles to extinction in China. Conservation Biology. 21: 5-6. DOI: https://doi.org/10.1111/i.1523-1739.2006.00622 2.x.

Hausmann N., Meredith-Williams M. \& Laurie E. 2020. Shellfish resilience to prehistoric human consumption in the southern Red Sea: variability in Conomurex fasciatus across time and space. Quaternary International. in press, online ahead of publication. DOI: https://doi.org/10.1016/i.quaint.2020.04.034.

Heilweck M. \& Moore D. 2021. Saving the Planet with Appropriate Biotechnology: 3. The High Seas Solution/Salvando el planeta con biotecnología apropiada: 3. La solución de alta mar. Mexican Journal of Biotechnology. 6(1): 92-128. DOI:

https://doi.org/10.29267/mxjb.2021.6.1.92.

Helm M.M. 2005. Cultured Aquatic Species Information Programme: Crassostrea gigas. In: FAO Fisheries Division [online]. Rome: Food and Agriculture Organization of the United Nations. URL: http://www.fao.org/fishery/culturedspecies/Crassostrea gigas/en.

Helm M.M., Bourne N. \& Lovatelli A. 2004. Hatchery Culture of Bivalves. A Practical Manual. FAO Fisheries Technical Paper. No. 471, pp. 203. Rome: Food and Agriculture Organization of the United Nations. ISBN 9251052247. URL: http://www.fao.org/3/y5720e/y5720e02.htm. PDF: http://aquacultura.org/.

Henshilwood C., d'Errico F., Vanhaeren M., van Niekerk K. \& Jacobs Z. 2004. Middle Stone Age shell beads from South Africa. Science. 304: 404. DOI: https://doi.org/10.1126/science.1095905.

Heslinga G., Perron F.E. \& Orak O. 1984. Mass culture of giant clams (F. Tridacnidae) in Palau. Aquaculture. 39: 197-215. DOI: https://doi.org/10.1016/0044-8486(84)90266-7.

Hilborn R. \& Hilborn U. 2012. Overfishing: What Everyone Needs to Know. New York, USA: Oxford University Press Inc. 168 pp. ISBN: 9780199798148.

Hoffman R.C. 1996. Economic development and aquatic ecosystems in Medieval Europe. American Historical Review. 101: 631-669. DOI: https://doi.org/10.1086/ahr/101.3.631.

Hollier D. 2014. Tasty mutants: the invention of the modern oyster. Posting on The Atlantic magazine's website [https://www.theatlantic.com/world/]. Article URL: https://www.theatlantic.com/. 
Hu S., Wang Y. \& Han H. 2011. Utilization of waste freshwater mussel shell as an economic catalyst for biodiesel production. Biomass and Bioenergy. 35: 3627-3635. DOI: https://doi.org/10.1016/..biombioe.2011.05.009.

Jackley J., Gardner L., Djunaedi A.F. \& Salomon A.K. 2016. Ancient clam gardens, traditional management portfolios, and the resilience of coupled human-ocean systems. Ecology and Society. 21: article 20. DOI: https://doi.org/10.5751/ES-08747-210420.

Jones T.L. \& Richman J.R. 1995. On mussels: Mytilus californianus as a prehistoric resource. North American Archaeologist. 16: 33-58. DOI: https://doi.org/10.2190/G5TT-YFHP-JE6AP2TX.

Jović M., Mandić M., Šljivić-Ivanović M. \& Smičiklas I. 2019. Recent trends in application of shell waste from mariculture. Studia Marina, 32: 47-62. DOI: http://doi.org/10.5281/zenodo.3274471.

Junchompoo C., Sinrapasan N., Penpian C. \& Patsorn P. 2013. Changing seawater temperature effects on giant clams bleaching, Mannai Island, Rayong province, Thailand. In: Proceedings of the Design Symposium on Conservation of Ecosystems (the 12th SEASTAR2000 workshop). Kyoto University, Japan (2013): 71-76. DOI: https://doi.org/10.14989/176186.

Kungvankij P. 1984. Overview of penaeid shrimp culture in Asia. Paper presented at the First International Conference on Shrimp and Prawn Culture in December 1984, at the SEAFDEC Aquaculture Department, Iloilo, Philippines. NACA/WP/84/11. URL: http://www.fao.org/3/ac242e/ac242e00.htm.

Leather J. 1991. Smacks and Bawleys. Sudbury, Suffolk, UK: Terence Dalton Ltd. 160 pp. ISBN: 9780861380794.

Lenihan H.S. \& Peterson C.H. 1998. How habitat degradation through fishery disturbance enhances impacts of hypoxia on oyster reefs. Ecological Applications. 8: 128-140. DOI: https://doi.org/10.1890/1051-0761(1998)008[0128:HHDTFD12.0.CO;2.

Lepofsky D., Toniello G., Earnshaw J., Roberts C., Wilson L., Rowell K. \& Holmes K. 2020. Ancient anthropogenic clam gardens of the northwest coast expand clam habitat. Ecosystems. 2020. DOI: https://doi.org/10.1007/s10021-020-00515-6.

Li F., Wu N., Lu H., Zhang J., Wang W., Ma M., Zhang X. \& Yang X. 2013. Mid-Neolithic exploitation of mollusks in the Guanzhong Basin of Northwestern China: preliminary results. PLOS ONE. 8: article e58999. DOI: https://doi.org/10.1371/journal.pone.0058999.

Little D.C. \& Edwards P. 2003. Integrated livestock-fish farming systems. 125 pp. Rome: Food and Agriculture Organization of the United Nations. ISBN: 9251050554. PDF download: http://www.fao.org/3/a-y5098e.pdf.

Little D.C., Newton R.W. \& Beveridge M.C.M. 2016. Aquaculture: A rapidly growing and significant source of sustainable food? Status, transitions and potential. Proceedings of the Nutrition Society. 75: 274-286. DOI: https://doi.org/10.1017/S0029665116000665.

Liu Q. \& Chen L. 2002. Paddy culture: Chinese mitten-handed crabs. Global Aquaculture Advocate, December 2002. URL: https://www.aquaculturealliance.org/advocate/paddy-culturechinese-mitten-handed-crabs/. 
Lovatelli A. 1990. Artificial propagation of bivalves: techniques and methods. Technical paper prepared as part of the Mollusc-Shellfish Culture Course of the 7th NACA Training Course for Senior Aquaculturists in Asia and in the Pacific. FAO/UNDP Regional Seafarming Demonstration and Development Project (RAS/90/002) Bangkok, Thailand: National Inland Fisheries Institute, Kasetsart. URL: http://www.fao.org/3/AB739E/AB739E00.htm.

MacKenzie Jr. C.L. 1996. History of oystering in the United States and Canada, featuring the eight greatest oyster estuaries. Marine Fisheries Review. 58: 1-78. URL: http://aquaticcommons.org/9826/1/mfr5841.pdf.

Macreadie P.I., Anton A., Raven J.A., Beaumont N., Connolly R.M., Friess D.A., Kelleway J.J., Kennedy H., Kuwae T., Lavery P.S., Lovelock C.E., Smale D.A., Apostolaki E.T., Atwood T.B., Baldock J., Bianchi T.S., Chmura G.L., Eyre B.D., Fourqurean J.W., Hall-Spencer J.M., Huxham M., Hendriks I.E., Krause-Jensen D., Laffoley D., Luisetti T., Marbà N., Masque P., McGlathery K.J., Megonigal J.P., Murdiyarso D., Russell B.D., Santos R., Serrano O., Silliman B.R., Watanabe K. \& Duarte C.M. 2019. The future of Blue Carbon science. Nature Communications. 10: 3998. DOI: https://doi.org/10.1038/s41467-019-11693-w.

Mann R., Southworth M.J., Harding J.M. \& Wesson J.A. 2009. Population studies of the native eastern oyster, Crassostrea virginica (Gmelin, 1791), in the James River, Virginia, USA. Journal of Shellfish Research. 28: 193-220. DOI: https://doi.org/10.2983/035.028.0203.

Marean C.W. \& Assefa Z. 2005. The middle and upper Pleistocene African record for the biological and behavioral origins of modern humans. In: African Archaeology: A Critical Introduction, (ed. A.B. Stahl). Pp. 93-129. New York, USA and Oxford, UK: Blackwell Studies in Global Archaeology Series. Pp. 490. ISBN: 9781405101561.

Marean C.W., Bar-Matthews M., Bernatchez J., Fisher E., Goldberg P., Herries A.I.R., Jacobs Z., Jerardino A., Karkanas P., Minichillo T., Nilssen P.J., Thompson E., Watts I. \& Williams H.M. 2007. Early human use of marine resources and pigment in South Africa during the Middle Pleistocene. Nature. 449: 905-908. DOI: https://doi.org/10.1038/nature06204.

McBrearty S. \& Brooks A.S. 2000. The revolution that wasn't: a new interpretation of the origin of modern human behavior. Journal of Human Evolution. 39: 453-563. DOI: https://doi.org/10.1006/ihev.2000.0435.

Mclntosh C. 2016. Clam garden governance in the Gulf Islands National Park Reserve. MA (Environment and Management) Thesis, Faculty of Social and Applied Sciences, Royal Roads University, Victoria, BC, Canada. URL: http://hdl.handle.net/10170/960.

McMurray P. 2018. The Oyster Companion: A Field Guide. Ontario, Canada: Firefly Books Ltd. 256 pp. ISBN: 9780228101581.

Micha J.-C. \& Chavez M. 1997. Development of agro-piscicultural ecosystems in tropical marshlands. In: Integrated Fish Farming, (eds J.A. Mathias, A.T. Charles \& H. Baotong), pp. 347-358. Boca Raton: CRC Press. URL: https://www.researchgate.net.

Milner N. 2009. 3.12 Mesolithic middens and marine molluscs, procurement and consumption of shellfish at the site of Sand. In: Section 3 of Scotland's first settlers. Scottish Archaeological Internet Reports, 31: 384-400. URL: http://journals.socantscot.org/index.php/sair/article/view/2067. 
Moheimani N.R. \& Borowitzka M.A. 2006. The long-term culture of the coccolithophore Pleurochrysis carterae (Haptophyta) in outdoor raceway ponds. Journal of Applied Phycology. 18: 703-712. DOI: https://doi.org/10.1007/s10811-006-9075-1.

Moore D. 2020. A biotechnological expansion of shellfish cultivation could permanently remove carbon dioxide from the atmosphere/Una ampliación biotecnológica del cultivo de moluscos bivalvos podría eliminar permanentemente el dióxido de carbono de la atmósfera. Mexican Journal of Biotechnology, 5: 1-10. DOI: https://doi.org/10.29267/mxjb.2020.5.1.1.

Moore D. 2021. Saving the Planet with Appropriate Biotechnology: 4. Coccolithophore cultivation and deployment/Salvando el planeta con biotecnología apropiada: 4. Cultivo de cocolitóforos e implementación. Mexican Journal of Biotechnology. 6 (1):129-155. DOI: https://doi.org/10.29267/mxjb.2021.6.1.129.

Moore D., Heilweck M. \& Petros, P. 2021. Saving the Planet with Appropriate Biotechnology: 1. Diagnosing the Problems/Salvando el planeta con biotecnología apropiada: 1. Diagnóstico de los problemas. Mexican Journal of Biotechnology. 6(1): 1-30. DOI: https://doi.org/10.29267/mxib.2021.6.1.1.

Moore D., Robson G.D. \& Trinci A.P.J. 2020. 21st Century Guidebook to Fungi, second edition. Cambridge University Press. London, UK. pp 600. ISBN: 9781108745680. URL: https://www.cambridge.org/.

Morris J.P. 2019. Report synthesising the existing and potential uses of shells as by-products of the aquaculture industry. A Deliverable from the EU's FP7-funded Marie Curie ITN: CACHE: CAlcium in a CHanging Environment. Open access, DOI: http://doi.org/10.5281/zenodo.2662011.

Morris J.P., Backeljau T. \& Chapelle G. 2019. Shells from aquaculture: a valuable biomaterial, not a nuisance waste product. Reviews in Aquaculture. 11: 42-57. DOI: https://doi.org/10.1111/raq.12225.

Morrison T.H., Adger N., Barnett J., Brown K., Possingham H., \& Hughes T. 2020. Advancing coral reef governance into the Anthropocene. One Earth. 2: 64-74. DOI: https://doi.org/10.1016/j.oneear.2019.12.014.

Munari C., Rossetti E. \& Mistri M. 2013. Shell formation in cultivated bivalves cannot be part of carbon trading systems: a study case with Mytilus galloprovincialis. Marine Environmental Research. 92: 264-267. DOI: https://doi.org/10.1016/j.marenvres.2013.10.006.

Murphy J.N., Schneider C.M., Hawboldt K. \& Kerton F.M. 2020. Hard to soft: biogenic absorbent sponge-like material from waste mussel shells. Matter. in press. DOI: https://doi.org/10.1016/i.matt.2020.09.022.

Myvett G., Haughton M. \& Murray P.A. 2014. Study on the Potential of Fish Farming in the Caribbean. CRFM Technical \& Advisory Document No 2014/2. Belize: Published by the Caribbean Regional Fisheries Mechanism Secretariat. 78 pp. ISSN: 19951132. URL: https://brusselsbriefings.files.wordpress.com/. 
Nakatani N., Takamori H., Takeda K. \& Sakugawa H. 2009. Transesterification of soybean oil using combusted oyster shell waste as a catalyst. Bioresource Technology. 100: 1510-1513. DOI: https://doi.org/10.1016/i.biortech.2008.09.007.

Nikolić M., Bosch A. \& Alfonso S. 1976. A system for farming the mangrove oyster (Crassostrea rhizophorae Guilding, 1828). Aquaculture. 9: 1-18. DOI: https://doi.org/10.1016/00448486(76)90044-2.

Ninfo A., Ciavola P. \& Billi P. 2018. The Po Delta is restarting progradation: geomorphological evolution based on a 47-years Earth Observation dataset. Scientific Reports. 8: article number: 3457 (open access). DOI: https://doi.org/10.1038/s41598-018-21928-3.

Petit J.R., Jouzel J., Raynaud D., Barkov N.I., Barnola J.-M. and 14 others. 1999. Climate and atmospheric history of the past 420,000 years from the Vostok ice core, Antarctica. Nature. 399: 429-436. DOI: https://doi.org/10.1038/20859.

Phillipson D. 2005. The emergence of humankind in Africa. In: African Archaeology, (3rd ed.). Cambridge, UK: Cambridge University Press. ISBN: 9780511800313. Book DOI: https://doi.org/10.1017/CBO9780511800313. Chapter 3, pp. 15-51, DOI: https://doi.org/10.1017/CB09780511800313.003.

Potasman I., Paz A. \& Odeh M. 2002. Infectious outbreaks associated with bivalve shellfish consumption: a worldwide perspective. Clinical Infectious Diseases. 35: 921-928. DOI: https://doi.org/10.1086/342330.

Rana K. 1997. Recent developments in aquaculture statistics. In: Fishery and Aquaculture Statistics in Asia: Proceedings of the FAO/SEAFDEC Regional Workshop on Fishery Statistics, Bangkok, Thailand, 19-21 August 1997: Vol. II. Fishery and Aquaculture Statistical Systems and Programs, pp. 242-254. Bangkok, Thailand: Secretariat, Southeast Asian Fisheries Development Center. Rome: FAO. URL: http://repository.seafdec.org/.

Rasmussen R.S. \& Morrissey M.T. 2007. Biotechnology in aquaculture: transgenics and polyploidy. Comprehensive Food Science and Food Safety. 6: 2-16. DOI: https://doi.org/10.1111/i.1541-4337.2007.00013.x.

Ray N.E., Maguire T.J., Al-Haj A.N., Henning M.C. \& Fulweiler R.W. 2019. Low greenhouse gas emissions from oyster aquaculture. Environmental Science \& Technology. 53: 9118-9127. DOI: https://doi.org/10.1021/acs.est.9b02965.

Robert R. \& Gérard A. 1999. Bivalve hatchery technology: The current situation for the Pacific oyster Crassostrea gigas and the scallop Pecten maximus in France. Aquatic Living Resources. 12: 121-130. DOI: https://doi.org/10.1016/S0990-7440(99)80021-7.

Ruddle K. \& Zhong G. 1988. Integrated Agriculture-Aquaculture in South China. The Dike-Pond System of the Zhujiang Delta. Cambridge, UK: Cambridge University Press. 192 pp. ISBN: 9780521341936. URL: https://www.researchgate.net/

Safamehr A., Langille M.L., Anderson D.M. \& Maclsaac J.L. 2013. Evaluation of composition and in vitro solubility rate of by-products of the Atlantic shellfish industry as alternative calcium sources. Journal of Applied Poultry Research. 22: 529-538. DOI: https://doi.org/10.3382/japr.2013-00752. 
Sahrhage D. \& Lundbeck J. 1992. A History of Fishing. Berlin, Heidelberg: Springer-Verlag. 348 pp. ISBN: 9783642774133. DOI: https://doi.org/10.1007/978-3-642-77411-9.

Salem A.M. \& Saleh M.A. 2010. National Aquaculture Sector Overview. Egypt. In: National Aquaculture Sector Overview Fact Sheets (2003-2020). Rome: FAO Fisheries Division, FAO. URL: http://www.fao.org/fishery/countrysector/naso egypt/en.

Sanger D. \& Elson-Sanger M.J. 1986. Boom and bust on the river: the story of the Damariscotta oyster shell heaps. Archaeology of Eastern North America. 14: 65-78. DOI: http://www.jstor.org/stable/40914267.

Schmidt-Roach S., Duarte C.M., Hauser C.A.E. \& Aranda M. 2020. Beyond reef restoration: next-generation techniques for coral gardening, landscaping, and outreach. Frontiers in Marine Science. 7: article 672. Open accesss. DOI: https://doi.org/10.3389/fmars.2020.00672.

Seed R. 1968. Factors influencing shell shape in the mussel Mytilus edulis. Journal of the Marine Biological Association of the United Kingdom. 48: 561-584. DOI: https://doi.org/10.1017/S0025315400019159.

Seed R. 1980. Shell growth and form in the Bivalvia. In: Skeletal Growth of Aquatic Organisms: Biological Records of Environmental Change, (ed D.C. Rhoads). Pp. 23-68. New York: Springer Science+Business Media. 750 pp. ISBN 9780306402593.

Shamshina J.L., Berton P. \& Rogers R.D. 2019. Chitin as a resource for eco-friendly bioplastics. In: Encyclopedia of Ionic Liquids, (ed. S. Zhang). Singapore: Springer Nature Switzerland AG. ISBN: 9789811067396. Chapter DOI: https://doi.org/10.1007/978-981-10-6739-6 43-1.

Smaal A., Ferreira J., Grant J., Petersen J. \& Strand Ø. (eds). 2019. Goods and Services of Marine Bivalves. Springer Nature. Cham, Switzerland. 591 pp. Open access: https://link.springer.com/book/10.1007/978-3-319-96776-9.

Smith D. 2015. Oyster: A Gastronomic History (with Recipes). London: Abrams \& Chronicle Books. 256 pp. ISBN: 9781419719226.

Smith N.F., Lepofsky D., Toniello G., Holmes K., Wilson L., Neudorf C.M. \& Roberts C. 2019. 3500 years of shellfish mariculture on the Northwest Coast of North America. PLoS ONE. 14: article e0211194. DOI: https://doi.org/10.1371/journal.pone.0211194.

Soo P. \& Todd P.A. 2014. The behaviour of giant clams (Bivalvia: Cardiidae: Tridacninae). Marine Biology. 161: 2699-2717. Open access. DOI: https://doi.org/10.1007/s00227-014-2545$\underline{0}$.

Srinivasa P.C. \& Tharanathan R.N. 2007. Chitin/Chitosan - safe, ecofriendly packaging materials with multiple potential uses. Food Reviews International. 23: 53-72. DOI: https://doi.org/10.1080/87559120600998163.

Stoner A.W. 2019. Forty years of field and laboratory experiments with hatchery-reared Queen Conch: the case for conserving natural stocks. Reviews in Fisheries Science \& Aquaculture. 27: 490-516. DOI: https://doi.org/10.1080/23308249.2019.1628705. 
Syukri bin Othman A., Goh G.H. \& Todd P.A. 2010. The distribution and status of giant clams (family Tridacnidae) - a short review. The Raffles Bulletin of Zoology. 58: 103-111. Published by the National University of Singapore, open accesss. URL: https://lkcnhm. nus.edu.sg/.

Tamburini E., Turolla E., Fano E.A. \& Castaldelli G. 2020. Sustainability of Mussel (Mytilus galloprovincialis) farming in the Po River Delta, Northern Italy, based on a life cycle assessment approach. Sustainability. 12: article number 3814. DOI: https://doi.org/10.3390/su12093814.

Tassanakajon A., Vatanavicharn T., Supungul P., Tang S., Amparyup P., Somboonwiwat K., Tharntada S., Takahashi J. \& Toyohara H. 2008. Biotechnology of marine invertebrates advances in shrimp and shellfish. In: Fisheries for Global Welfare and Environment, 5th World Fisheries Congress 2008 (ed Tsukamoto, K., Kawamura, T., Takeuchi, T., Beard, T.D. Jr. \& Kaiser, M.J.), pp. 221-239. TERRAPUB: Tokyo, Japan. http://www.terrapub.co.jp/.

Teitelbaum A. \& Friedman K. 2008. Successes and failures in reintroducing giant clams in the Indo-Pacific region. SPC Trochus Information Bulletin \#14, July 2008. Published by the Pacific Community (SPC). URL: https://pdfs.semanticscholar.org/.

Telesca L., Michalek K., Sanders T., Peck L.S., Thyrring J. \& Harper E.M. 2018. Blue mussel shell shape plasticity and natural environments: a quantitative approach. Scientific Reports. 8: article 2865. DOI: https://doi.org/10.1038/s41598-018-20122-9.

Toniello G., Lepofsky D., Lertzman-Lepofsky G., Salomon A.K. \& Rowell K. 2019. 11,500 y of human-clam relationships provide long-term context for intertidal management in the Salish Sea, British Columbia. Proceedings of the National Academy of Sciences of the United States of America. 116: 22106-22114. DOI: https://doi.org/10.1073/pnas.1905921116.

Tudge C. 1998 Neanderthals, Bandits and Farmers. How Agriculture Really Began (Darwinism Today series). London: Weidenfield \& Nicolson, an imprint of the Orion Publishing Group. Pp. 64. ISBN: 9780297842583.

Utting S.D. \& Spencer B.E. 1991. The Hatchery Culture of Bivalve Mollusc Larvae and Juveniles. Laboratory Leaflet Number 68. Pp. 32. Lowestoft, UK: Ministry of Agriculture, Fisheries and Food, Directorate of Fisheries Research. Download PDF: https://www.cefas.co.uk/.

Valladão G.M.R., Gallani S.U. \& Pilarski F. 2018. South American fish for continental aquaculture. Reviews in Aquaculture. 10: 351-369. DOI: https://doi.org/10.1111/raq.12164.

Vanhaeren M., d'Errico F., Stringer C., James S.L., Todd J.A. \& Mienis H.K. 2006. Middle Paleolithic shell beads in Israel and Algeria. Science. 312: 1785-1788. DOI: https://doi.org/10.1126/science.1128139.

Veeragurunathan V., Prasad K., Malar V.J., Singh N., Meena R. \& Mantri V.A. 2019. Gracilaria debilis cultivation, agar characterization and economics: bringing new species in the ambit of commercial farming in India. Journal of Applied Phycology. 31: 2609-2621. DOI: https://doi.org/10.1007/s10811-019-01775-z.

Walter R.C., Buffler R.T., Bruggemann J.H., Guillaume M.M,, Berhe S.M., Negassi B., Libsekal Y., Cheng H., Edwards R.L., von Cosel R., Néraudeau D. \& Gagnon M. 2000. Early human 
occupation of the Red Sea coast of Eritrea during the last interglacial. Nature. 405: 65-69. DOI: https://doi.org/10.1038/35011048.

Wells S. 1996. Hippopus hippopus. The IUCN Red List of Threatened Species. IUCN, 1996: article number e.T10105A3164917. DOI https://www.iucnredlist.org/species/10105/3164917.

Wickins J.F. \& Lee D.O'C. 2002. Crustacean Farming: Ranching and Culture, 2nd Edition. Pp. 464. Oxford, UK: Blackwell Science Ltd. ISBN: 9780632054640. URL: https://epdf.pub/crustacean-farming-ranching-and-culture.html.

Wisaijorn W., Poo-arporn Y., Marin P., Ordóňez S., Assabumrungrat S., Praserthdam P., Saebea D. \& Soisuwan S. 2017. Reduction of carbon dioxide via catalytic hydrogenation over copper-based catalysts modified by oyster shell-derived calcium oxide. Journal of Environmental Chemical Engineering. 5: 3115-3121. DOI: https://doi.org/10.1016/j.jece.2017.06.018.

Wyatt G.J. 2015. Sea level change in the Gulf Islands National Park Reserve, southern British Columbia: implications for the interpretation of nearshore archaeological features. MSc (Environment and Management) Thesis. Faculty of Social and Applied Sciences, Royal Roads University, Victoria, BC, Canada. URL: http://hdl.handle.net/10170/862.

Xiang J. 2015. Recent major advances of biotechnology and sustainable aquaculture in China. $\begin{array}{llll}\text { Current } & \text { Biotechnology. 296-310. }\end{array}$ https://doi.org/10.2174/2211550105666151105190012.

Yang H. 1994. Integrated fish farming. In: Freshwater Fish Culture in China: Principles and Practice, (ed S. Li \& J. Mathias). Pp. 219-270. (Developments in Aquaculture and Fisheries Science, vol 28), 450 pp. Amsterdam: Elsevier. ISBN: 9780444888822.

Yang H.-L., Lin H-Y. \& Lin C.-C. 2014. The search for sustainable grouper farming. Global Aquaculture Advocate, January 2014. URL: https://www.aquaculturealliance.org/.

Ysebaert T., Walles B., Haner J. \& Hancock B. 2019. Habitat modification and coastal protection by ecosystem-engineering reef-building bivalves. In: Goods and Services of Marine Bivalves, (ed. A. Smaal, J. Ferreira, J. Grant, J. Petersen \& Ø. Strand). Cham, Switzerland: Springer Nature Switzerland AG. ISBN: 9783319967752. Chapter DOI: https://doi.org/10.1007/978-3319-96776-9 13 